US Army Corps

of Engineers ${ }_{\circledast}$

Engineer Research and

Development Center

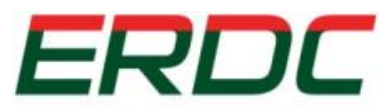

INNOVATIVE SOLUTIONS for a safer, better world

Aquatic Nuisance Species Research Program

\title{
Incidence of Zebra Mussel on U.S. Army Corps of Engineers Structures
}

K. James Hay, Irene E. MacAllister, Rebekah C. Wilson, January 2020 and Abigail M. Brake

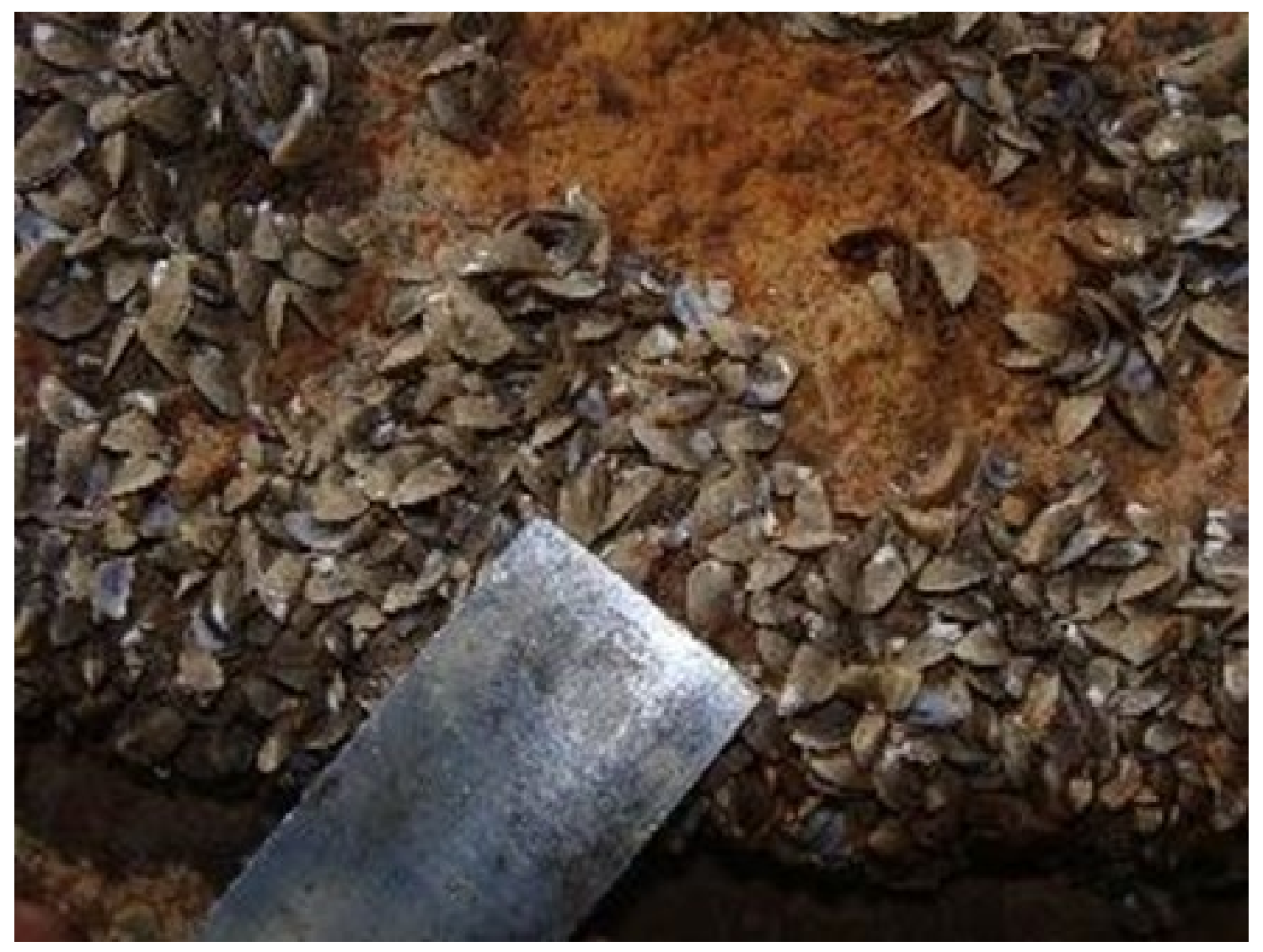


The U.S. Army Engineer Research and Development Center (ERDC) solves the nation's toughest engineering and environmental challenges. ERDC develops innovative solutions in civil and military engineering, geospatial sciences, water resources, and environmental sciences for the Army, the Department of Defense, civilian agencies, and our nation's public good. Find out more at www.erdc.usace.army.mil.

To search for other technical reports published by ERDC, visit the ERDC online library at http://acwc.sdp.sirsi.net/client/default. 


\section{Incidence of Zebra Mussel on U.S. Army Corps of Engineers Structures}

K. James Hay, Irene E. MacAllister, Rebekah C. Wilson, and Abigail M. Brake U.S. Army Engineer Research and Development Center (ERDC) Construction Engineering Research Laboratory (CERL) 2902 Newmark Dr.

Champaign, IL 61824

Final Technical Report (TR)

Approved for public release; distribution is unlimited.

Prepared for Headquarters, U.S. Army Corps of Engineers

Washington, DC 20314-1000

Under Funding Account Code 96 x 3123; AMSCO Code 008284 


\section{Abstract}

Zebra mussels (Dreissena polymorpha) are invasive/nuisance species first introduced into the Great Lakes region in the late 1980s. Since their introduction efforts have been underway to prevent and/or control their spread. Zebra mussel infestations can occur on submerged critical structure. For the U.S. Army Corps of Engineers (USACE) it is essential that hydraulic infrastructure are effectively and efficiently maintained to ensure proper water control and navigation. A study was conducted to determine the extent of the zebra mussel invasion on USACE districts and the impact zebra mussels have on USACE infrastructure. Consistent with available U.S. Geological Survey (USGS) data, it was found that zebra mussels are present within 24 of the 36 continental United States USACE district boundaries, although San Francisco and Galveston Districts have only isolated populations in non-USACE waters. Albuquerque and Omaha Districts appear to be the two districts most at risk for invasion. While infestations are common, $62 \%$ of the districts with USACE infested waters reported no or minimal impacts on the infrastructure or operation/maintenance costs. Those districts with impacts did not normally have cost figures readily available. It was also found that 12 districts have or have had zebra mussel monitoring programs in place.

DISCLAIMER: The contents of this report are not to be used for advertising, publication, or promotional purposes. Citation of trade names does not constitute an official endorsement or approval of the use of such commercial products. All product names and trademarks cited are the property of their respective owners. The findings of this report are not to be construed as an official Department of the Army position unless so designated by other authorized documents. 


\section{Contents}

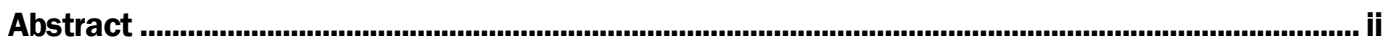

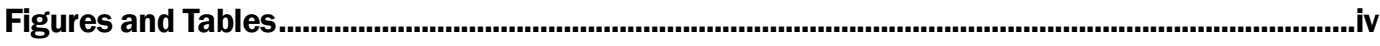

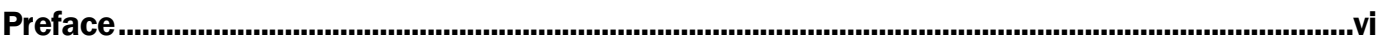

1 Introduction ................................................................................................................................ 1

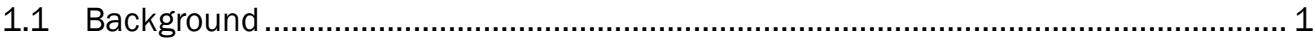

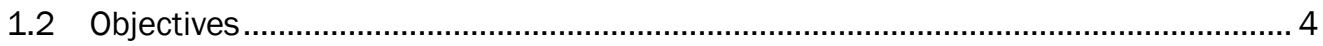

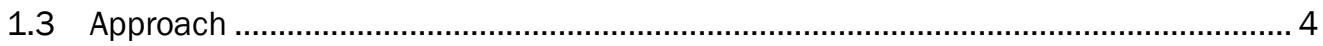

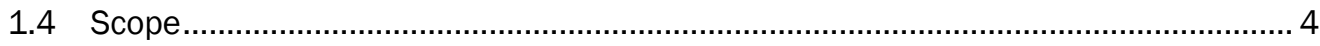

2 Methods .................................................................................................................................................. 5

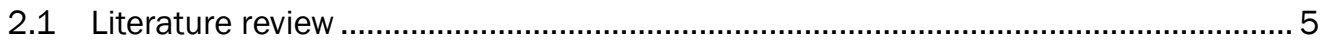

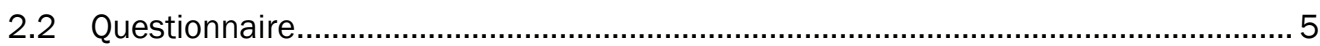

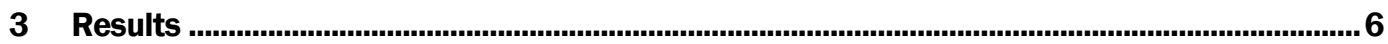

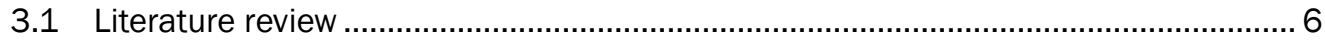

3.2 Questionnaire results ................................................................................ 11

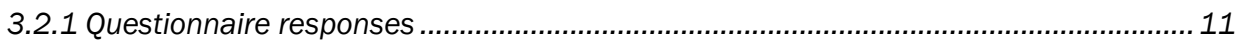

3.2.2 Mussel occurrence on Corps Infrastructure .............................................................. 11

3.2.3 Impacts of Mussels on Corps Infrastructure ............................................................ 13

4 Discussion …...........................................................................................................................................18

4.1 Mussel occurrence on Corps infrastructure ......................................................... 18

4.2 Extent of mussel impacts at Corps Infrastructure .................................................20

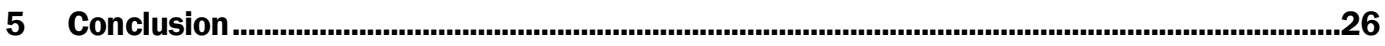

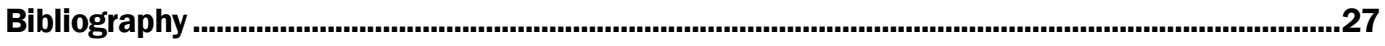

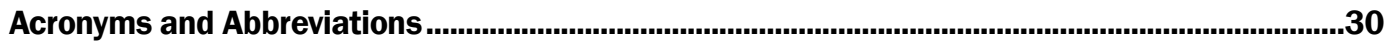

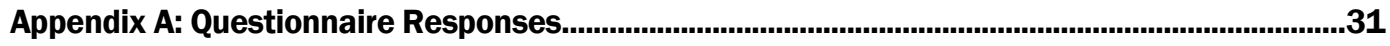

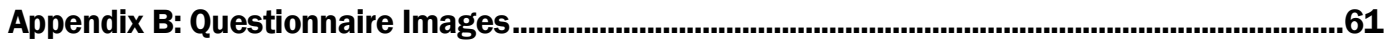

Appendix C: Invasive Species Leadership Team Document........................................................64

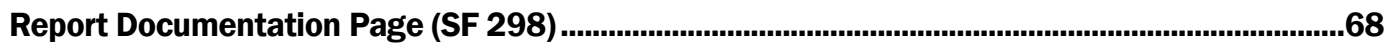




\section{Figures and Tables}

\section{Figures}

1 Zebra Mussels on sector gates at T.J. O’Brian Lock \& Dam, Rock Island

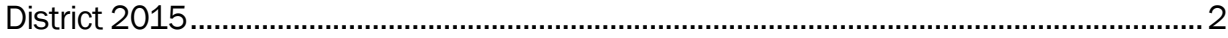

2 Zebra Mussels on emergency bulkheads at Emsworth Lock \& Dam, Pittsburgh District 2016 ..............................................................................................

3 Severe pitting corrosion of bulkheads at Pittsburgh District before (left) and after (right) removal of Zebra mussel encrustation.................................................. 3

4 Point distribution map of Dreissena polymorpha throughout CONUS

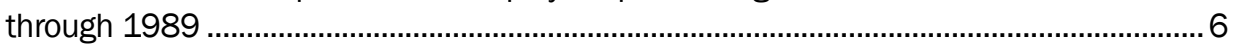

5 Point distribution map of Dreissena polymorpha throughout CONUS

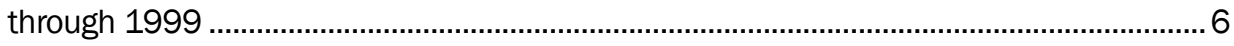

6 Point distribution map of Dreissena polymorpha throughout CONUS

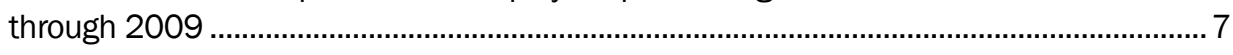

7 Point distribution map of Dreissena polymorpha throughout CONUS through February 2019 .................................................................................................... 7

8 USACE districts with a zebra mussel presence within district boundaries, shading represents a presence .....................................................................................19

9 USGS database representation of zebra mussel observations .....................................19

10 Zebra mussels on Montgomery aluminum bulkhead (image 1)......................................23

11 Zebra mussels on Montgomery aluminum bulkhead (image 2).....................................23

12 Montgomery aluminum bulkhead after power washing .................................................24

13 Montgomery aluminum bulkhead after power washing (closeup) .................................24

B-1 ZM on concrete in lock chamber of \#3 Lock \& Dam on Red River, April 2017, Vicksburg District.

B-2 ZM on concrete wall in lock chamber of \#3 Lock \& Dam on Red River, April 2017, Vicksburg District.

B-3 ZM attached to ACM (articulated concrete mat), September 2012, Memphis District.

B-4 Inspection gallery - Lake side of the dam after flood waters receded in 2015, Little Rock District.

B-5 Lead Hill Park boat ramp 2015, Little Rock District......................................................63

\section{Tables}

1 Summarized district responses regarding presence of zebra mussels ...........................11

2 Summarized district response regarding impacts of zebra mussels ..............................14

3 Facilities/structures likely to be affected by zebra mussels (Miller and

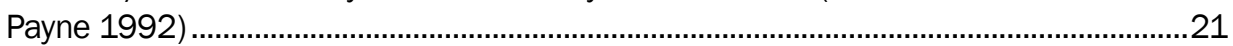

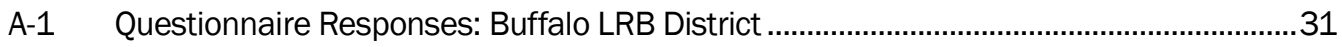

A-2 Questionnaire Responses: Chicago LRC District...........................................................32

A-3 Questionnaire Responses: Huntington LRH District .......................................................34 
A-4 Questionnaire Responses: Louisville LRL District ..........................................................35

A-5 Questionnaire Responses: Nashville LRN District.............................................................36

A-6 Questionnaire Responses: Pittsburgh LRP District ..........................................................37

A-7 Questionnaire Responses: Memphis MVM District ..........................................................38

A-8 Questionnaire Responses: New Orleans MVN District ........................................................39

A-9 Questionnaire Responses: Rock Island MVR District .......................................................40

A-10 Questionnaire Responses: St. Paul MVP District............................................................ 41

A-11 Questionnaire Responses: Vicksburg MVH District.........................................................42

A-12 Questionnaire Responses: Baltimore NAB District ..........................................................43

A-13 Questionnaire Responses: New England NAE District.....................................................44

A-14 Questionnaire Responses: New York NAN District.............................................................45

A-15 Questionnaire Responses: Norfolk NAO District.............................................................46

A-16 Questionnaire Responses: Philadelphia NAP District....................................................... 47

A-17 Questionnaire Responses: Kansas City NWK District......................................................48

A-18 Questionnaire Responses: Omaha NWO District ........................................................49

A-19 Questionnaire Responses: Portland NWP District.........................................................50

A-20 Questionnaire Responses: Charleston SAC, Savannah SAS, and Wilmington SAW Districts....................................................................................................51

A-21 Questionnaire Responses: Mobile SAM District ..............................................................52

A-22 Questionnaire Responses: Albuquerque SPA Division ……………………….................53

A-23 Questionnaire Responses: Los Angeles SPL District .......................................................54

A-24 Questionnaire Responses: Sacramento SPK District .....................................................55

A-25 Questionnaire Responses: San Francisco SPN District.................................................55

A-26 Questionnaire Responses: Fort Worth SWF District.......................................................56

A-27 Questionnaire Responses: Galveston SWG District ......................................................57

A-28 Questionnaire Responses: Little Rock SWL District.......................................................58

A-29 Questionnaire Responses: Tulsa SWT District ..............................................................59 


\section{Preface}

This study was conducted for the Aquatic Nuisance Species Research Program (ANSRP) via Funding Account Code 96 x 3123; AMSCO Code 008284. The ANSRP is sponsored by Headquarters, U.S. Army Corps of Engineers (HQUSACE) and is assigned to the U.S. Army Engineer Research and Development Center (ERDC) under the purview of the Environmental Laboratory (EL). Dr. Linda Nelson was the ANSRP Program Manager; Dr. Alfred Cofrancesco was Technical Director, Environmental Engineering and Sciences.

The work was performed by the Environmental Processes Branch, of the Installation Division; and the Materials Branch, of the Facilities Division, U.S. Army Engineer Research and Development Center, Construction Engineering Research Laboratory (ERDC-CERL). At the time of publication, Dr. George Calfas was Chief of the Environmental Processes Branch and Vicki VanBlaricum was Chief of the Materials Branch; Michelle Hanson was Chief of the Installation Division and Dr. Christa M. Woodley was Acting Chief of the Facilities Division. The Deputy Director of ERDC-CERL was Dr. Kirankumar V. Topudurti and the Director was Dr. Lance D. Hansen.

COL Teresa A. Schlosser was Commander of ERDC, and Dr. David W. Pittman was the Director. 


\section{Introduction}

\subsection{Background}

Zebra mussels, Dreissena polymorpha, and quagga mussels, Dreissena rostriformis bugensis, are invasive/nuisance species first introduced into the Great Lakes region in the late 1980 os (Benson 2014). Since their introduction into North American waters, efforts by various agencies (Invasive Mussel Collaborative 2018) such as the U.S. Geological Survey, U.S. Department of Energy, U.S Department of Interior - Bureau of Reclamation, U.S. Fish and Wildlife Service, and the U.S. Army Corps of Engineers (USACE), have been underway to prevent and/or control the spread of dreissenid mussels (Mayer 2008).

Dreissenid mussels are bivalve mollusks that can attach to most firm substrates. Zebra mussels can filter approximately one liter per day which reduces the phytoplankton resulting in increased water clarity and changes in the ecological structure, promoting algae growth and threaten native fish and mussels (Invasive Mussel Collaborative 2018). Dreissenid mussels can spread via three mechanisms: (1) their larvae (veligers) can drift within bodies of waters, (2) the veligers can be transported by various means such as bilge water and waterfowl, and (3) the mussels can attach to surfaces that are moved from one body of water to another such as via boat hulls, sea planes and buoys (MassWildlife 2019). Furthermore, female zebra mussels are prolific and can produce up to 1 million eggs per year. All of the aforementioned have contributed to the spread of dreissenid mussels throughout reservoirs and waterways.

The USACE Navigation mission operates and maintains about 25,000 miles of waterways and channels, 191 lock locations on 41 waterways, and 926 coastal, Great Lakes and inland harbors (USACE 2018). It is essential that hydraulic structures (HSs) are effectively and efficiently maintained to ensure proper water control and navigation, as USACE inland waterways handle over $\$ 70$ billion worth of consumer goods annually and $48 \%$ of the $\$ 2$ trillion in U.S. marine transportation industry commerce passes through USACE maintained harbors (USACE 2017). 
The USACE Dam Safety Program operates and maintains approximately 700 dams that provide benefits such as flood risk management, hydropower, water supply, navigation, and recreation. There are more than 400 USACE recreational lakes and river projects (USACE 2019a).

Infestations of zebra and quagga mussels can occur on submerged critical structures such as water intake pipes, water filtration and electric generating plants (Figures 1 and 2). It has been estimated that the United States incurs $\$ 1$ billion per year in damages and control costs associated with management and mitigation due to zebra mussels (Pimentel et. al. 2005). Studies show that mussel adhesion may also accelerate corrosion on uncoated structures, leading to additional concerns on long-term impacts of bio-adhering species (Tennessee Aquatic Nuisance Species Task Force 2008; U.S. Army Corps of Engineers 1992, 1994, 1998) as shown in Figure 3.

Figure 1. Zebra Mussels on sector gates at T.J. O'Brian Lock \& Dam, Rock Island District 2015.

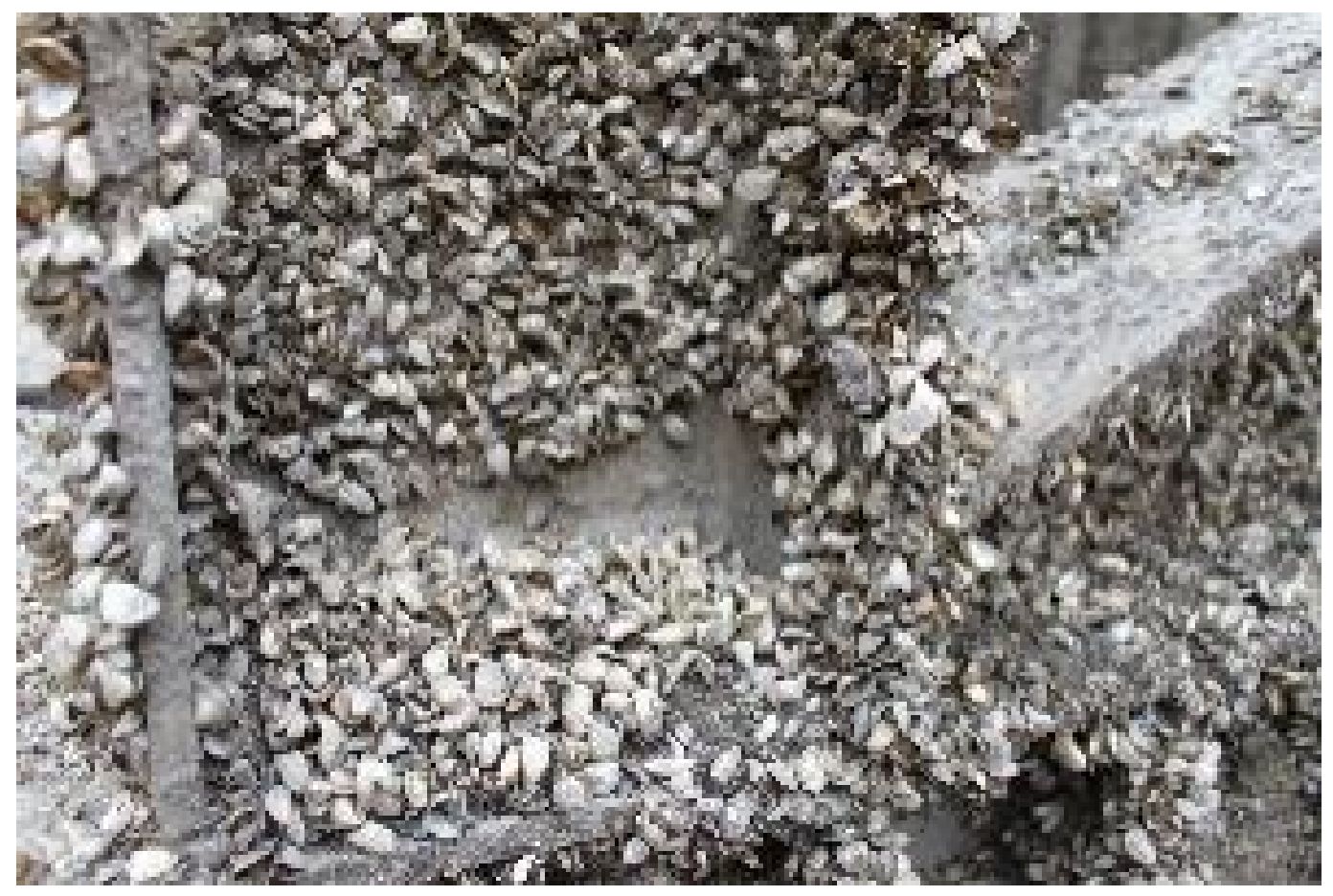


Figure 2. Zebra Mussels on emergency bulkheads at Emsworth Lock \& Dam, Pittsburgh District 2016.

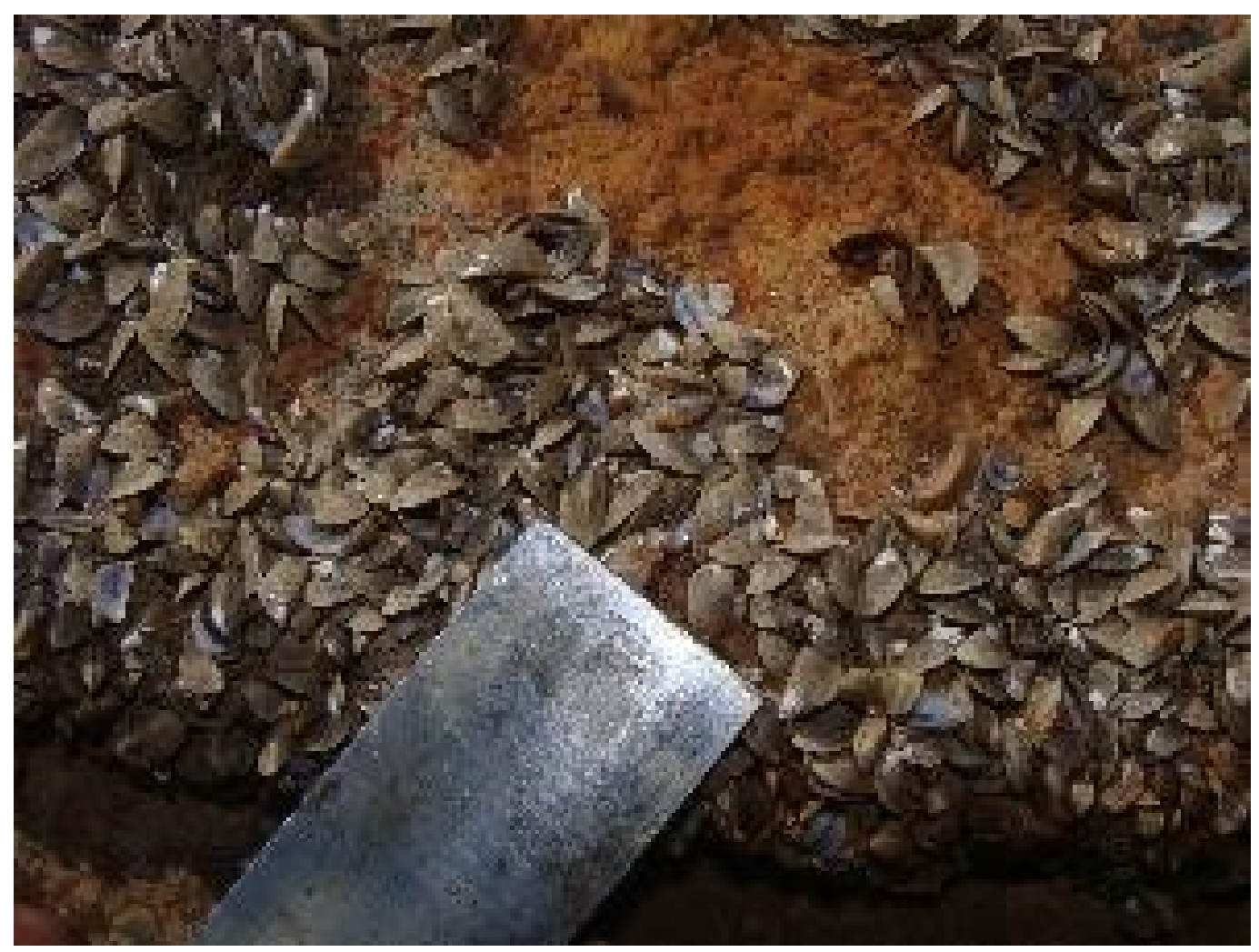

Figure 3. Severe pitting corrosion of bulkheads at Pittsburgh District before (left) and after (right) removal of Zebra mussel encrustation.
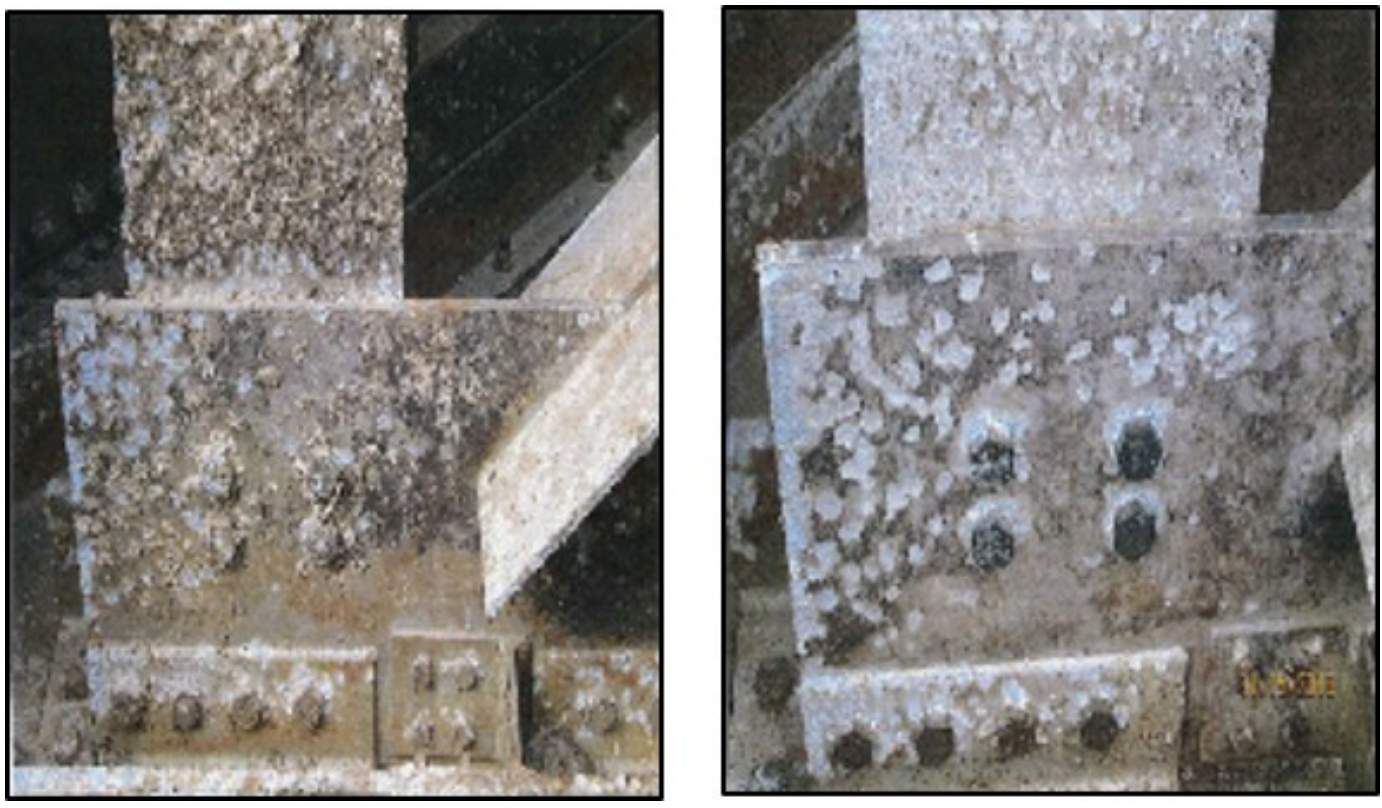


\subsection{Objectives}

The object of this work was to investigate and determine (1) the current status of the zebra mussel invasion on USACE districts, and (2) the economic and structural impacts zebra mussels have on USACE infrastructure.

\subsection{Approach}

The study was conducted using currently available resources including scientific (and gray) literature, web-based information (including electronic databases) as well as by gathering information through informally administered personal questionnaires.

\subsection{Scope}

This study discusses the extent and impact of zebra mussels on U.S. Army Corps infrastructure throughout the continental United States (CONUS). This includes seven divisions and 36 districts. 


\section{Methods}

\subsection{Literature review}

A review of scientific as well as gray literature was conducted to help determine the extent of mussel infestations affecting USACE infrastructure across all the districts in the continental United States.

\subsection{Questionnaire}

The information sought through the questionnaires includes the presence and location of zebra mussels in each district, the history of infestation, the types of infrastructure affected, the types of infrastructure surfaces infested, the costs associated with zebra mussel mitigation and prevention, and the types of preventative measures taken against zebra mussels. This information was then compiled and analyzed to provide an overview of the extent and impact of zebra mussels on USACE infrastructure.

The questionnaire was developed with input from the project development team (PDT), informal questioning of stakeholders including the U.S Bureau of Reclamation. The latest questionnaire instrument used is included in Appendix A.

A list of appropriate district contacts was developed using a list of personnel on the USACE Invasive Species Leadership Team (ISLT) and the attendee list from the 2018 USACE Lock Maintenance Workshop. Emails were sent out to those contacts and follow up sessions were conducted via phone and/or email depending on the responses. Many of the contacts were helpful and took it upon themselves to aid in collecting information. The lead point of contact (POC) of the ISLT, Damian Walter of the Walla Walla District, sent the questionnaire to all the members of the ISLT. Many of the contacts sent images and reports providing information related to zebra mussel in their districts and/or divisions. The responses to the questionnaire are assembled in Appendix A. Some of the information in the questionnaire responses were provided by the district representative directly and some were inserted by researchers conducting phone interviews or from compiled email responses. 


\section{Results}

\subsection{Literature review}

The following current references (2007 or later) relate to the occurrence and impact of zebra mussels on USACE districts and infrastructure:

USGS - The U.S. Geological Survey (USGS) maintains a database of nonindigenous aquatic species which include data regarding the zebra mussel infestation in the continental United States (USGS 2019). These data are based on reports of confirmed zebra mussel observations. Each observation is referenced for further details. Figures 4 to 7 show the extent and spread of the zebra mussel infestation over the last 33 years.

Figure 4. Point distribution map of Dreissena polymorpha throughout CONUS through 1989.

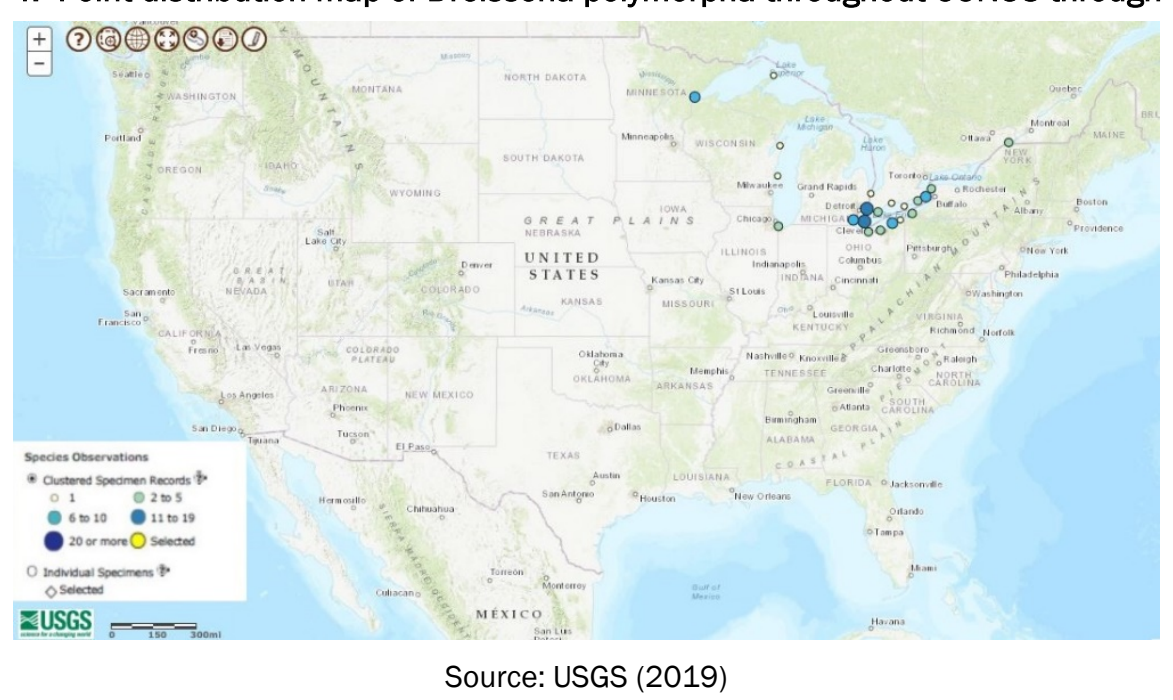

Figure 5. Point distribution map of Dreissena polymorpha throughout CONUS through 1999.

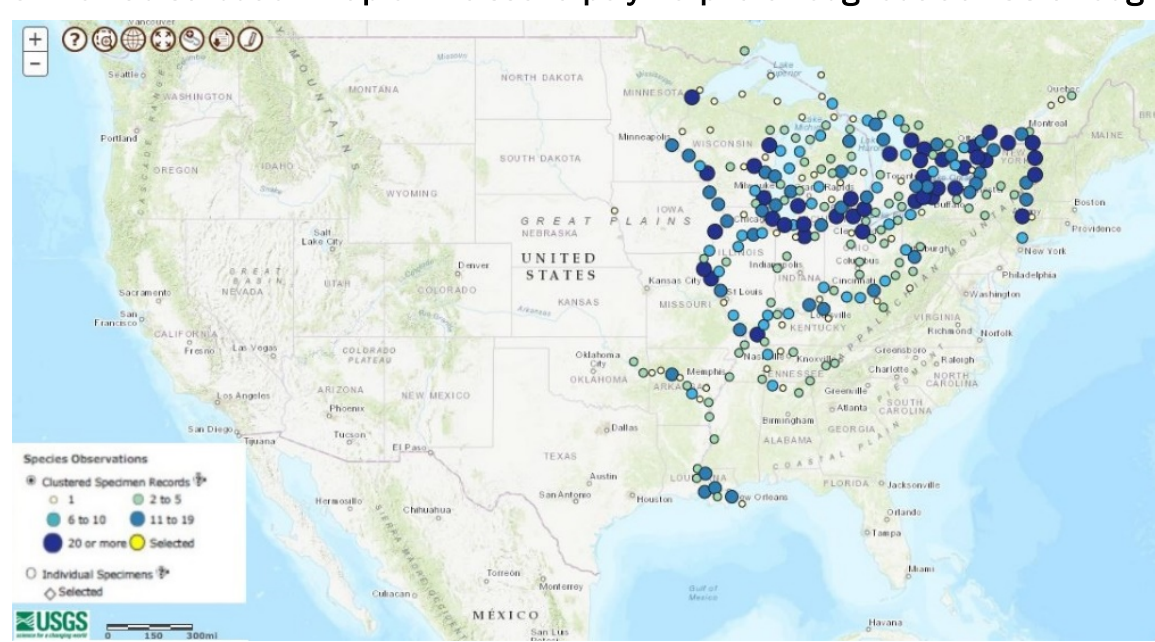

Source: USGS (2019) 
Figure 6. Point distribution map of Dreissena polymorpha throughout CONUS through 2009.

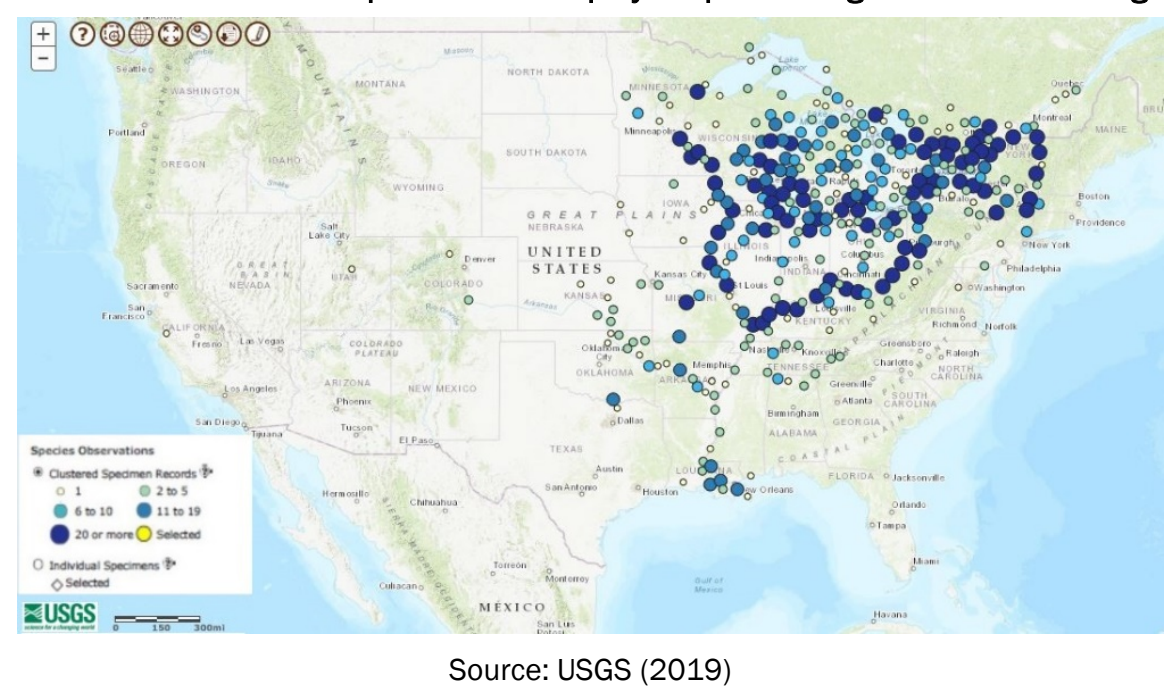

Figure 7. Point distribution map of Dreissena polymorpha throughout CONUS through February 2019.

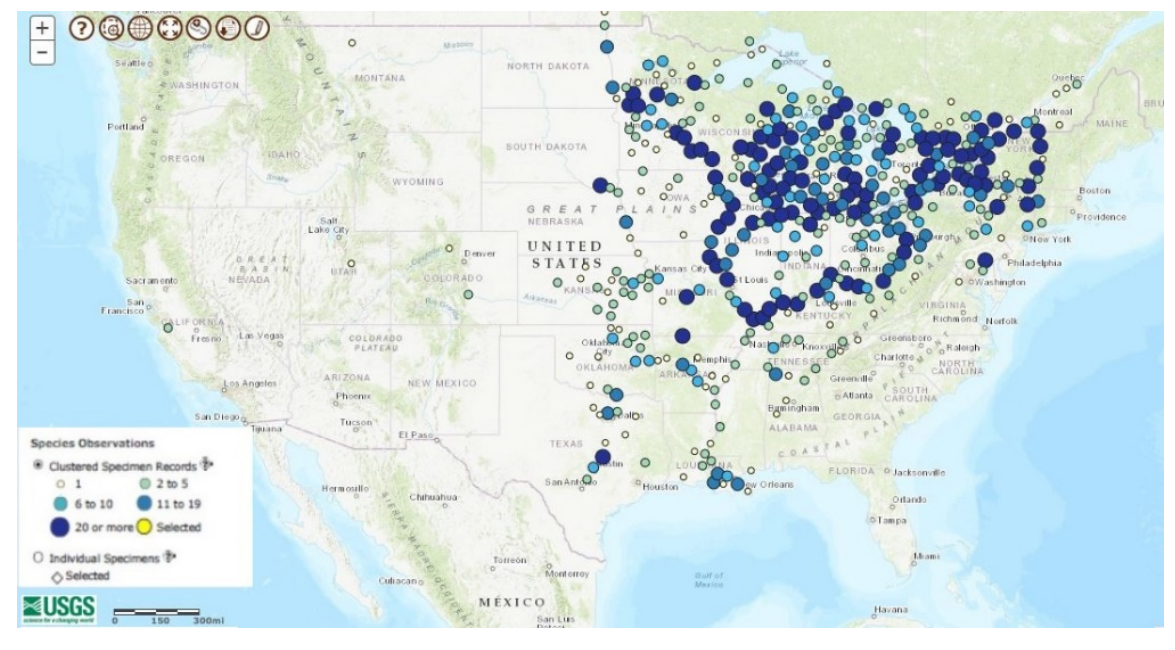

Source: USGS (2019)

Bureau of Reclamation - The Bureau of Reclamation published a report providing an assessment of the impact of invasive mussels on the Fort Randall Dam and Powerplant, which is in the Omaha District and impounds Lake Francis Case on the Missouri River in South Dakota (U.S. Dept. of the Interior 2017). The report's purpose was to provide USACE with an assessment of the vulnerability of the facility to invasive mussel impacts should that infestation occur.

E2 Consulting Engineers, Inc., URS Group, Inc. - A report submitted to the St. Paul District in 2007 titled "Risk Assessment and Decision Analysis Support for Invasive Mussel Management for the St. Croix Basin 
and Adjacent Upper Mississippi River" provides extensive background on the biology, ecology, risk and consequences of establishment, and habitat suitability for invasive mussels.*

USACE, Fort Worth District - The Fort Worth District published a report titled Zebra Mussel Resource Document - Trinity River Basin, Texas (USACE 2013) with the purpose of providing the knowledge for the monitoring, treatment, and anticipated cost of zebra mussels. The document is specific to the Fort Worth District regarding the presence and potential impacts of zebra mussels but also presents background material, such as biology and history, that is applicable anywhere.

Colorado Parks \& Wildlife - A newsletter published by the Colorado Parks \& Wildlife (CPW) Invasive Species Program lists actual past and estimated cost figures for the impact of zebra and quagga mussels in the United States and Canada (CPW 2016). References for all cost figures are provided. The cost figures are organized into three categories: Industrial Facilities, Water Treatment, and Power Generation. There are no references specific to USACE, but a conclusion that can be drawn from the newsletter is that invasive mussels have caused significant Operations and Maintenance (O\&M) costs to multiple facilities. For example, it is estimated that industry spent $\$ 3.1$ billion over 10 years, and the total cost for the Eastern U.S. is $\$ 100$ to $\$ 500$ million per year.

Tulsa District - USACE - Tulsa District released a response plan for the infestation of zebra mussels at Denison Dam. ${ }^{\dagger}$ This report discusses the history and current (2010) state of the infestation as well as potential impacts of the zebra mussels on the Denison Dam infrastructure. Recommendation are also presented for monitoring and preventing extensive damage.

ISLT - In an unpublished document (2018, Appendix C) drafted by ISLT, intended as a letter to Headquarters, U.S. Army Corps of Engineers (HQUSACE) in response to a National Invasive Species Council (NISC) request regarding the impacts of invasive species on USACE, there is discussion that USACE estimates an $\$ 80$ million per year total impact from all

\footnotetext{
* Bartell, S. M., Y. Wu, S. K. Nair, J. Orr, and J. Ragland. 2007. Risk Assessment and Decision Analysis Support for Invasive Mussel Management for the St. Croix Basin and Adjacent Upper Mississippi River. Final Report for the U.S. Corps of Engineers. E2 Consulting Engineers, Inc. and URS Group, Inc., USACE contract number W912ES-05-D-0002 Task Order 07.

† Laney, E. E. 2010. Tulsa District Response Plan for the Infestation of Zebra Mussels (Dreissena polymorpha) at Denison Dam, Lake Texoma, Oklahoma and Texas. USACE Tulsa District, Planning \& Environmental Division, Environmental Compliance and Analysis Branch.
} 
invasive species. This estimate is not broken down by species. It is a concern that the impact to the Corps' infrastructure will be lost time, capacity, and/or capability. A specific example is given regarding the zebra mussel infestation at Gavins Point Dam where reduced hydropower generation and increased downtime were realized. It mentions that the Corps has not done a complete assessment but has rather dealt with each case depending on immediate impact or need. The document then provides examples of efforts the Corps has made toward zebra mussel prevention and treatment but then concludes by writing "in general given constraints on budgets our agency has to react versus prevent."

Bureau of Reclamation - The Bureau of Reclamation published another report providing an assessment of the impact due to invasive mussels on the Hoover, Davis, and Parker Dams (U.S. Department of the Interior 2016). This report specifically addresses quagga mussels but gives recent cost figures for the impacts of mussels on dam facilities.

Norfolk District - An aquatic life assessment for the James River Streambank Stabilization Project ${ }^{*}$ contains an appendix that provides a freshwater mussel survey report. That report claims that there are no zebra mussels in the James River basin (a large part of Norfolk District). It does, however, mention that there has been a reporting of zebra mussels in Prince William County, VA (within the Potomac River Basin), which is in nearby Baltimore District.

Missouri Department of Conservation - An online article regarding zebra mussel control discusses the invasion into Missouri in 1991 (MDC 2018). The article specifically mentions that mussels were first reported in the Mississippi River and then later found in the lower Meramec River (both areas are in the St. Louis District).

Lake Champlain Committee - A web article on the Lake Champlain Committee website discusses invasive species (Lake Champlain Committee 2018). It specifically mentions that zebra mussels entered Lake Champlain around 1993. Lake Champlain is in the New York District.

TPWD News - A news release by Texas Parks \& Wildlife Department (TPWD) presents the information that Lake Georgetown (a USACE lake in Fort

* Norfolk District. 2015. James River Streambank Stabilization Project - Biological Assessment, Essential Fish Habitat Assessment, and Effects to Anadromous Fish. Norfolk, VA: U.S. Army Corps of Engineers (USACE) Norfolk District. 
Worth District) and Lake Livingston (a Trinity River Authority lake in Galveston District) in Texas are infested with zebra mussels (TPWD News 2017).

Gaarder - A news article published in the Omaha World Herald tells of the recent observation of zebra mussels at Cunningham Lake, NE (in Omaha District). It also mentions that they have been present in Lake Zorinsky since 2010 (Gaarder 2018a). The Cunningham and Zorinsky Dams were built by USACE and the lakes are leased to the City of Omaha. A more recent article reports that USACE will drain Cunningham Lake to eradicate two invasive species, zebra mussels and common carp (Gaarder 2018b).

Ducey - A news article on the Omaha World Herald's website www. omaha.com describes the inevitable spread of zebra mussels throughout Nebraska (Ducey 2018). It mentions that the Missouri River is already infested and a number of lakes are also infested or suspect. This includes waters in both the Omaha and Kansas City Districts.

San Justo Reservoir - A news article on the Benito Link Website (benitolink.com) discusses the infestation of zebra mussels on the San Juan Reservoir in San Benito County, CA in 2008 (Biles 2015). The lake is within the boundaries of the San Francisco District, but is operated by the San Benito County Water District (i.e., not a USACE lake). The lake has been under quarantine ever since. Another news article on the same website describes the results of a county board meeting where county and federal officials claimed that it may be years before the reservoir is reopened (Chadwell 2016). Later in 2016, the Bureau of Reclamation published a proof-of-concept report on the eradication of zebra mussels in San Juan Reservoir using potash (O'Meara and Hosler 2016). A final report describing the development of a mussel eradication plan using potash was published in 2018 (USDOI 2018). The plan includes four steps: drawing down the reservoir, applying potash to achieve $100 \mathrm{ppm}$ potassium, holding the treatment for 30 days, and monitoring/evaluating the treatment.

Benson - The first chapter in the book, "Quagga and Zebra Mussels: Biology, Impacts, and Control, 2nd Edition" provides an extremely detailed account of the history of the dreissenid mussel invasion into North America. The author references the year that dreissenids were first sighted in major rivers and discusses their introduction to lakes and infrastructure up until 2010 (Benson 2014). 
North Dakota Game and Fish Department - A news release by the North Dakota State Government indicates that zebra mussels were discovered in Lake Astabula (NDGF 2019). Lake Astabula is a St. Paul District managed lake on the Sheyenne River north of Bald Hill Dam.

South Dakota Game, Fish, and Parks - A news release by the State of South Dakota indicates that zebra mussels were discovered in Lake Sharpe (South Dakota GFP 2019). Lake Sharpe is a USACE Omaha District managed lake on the Missouri River just west of the Big Bend Dam.

\subsection{Questionnaire results}

\subsubsection{Questionnaire responses}

Of the 36 CONUS USACE districts, 28 provided fairly complete responses and seven provided partially complete responses. One district (St. Louis) did not respond. Considering the time needed to answer the questionnaire and to do so voluntarily by a limited number of district representatives, it is reasonable to expect that some information will be missing or possibly inaccurate.

\subsubsection{Mussel occurrence on Corps Infrastructure}

Table 1 lists summarized and edited responses extracted from the questionnaire and literature that describe the extent at which zebra mussels (ZM) are or were present in USACE districts and on USACE infrastructure. The table includes all CONUS districts, including those where answers to the questionnaire were not received or were incomplete. Blank entries in the table indicate a lack of response or the lack of literature, or are not applicable for that particular question. Answers with a footnote indicate that some or all of the answer was obtained from literature.

Table 1. Summarized district responses regarding presence of zebra mussels.

\begin{tabular}{|l|l|l|l|l|}
\hline District & $\begin{array}{c}\text { Office } \\
\text { Symbol }\end{array}$ & $\begin{array}{c}\text { Are ZM Present } \\
\text { Within District } \\
\text { Boundaries? }\end{array}$ & \multicolumn{1}{|c|}{ Extent of Presence on Infrastructure } & History \\
\hline Buffalo & LRB & Yes & $\begin{array}{l}\text { At Black Rock Lock (only infrastructure in district) at } \\
\text { manageable levels. }\end{array}$ & \\
\hline Chicago & LRC & Yes & $\begin{array}{l}\text { Most locations, significant population at Brandon } \\
\text { Lock \& Dam. }\end{array}$ & \\
\hline Detroit & LRE & Yes & $\begin{array}{l}\text { At many projects throughout Lakes Huron, Michigan } \\
\text { \& Erie. More prevalent further south. Numerous } \\
\text { commercial/recreational harbors on each lake note } \\
\text { presence during routine O\&M activities. This typically } \\
\text { includes navigation channels and coastal navigation } \\
\text { structures (breakwaters, piers, revetments). }\end{array}$ & \\
\hline
\end{tabular}




\begin{tabular}{|c|c|c|c|c|}
\hline District & $\begin{array}{l}\text { Office } \\
\text { Symbol }\end{array}$ & $\begin{array}{l}\text { Are ZM Present } \\
\text { Within District } \\
\text { Boundaries? }\end{array}$ & Extent of Presence on Infrastructure & History \\
\hline Huntington & LRH & Yes & $\begin{array}{l}\text { Widespread. They are present at all nine Navigation } \\
\text { projects on the Ohio and Kanawha Rivers as well. No } \\
\text { significant populations have been noted at other } \\
\text { lakes, but they are likely present in low densities }\end{array}$ & $\begin{array}{l}\text { Historically have } \\
\text { been discovered in } \\
\text { high densities at } \\
\text { Alum Creek (1999), } \\
\text { Dewey (2004) and } \\
\text { Fishtrap (2009) } \\
\text { Lakes. Peaked } \\
\text { around } 2007\end{array}$ \\
\hline Louisville & LRL & Yes & $\begin{array}{l}\text { At the Louisville District locks and dams and Ohio } \\
\text { River at Ohio Falls Station }\end{array}$ & \\
\hline Nashville & LRN & Yes & Widespread but population much less now. & $\begin{array}{l}\text { Population peaked } \\
\sim 2001-2002 \text {, as } \\
\text { high as } 23000 / \text { sq. } \\
\mathrm{m} \text { in some areas }\end{array}$ \\
\hline Pittsburgh & LRP & Yes & Widespread. At all navigation dams & $\begin{array}{l}\text { Peaked } \sim 2007 \text {, } \\
\text { population crashed } \\
\sim 2010-11 \text {, now } \\
\text { stabilized }\end{array}$ \\
\hline Memphis & MVM & Yes & Lower Mississippi River and Lower Ohio River & \\
\hline New Orleans & MVN & Yes & $\begin{array}{l}\text { Minimal infestation because most infrastructure near } \\
\text { saltwater. }\end{array}$ & \\
\hline Rock Island & MVR & Yes & Widespread & $\begin{array}{l}\text { Much less abundant } \\
\text { now and population } \\
\text { is stabilized }\end{array}$ \\
\hline St. Louis & MVS & Yes (1) & Mississippi River and connected waters (1) & $\begin{array}{l}\text { Invasion started in } \\
1991 \text { (Mississippi } \\
\text { River) (1) }\end{array}$ \\
\hline St. Paul & MVP & Yes & $\begin{array}{l}\text { Gull Lake, Cross Lake Dam, Pine River Dam. Zebra } \\
\text { mussels present in the Mississippi River primarily } \\
\text { downstream of Lake Pepin in Pool 4. Zebra mussels } \\
\text { present at Locks and Dams } 4 \text { - 10. Recently } \\
\text { observed at Lake Ashtabula in North Dakota } \\
\text { (Sheyenne River, 2) }\end{array}$ & $\begin{array}{l}\text { In the Upper } \\
\text { Mississippi River } \\
\text { (UMR), populations } \\
\text { are fluctuating } \\
\text { annually with die off } \\
\text { and recruitment } \\
\text { events at all } \\
\text { structures. }\end{array}$ \\
\hline Vicksburg & MVH & Yes & $\begin{array}{l}\text { No recent activity except at \#3 Lock and Dam on Red } \\
\text { River }\end{array}$ & \\
\hline Baltimore & NAB & Yes & $\begin{array}{l}\text { Cowanesque Lake and Curwensville Lake, low } \\
\text { density and abundance. }\end{array}$ & $\begin{array}{l}\text { Population on } \\
\text { decline over last few } \\
\text { years }\end{array}$ \\
\hline New England & NAE & Yes & Minimal infestation & \\
\hline New York & NAN & Yes (2) & Non-typical USACE infrastructure & $\begin{array}{l}\text { Invaded Lake } \\
\text { Champlain in } 1993 \\
\text { (3) }\end{array}$ \\
\hline Norfolk & NAO & No (3) & Non-typical USACE infrastructure & $\begin{array}{l}\text { Observed in } \\
\text { Potomac River } \\
\text { Basin in nearby } \\
\text { Baltimore District(4) }\end{array}$ \\
\hline Philadelphia & NAP & Yes & Blue Marsh Lake & \\
\hline Kansas City & NWK & Yes & $\begin{array}{l}\text { Widespread. Just recently found on the downstream } \\
\text { side of Harry S. Truman Dam }\end{array}$ & $\begin{array}{l}\text { Relatively recent } \\
\text { infestations }\end{array}$ \\
\hline Omaha & NWO & Yes & $\begin{array}{l}\text { Yes, at Gavins Point Dam. Not yet at Fort Randall } \\
\text { Dam in 2018, but expecting them soon there in raw } \\
\text { water piping. Literature shows present in Missouri } \\
\text { River and lakes near Omaha, NE, and Lewis and } \\
\text { Clark Lake on NE/SD border (5,6). More recently } \\
\text { discovered in Lake Sharpe, which is past Fort Randall } \\
\text { Dam (7). }\end{array}$ & \\
\hline Portland & NWP & No & Not present & \\
\hline
\end{tabular}




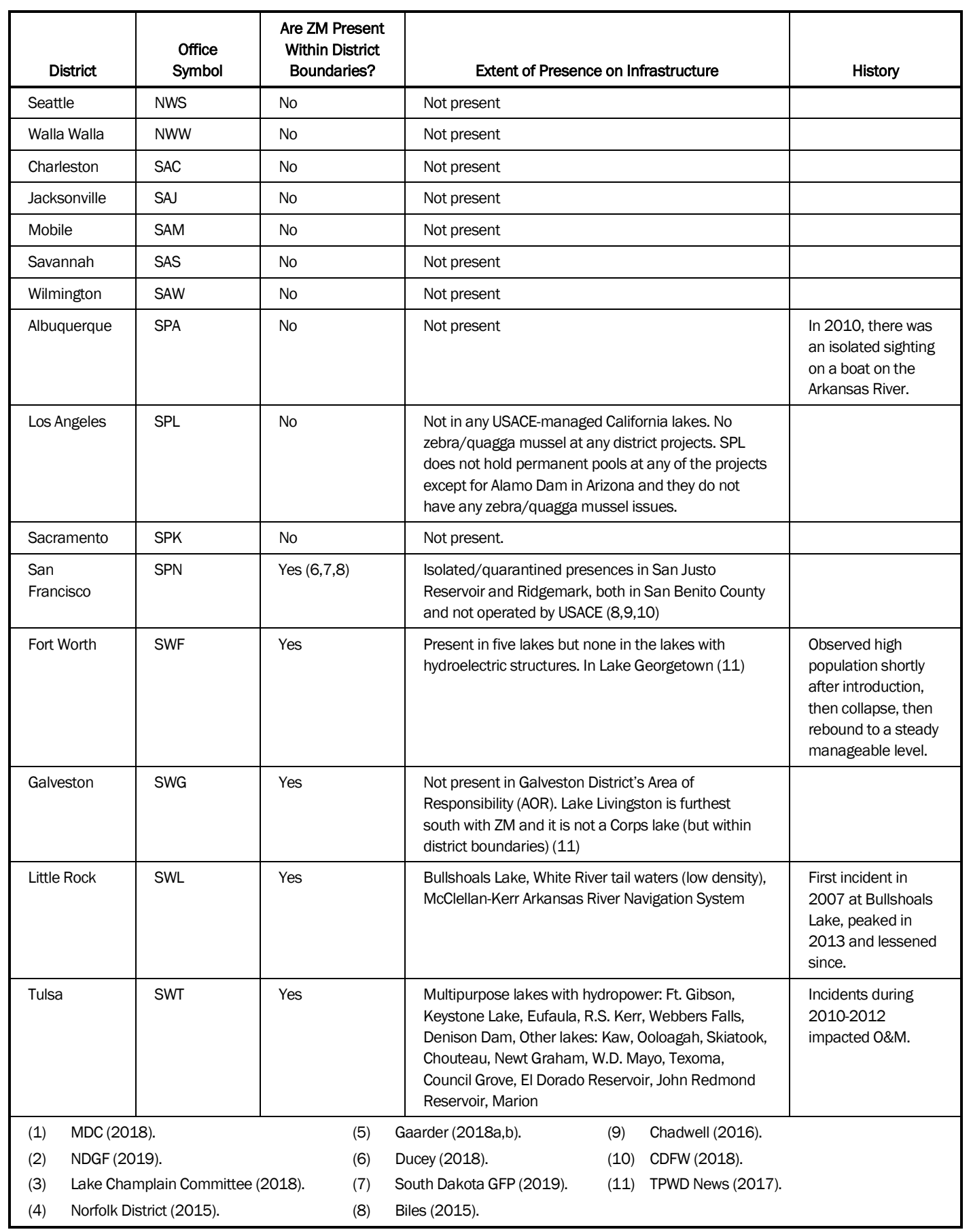

\subsubsection{Impacts of Mussels on Corps Infrastructure}

Table 2 lists summarized and edited responses from the districts regarding questions related to the impact zebra mussels have or have had on their infrastructure. This table only includes the districts that provided answers to these questions. 
Table 2. Summarized district response regarding impacts of zebra mussels.

\begin{tabular}{|c|c|c|c|c|c|}
\hline District & $\begin{array}{l}\text { Office } \\
\text { Symbol }\end{array}$ & Surfaces & O\&M Impact & Mitigation & Prevention \\
\hline Buffalo & LRB & & $\begin{array}{l}\text { No interference with } \\
\text { operations and don't } \\
\text { typically add O\&M costs, } \\
\text { minor nuisance }\end{array}$ & & \\
\hline Chicago & LRC & $\begin{array}{l}\text { Found on steel } \\
\text { and concrete, but } \\
\text { not the rubber } \\
\text { seals. Also possibly } \\
\text { around the } \\
\text { Metropolitan } \\
\text { Water } \\
\text { Reclamation } \\
\text { District (MWRD) } \\
\text { controlled } \\
\text { structures near } \\
\text { lock (sluice gates). } \\
\text { A lot on flooring } \\
\text { mooring bits and } \\
\text { bottom of gates. } \\
\text { Probably in valve } \\
\text { tunnels. }\end{array}$ & $\begin{array}{l}\text { No increased maintenance } \\
\text { specifically due to mussel } \\
\text { attachment, yet. }\end{array}$ & $\begin{array}{l}\text { Any attachment } \\
\text { near submerged } \\
\text { moving parts seem } \\
\text { to be crushed or } \\
\text { swept off during } \\
\text { operation. }\end{array}$ & \\
\hline Detroit & LRE & $\begin{array}{l}\text { Typically observed } \\
\text { adhered to armor } \\
\text { stone, steel sheet } \\
\text { pile and timber } \\
\text { cribbing on } \\
\text { navigation } \\
\text { structures (piers, } \\
\text { breakwaters, } \\
\text { revetments) }\end{array}$ & $\begin{array}{l}\text { Do not interfere with our } \\
\text { routine O\&M as there is } \\
\text { minimal O\&M associated } \\
\text { with these structures }\end{array}$ & None & No \\
\hline Huntington & LRH & $\begin{array}{l}\text { Adhered to gates, } \\
\text { sills, cables, } \\
\text { tunnels, boats, } \\
\text { docks, etc. }\end{array}$ & $\begin{array}{l}\text { Infestations at Dewey Lake } \\
\text { resulted in extra cleaning } \\
\text { and maintenance of gate } \\
\text { structures. There was no } \\
\text { down time for our flood } \\
\text { control structures. }\end{array}$ & $\begin{array}{l}\text { Regular exercising } \\
\text { of outlet gates }\end{array}$ & No \\
\hline Louisville & LRL & $\begin{array}{l}\text { Lock and dam } \\
\text { surfaces, gaging } \\
\text { stations and raw } \\
\text { water wells }\end{array}$ & $\begin{array}{l}\text { Not a significant impact on } \\
\text { stations operations so far } \\
\text { (except for interfering with } \\
\text { water quality sensors). }\end{array}$ & $\begin{array}{l}\text { Scraping or } \\
\text { brushing off, } \\
\text { chlorine tablets }\end{array}$ & \\
\hline Nashville & LRN & & $\begin{array}{l}\text { No known current or } \\
\text { potential impacts to } \\
\text { hydropower projects }\end{array}$ & $\begin{array}{l}\text { Chlorination } \\
\text { strategies as a } \\
\text { control technology } \\
\text { were abandoned } \\
\text { sometime after } \\
2002 \text { due to lack of } \\
\text { zebra mussel } \\
\text { fouling problems. }\end{array}$ & $\begin{array}{l}\text { Hydropower plants } \\
\text { at Barkley and } \\
\text { Cheatham Dams } \\
\text { have discontinued } \\
\text { regular monitoring } \\
\text { although the } \\
\text { infrastructure is in } \\
\text { place to conduct } \\
\text { future monitoring, } \\
\text { if deemed } \\
\text { necessary }\end{array}$ \\
\hline Pittsburgh & LRP & $\begin{array}{l}\text { Lock walls, floating } \\
\text { mooring bitts, } \\
\text { intakes, aluminum } \\
\text { bulkheads }\end{array}$ & $\begin{array}{l}\text { No reports of impact to } \\
\text { steel structures, significant } \\
\text { corrosion to aluminum } \\
\text { maintenance bulkheads } \\
\text { (decreased lifetime) }\end{array}$ & $\begin{array}{l}\text { Coatings on } \\
\text { aluminum } \\
\text { bulkheads to } \\
\text { minimize corrosion }\end{array}$ & \\
\hline Memphis & MVM & $\begin{array}{l}\text { Concrete, attached } \\
\text { to Articulated } \\
\text { Concrete Mat } \\
\text { (ACM) }\end{array}$ & & & Monitoring \\
\hline New Orleans & MVN & & Not lately & & \\
\hline Rock Island & MVR & Concrete & $\begin{array}{l}\text { There is no known direct } \\
\text { impact but it could be a tax }\end{array}$ & & $\begin{array}{l}\text { Adult zebra mussel } \\
\text { populations are }\end{array}$ \\
\hline
\end{tabular}




\begin{tabular}{|c|c|c|c|c|c|}
\hline District & $\begin{array}{l}\text { Office } \\
\text { Symbol }\end{array}$ & Surfaces & O\&M Impact & Mitigation & Prevention \\
\hline & & & $\begin{array}{l}\text { on the system such as } \\
\text { eroding the concrete faster } \\
\text { needing replacement or } \\
\text { repair more quickly }\end{array}$ & & $\begin{array}{l}\text { monitored along } \\
\text { with long-term } \\
\text { native mussel } \\
\text { populations in all } \\
\text { pools } 11 \text {-16 of the } \\
\text { UMR. Veliger } \\
\text { monitoring is } \\
\text { ongoing at } \\
\text { Cordova, IL in Pool } \\
14 \text {. }\end{array}$ \\
\hline St. Paul & MVP & $\begin{array}{l}\text { Gate's skin plate } \\
\text { and concrete piers }\end{array}$ & $\begin{array}{l}\text { Just had a recent incident at } \\
\text { Gull Lake, MN - opened a } \\
\text { gate on a dam and couldn't } \\
\text { close it due to ZM. }\end{array}$ & $\begin{array}{l}\text { Empty zebra } \\
\text { mussel shells } \\
\text { impacted barge } \\
\text { passage with locks } \\
\text { and dams in the } \\
\text { late 1990s. } \\
\text { Dredged from lock } \\
\text { chambers and } \\
\text { deposited in } \\
\text { approved landfills. }\end{array}$ & $\begin{array}{l}\text { Adult zebra mussel } \\
\text { populations are } \\
\text { monitored along } \\
\text { with long-term } \\
\text { native mussel } \\
\text { populations in all } \\
\text { pools of the UMR. } \\
\text { Veliger monitoring } \\
\text { also occurred until } \\
2012 \text { in the UMR } \\
\text { and major } \\
\text { tributaries and } \\
\text { continues in the St. } \\
\text { Croix River } \\
\text { watershed. }\end{array}$ \\
\hline Vicksburg & $\mathrm{MVH}$ & Concrete walls & $\begin{array}{l}\text { No recent activity except \#3 } \\
\text { lock and dam on Red River }\end{array}$ & & \\
\hline Baltimore & NAB & $\begin{array}{l}\text { Along the shoreline } \\
\text { and on concrete } \\
\text { trash racks, } \\
\text { underside of } \\
\text { beach and } \\
\text { navigational } \\
\text { buoys, concrete } \\
\text { walls inside of wet } \\
\text { wells }\end{array}$ & None & None & $\begin{array}{l}\text { Projects display } \\
\text { informational signs } \\
\text { to deter boaters } \\
\text { from transporting } \\
\text { zebra mussels and } \\
\text { other invasive } \\
\text { species into and } \\
\text { out of lakes. } \\
\text { Monitoring done } \\
\text { during routine } \\
\text { inspections. }\end{array}$ \\
\hline New England & NAE & $\begin{array}{l}\text { Concrete, steel, } \\
\text { aluminum, } \\
\text { submerged } \\
\text { structures and } \\
\text { equipment, } \\
\text { navigation gate } \\
\text { safety railings, top } \\
\text { gate access } \\
\text { hatches, two } \\
\text { navigation gate } \\
\text { lifting arms, gate } \\
\text { sill and gate } \\
\text { pedestals on the } \\
\text { bottom of the } \\
\text { channel. }\end{array}$ & $\begin{array}{l}\text { Yes, it is a recurring } \\
\text { maintenance item about } \\
\text { three times per year. Also, } \\
\text { they minimally effect } \\
\text { corrosion and the } \\
\text { functionality of water level } \\
\text { sensors. }\end{array}$ & $\begin{array}{l}\text { Removed by } \\
\text { scraping. Also tried } \\
\text { pressure washing, } \\
\text { but it was not very } \\
\text { effective. }\end{array}$ & \\
\hline Philadelphia & NAP & & & & $\begin{array}{l}\text { Blue Marsh Lake } \\
\text { has a monitoring } \\
\text { program }\end{array}$ \\
\hline Omaha & NWO & & $\begin{array}{l}\text { Zebra Mussels within the } \\
\text { Gavins Point Project have } \\
\text { resulted in upwards of a } \\
50 \% \text { increase in the time } \\
\text { needed to complete routine } \\
\text { maintenance tasks that } \\
\text { involve the plants cooling } \\
\text { water systems. Omaha can } \\
\text { only qualify but not quantify } \\
\text { the impacts }\end{array}$ & $\begin{array}{l}\text { Current plan is to } \\
\text { use an ultrasonic } \\
\text { device to kill the } \\
\text { mussels as/if they } \\
\text { enter our raw water } \\
\text { piping. }\end{array}$ & \\
\hline
\end{tabular}




\begin{tabular}{|c|c|c|c|c|c|}
\hline District & $\begin{array}{l}\text { Office } \\
\text { Symbol }\end{array}$ & Surfaces & O\&M Impact & Mitigation & Prevention \\
\hline Albuquerque & SPA & & & & $\begin{array}{l}\text { Yes (funding is an } \\
\text { issue). Early } \\
\text { detection program } \\
\text { with water } \\
\text { sampling and } \\
\text { analysis. Monitor } 6 \\
\text { projects by } \\
\text { sampling plankton } \\
\text { between June and } \\
\text { September. Also } \\
\text { some boat } \\
\text { inspections are } \\
\text { done by NM and } \\
\text { CO State Parks. }\end{array}$ \\
\hline Sacramento & SPK & & & & $\begin{array}{l}\text { Monthly substrate } \\
\text { monitoring, posted } \\
\text { bulletins, } \\
\text { partnership with } \\
\text { the California } \\
\text { Department of Fish } \\
\text { and Wildlife } \\
\text { (CDFW) }\end{array}$ \\
\hline Fort Worth & SWF & $\begin{array}{l}\text { Gates, concrete } \\
\text { surfaces. }\end{array}$ & & $\begin{array}{l}\text { They have scraped } \\
\text { off in past but put } \\
\text { coatings on } 4 \text { to } 5 \\
\text { years ago and are } \\
\text { now considering } \\
\text { new coatings to } \\
\text { redo. }\end{array}$ & $\begin{array}{l}\text { Early detection } \\
\text { program with the } \\
\text { state, academia } \\
\text { and USGS. Careful } \\
\text { water } \\
\text { management } \\
\text { practices }\end{array}$ \\
\hline Little Rock & SWL & $\begin{array}{l}\text { Found on all } \\
\text { surfaces below } \\
\text { water surface } \\
\text { down to around } 35 \\
\text { feet on the lake } \\
\text { side of Bull Shoals } \\
\text { Dam. Most } \\
\text { concerning are the } \\
\text { ones adhering to } \\
\text { intake openings } \\
\text { and pipes which } \\
\text { could in time } \\
\text { cause water inflow } \\
\text { restrictions and } \\
\text { even blockage. }\end{array}$ & None & $\begin{array}{l}\text { None, other than } \\
\text { scraping them off of } \\
\text { areas above the } \\
\text { normal water line } \\
\text { left behind after a } \\
\text { high water event. }\end{array}$ & No \\
\hline Tulsa & SWT & & $\begin{array}{l}\text { O\&M impacts to each } \\
\text { hydropower facility varies } \\
\text { and dependent on stage of } \\
\text { invasion, type of strainers, } \\
\text { and design of powerhouse. } \\
\text { The design of three } \\
\text { powerhouses (Eufaula, R.S. } \\
\text { Kerr, and Denison) includes } \\
\text { a deluge system for the } \\
\text { facility's transformer fire } \\
\text { suppression, which can be } \\
\text { impacted by zebra mussels. } \\
\text { In 2012, Ft. Gibson reported } \\
\text { an increase in O\&M by } 10 \\
\text { work hours due to impacts } \\
\text { on A/C system. At Eufaula in } \\
2010 \text {, it took } 10 \text { work hours } \\
\text { (\$905.00) to clean clogged } \\
\text { cooling water intake } \\
\text { strainers and } 48 \text { work hours } \\
(\$ 4,344.00) \text { to clean the } \\
\text { main unit head gates. In } \\
2011, \text { it took } 10.5 \text { work }\end{array}$ & $\begin{array}{l}\text { Chlorine } \\
\text { tablets/injectors } \\
\text { have not been used }\end{array}$ & \\
\hline
\end{tabular}




\begin{tabular}{|c|c|c|c|c|c|}
\hline District & $\begin{array}{l}\text { Office } \\
\text { Symbol }\end{array}$ & Surfaces & O\&M Impact & Mitigation & Prevention \\
\hline & & & $\begin{array}{l}\text { hours ( } \$ 950.00 \text { ) to clean } \\
\text { cooling water intake } \\
\text { strainers and } 4 \text { work hours } \\
\text { ( } \$ 362.00 \text { ) to clean } \\
\text { transformer fire suppression } \\
\text { equipment. In } 2012,7 \text { work } \\
\text { hours }(\$ 724.00 \text { ) were spent } \\
\text { cleaning cooling water } \\
\text { intake strainers and } 8 \text { work } \\
\text { hours were spent on } \\
\text { cleaning transformer fire } \\
\text { suppression equipment. } \\
\text { During fire suppression tests } \\
\text { (2012), impacted function } \\
\text { of the system by clogging } \\
\text { the pump and the process } \\
\text { was stopped, pump } \\
\text { filter/strainer cleaned, and } \\
\text { process restarted. This } \\
\text { interruption occurred } \\
\text { several times and had there } \\
\text { been an actual need for the } \\
\text { fire suppression, there may } \\
\text { have been complications. }\end{array}$ & & \\
\hline
\end{tabular}




\section{Discussion}

\subsection{Mussel occurrence on Corps infrastructure}

The results of the questionnaire and literature search indicated that zebra mussels are present in 24 CONUS USACE districts. This includes all the districts in the Great Lakes and Ohio River and Mississippi Divisions, all in the North Atlantic Division except Norfolk (Norfolk District 2015), all in the Southwestern Division, the Kansas City and Omaha districts in the Northwestern Division, and the San Francisco District in the South Pacific Division. These results are mostly consistent with the reported sightings in the USGS database (USGS 2019) as shown in Figures 9 and 8, except for some isolated sightings out in the western portion of CONUS (Colorado, Utah, and Montana) and Alabama. These discrepancies are mostly due to isolated one time incidents in which zebra mussels are no longer present or the status of mussel persistence is unknown. The occurrences in Colorado and Utah (all 2008) are each based on a single report and have either a "failed" or "extirpated" status. Montana's occurrence is due to a single observation in 2016 with a current "unknown" status. In Alabama (Mobile District), zebra mussels have been reported nearby in the Tennessee River according to the USGS database, but literature evidence of their presence within the district boundaries is elusive. The USGS database has two recent (2017) individual observations within the district boundaries near Bankhead Lake, but both currently with "unknown" status. This could be an indication that Mobile District may be at risk for invasion. Albuquerque and Omaha (already experiencing a presence, Ducey 2018) also seem to be at risk based on the questionnaire responses.

The results of mussel presence indicated in Table 1 and Figure 8 are based on the district boundaries and not on whether mussels are present in USACE-managed waters. San Francisco District, for example, has two patches shown in Figure 9 that are due to two isolated observations in 2008 and 2012 and currently listed with "established" status by USGS. The 2008 observation is at San Justo Reservoir (not a USACE lake), which has been under quarantine since 2008 and an eradication plan has been pursued (O’Meara and Hosler 2016). 
Figure 8. USACE districts with a zebra mussel presence within district boundaries, shading represents a presence.

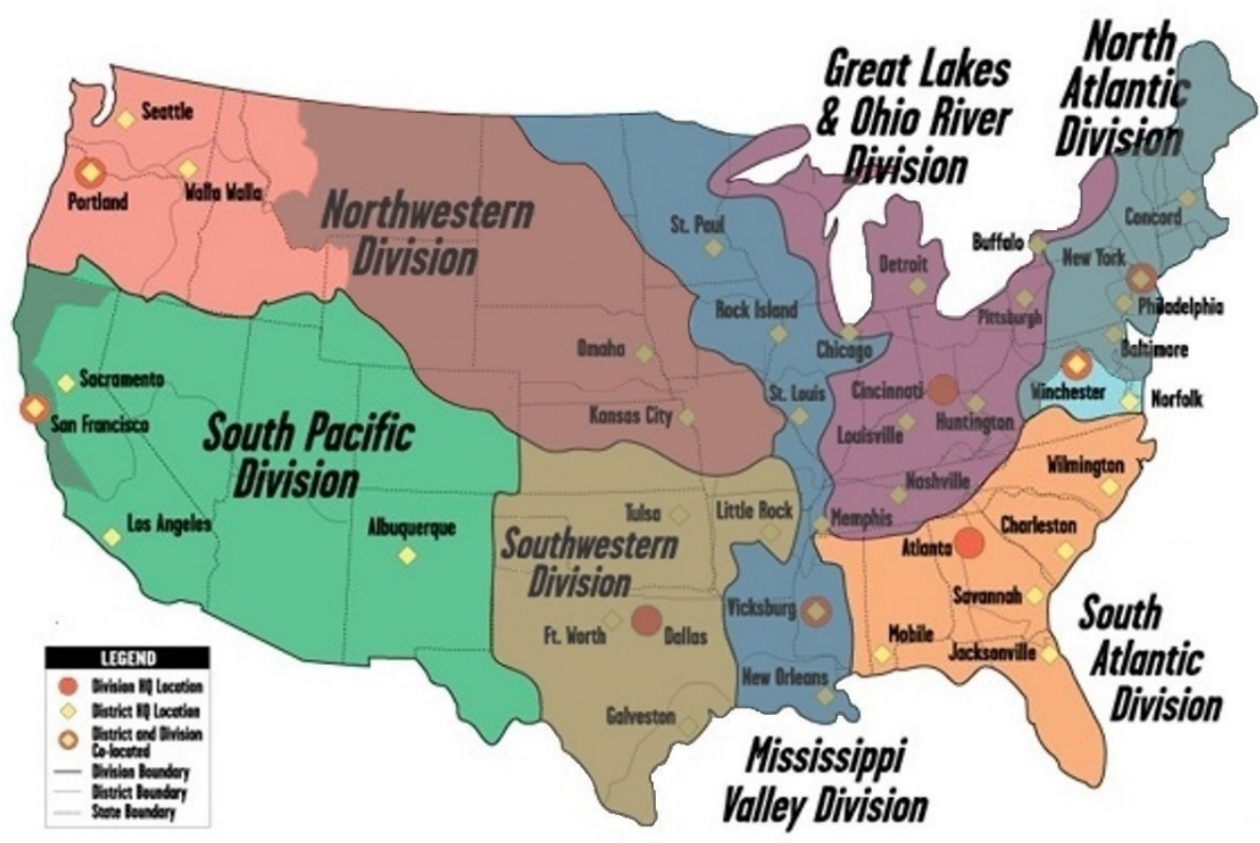

Source: $\underline{\text { https://www.usace.army.mil/Locations/. }}$

Figure 9. USGS database representation of zebra mussel observations.

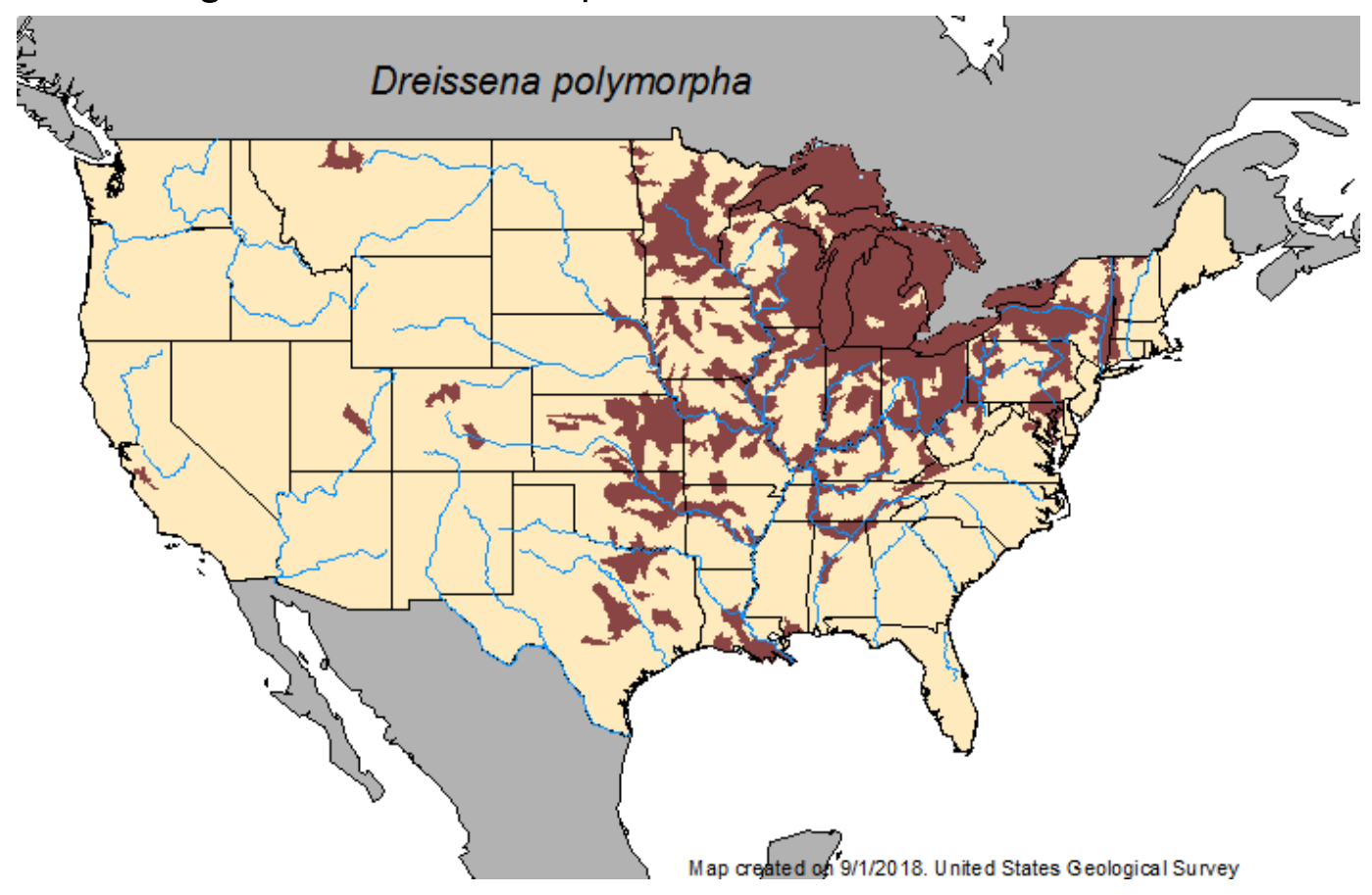


The 2012 sighting is at a nearby golf course, the Ridgemark gold course pump (CDFW 2018). Neither site is currently a threat to San Francisco District. Galveston District is another example. The only observed and currently active mussel presence is in Lake Livingston (TPWD News 2017), which is within the district boundaries but not a USACE-managed lake.

The general history of the zebra mussel infestation is that it first occurred in the Great Lakes (most likely Lake Erie) and spread across the country via waterways and boats. The infestation started during the late 1980 s in the Great Lakes and Ohio River Division, and spread to the North Atlantic Division and the Mississippi Valley Division in the early 1990s, and then infested the Southwestern Division by the 2000s (Benson 2014). In many districts, that have been infested for multiple years, the zebra mussel population stabilized after experiencing a boom followed by a die off. This pattern was supported by responses from seven districts (Huntington, Nashville, Pittsburgh, Rock Island, Baltimore, Fort Worth, and Little Rock). The districts that are experiencing noticeable infestations are near the outer edges of the infestation pattern, where new populations are in the beginning stages of establishment, shown by Figures 8 and 9. These include Kansas City, St. Paul, New England, Vicksburg and perhaps, Fort Worth and Tulsa. Omaha is also just inside the expanding boundaries of mussels and is currently experiencing an invasion. Those districts just outside the establishment boundaries (Albuquerque, Mobile) may be at risk of invasion. It is also interesting to observe that the zebra mussels have almost completely avoided the South Atlantic Division, perhaps due to environmental factors. The lack of establishment in the South Atlantic Divisions may indicate that if Mobile District is eventually invaded, the infestation may not be as severe as the infestations that occurred in northern and western Districts.

Most of the districts that report zebra mussels in USACE-managed waters also report that they are present on USACE infrastructure. One notable exception to this is Fort Worth, where they are present in five lakes but not in the lakes with hydroelectric structures.

\subsection{Extent of mussel impacts at Corps Infrastructure}

According to the questionnaire responses, zebra mussels were found to adhere to most underwater surface, including concrete, metal, wood, and aluminum. This is consistent with the widely known behavior of zebra mussels (Snyder et al. 1992, Marsden and Lansky 2000). The only notable exception was with the Chicago District reporting that the zebra mussels 
did not attach to rubber which can be found on seals for some movable components, such as gates. This is in contrast to Snyder et al. (1992), who specifically mention rubber and vinyl as suitable substrates, and to Miller and Payne (1992), who specifically discuss rubber gate seals as being vulnerable to zebra mussel attachment.

Miller and Payne (1992) also present the different types of public infrastructure that are potentially vulnerable to zebra mussels (Table 3).

Table 3. Facilities/structures likely to be affected by zebra mussels (Miller and Payne 1992).

\begin{tabular}{|c|c|}
\hline Facility & Structure \\
\hline Navigation (Gated) Locks & Reservoirs and Outlet Works \\
\hline Chamber walls & Spillways (crest, gates, and energy dissipaters) \\
\hline Water intakes & $\begin{array}{l}\text { Conduits (intakes, screens, emergency and regulating valves, } \\
\text { and energy dissipaters) }\end{array}$ \\
\hline Filling and emptying valves & Emergency closures and dewatering valves \\
\hline Culvert walls & Water quality release works (valves and monitoring equipment) \\
\hline $\begin{array}{l}\text { Lower and upper approaches (including } \\
\text { navigation buoys) }\end{array}$ & $\begin{array}{l}\text { Associated recreation areas (docks, boat ramps, floating } \\
\text { structures, beaches, and swimming areas) }\end{array}$ \\
\hline \multicolumn{2}{|l|}{ Upper gates } \\
\hline Lower gates & Pumping Plants \\
\hline Emergency closure & Approach (trash racks, approach walls, and chamber) \\
\hline Navigation aids & Pump (propellers, propeller shafts, and suction bell) \\
\hline Dewatering equipment (including bulkhead slots) & Delivery line \\
\hline Monitoring equipment & Dewatering equipment \\
\hline Mooring bits & Monitoring equipment \\
\hline \multicolumn{2}{|l|}{ Ladders } \\
\hline $\begin{array}{l}\text { Piping (including raw water facilities such as } \\
\text { those used for fire protection) }\end{array}$ & Drainage Structures \\
\hline \multirow[t]{2}{*}{ Grating and screening } & Gaging Stations (staff gates, float gates, and bubble gages) \\
\hline & Flood walls and gates \\
\hline Navigation Dams & Flap gates \\
\hline $\begin{array}{l}\text { Control gates (opening and closing, as well as } \\
\text { seals and crests) }\end{array}$ & Debris control structures \\
\hline Navigation pass (wickets and sills) & Grade control structures \\
\hline Dewatering and emergency closure & $\begin{array}{l}\text { Flow control and water level control structures (stop logs and } \\
\text { rubber dams) }\end{array}$ \\
\hline \multicolumn{2}{|l|}{ Maintenance equipment } \\
\hline \multirow[t]{3}{*}{ Monitoring equipment } & Hydropower \\
\hline & Turbines \\
\hline & Water distribution systems \\
\hline
\end{tabular}


Structures mentioned in the questionnaire results include many of the entries in Table 3, but more specifically they are: gates (all parts except rubber seals), valve tunnels, timber cribbing on navigational structures (piers, breakwaters, revetments), cables, boats, docks, lock and dam surfaces, gaging stations, raw water wells, floating mooring bits, intake openings and pipes, concrete trash racks, underside of beach, navigational buoys, water sensors, transformer fire suppression equipment, and cooling water intake strainer. The questionnaire yielded consistently similar structures (to which zebra mussels have adhered) as described in the list provided by Miller and Payne [1992], with the only inconsistencies being either vaguely included in the structures of Table 3 (e.g., cribbing, cables) or not considered infrastructure, more specifically "boat." However, recreational boat hulls were specifically mentioned as impacted by zebra mussels by Cole et al. (2010) in their report regarding impacts of aquatic nuisance species at USACE projects. In summary, it appears that zebra mussels do not exclude any surfaces or structures to which they can attach, although can do so with varying degrees of preference (Marsden and Lansky 2000) and with the possible exception of rubber seals.

Of the 22 districts that have zebra mussels in USACE-managed waters excluding St. Louis (nonresponse), 13 (62\%) reported no or minimal impacts to infrastructure O\&M. Many of these installations have had mussel long standing mussel infestations and several discussed the history of these infestations. The general sense was that the mussel invasion was strong at first, then died off and has stabilized at manageable levels. Some of these installations have experienced an impact on O\&M in the past but are no longer impacted beyond a perceived minor nuisance. This is particularly true for the Great Lakes and Ohio Division, where the initial invasion began.

The remaining eight districts with zebra mussel occurrences in USACEmanaged waters had notable impacts: Huntington, Pittsburgh, St. Paul, Vicksburg, New England, Omaha, Fort Worth, and Tulsa. Four of these districts are notable because of isolated recent incidents: at Huntington a buildup on Dewey Lock required extra cleaning and maintenance on the gate structures; at St. Paul, a gate could not be closed due to the buildup of zebra mussels; at Vicksburg there has been the infestation at \# 3 Lock and Dam on Red River; and at Omaha it has been reported that maintenance time has increased by about 50\% at Gavins Point Dam. New England District has a recurring maintenance three times per year due to mussels and experience corrosion and water level sensor damage. Fort Worth District 
has had to scrape mussels off their infrastructure in the past and have applied coatings. They are currently needing to recoat some surfaces. Tulsa District experienced numerous O\&M issues back in 2010-2012 that were detailed in Table 2, which resulted in about $\$ 7 \mathrm{~K}$ in extra costs. Pittsburgh District has experienced significant corrosion issues with their temporary aluminum maintenance bulkheads (see Figures 2 and 3). Figures 10 and 11 show zebra mussels concentrated around stainless steel bolts on a Montgomery Locks and Dam aluminum bulkhead. Figures 12 and 13 show the corrosion remaining after the bulkhead was power-washed.

Figure 10. Zebra mussels on Montgomery aluminum bulkhead (image 1).

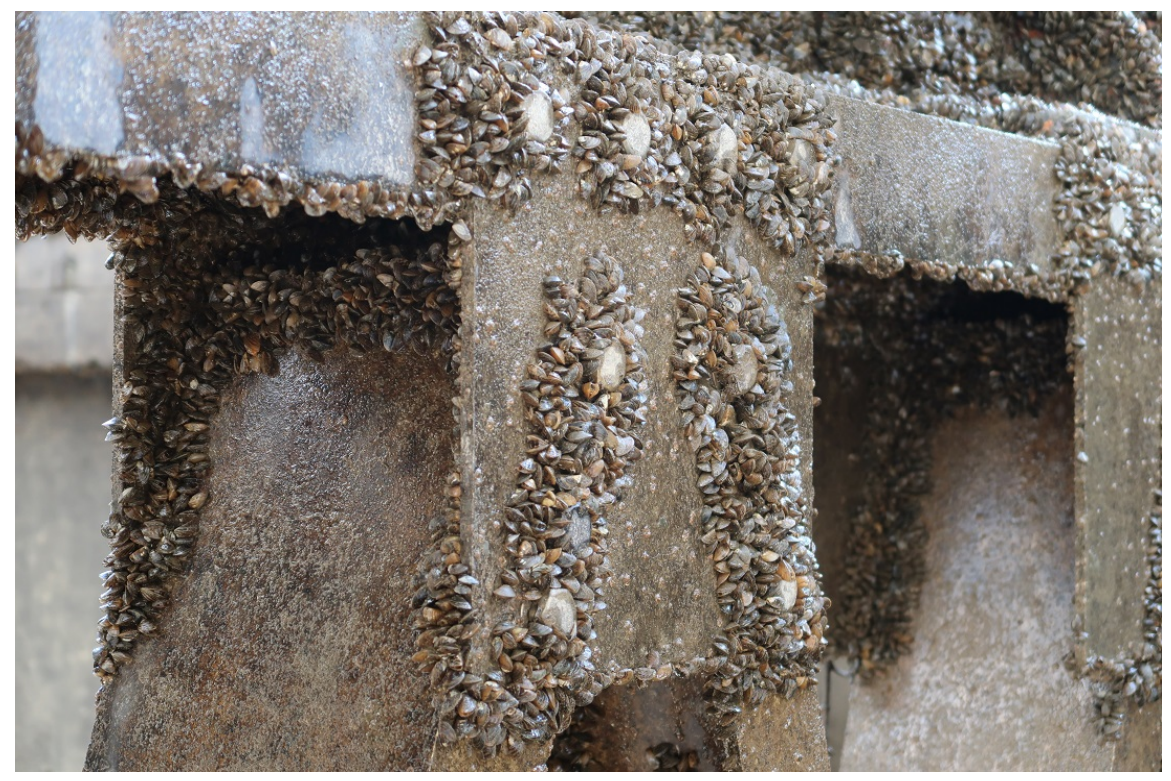

Figure 11. Zebra mussels on Montgomery aluminum bulkhead (image 2).

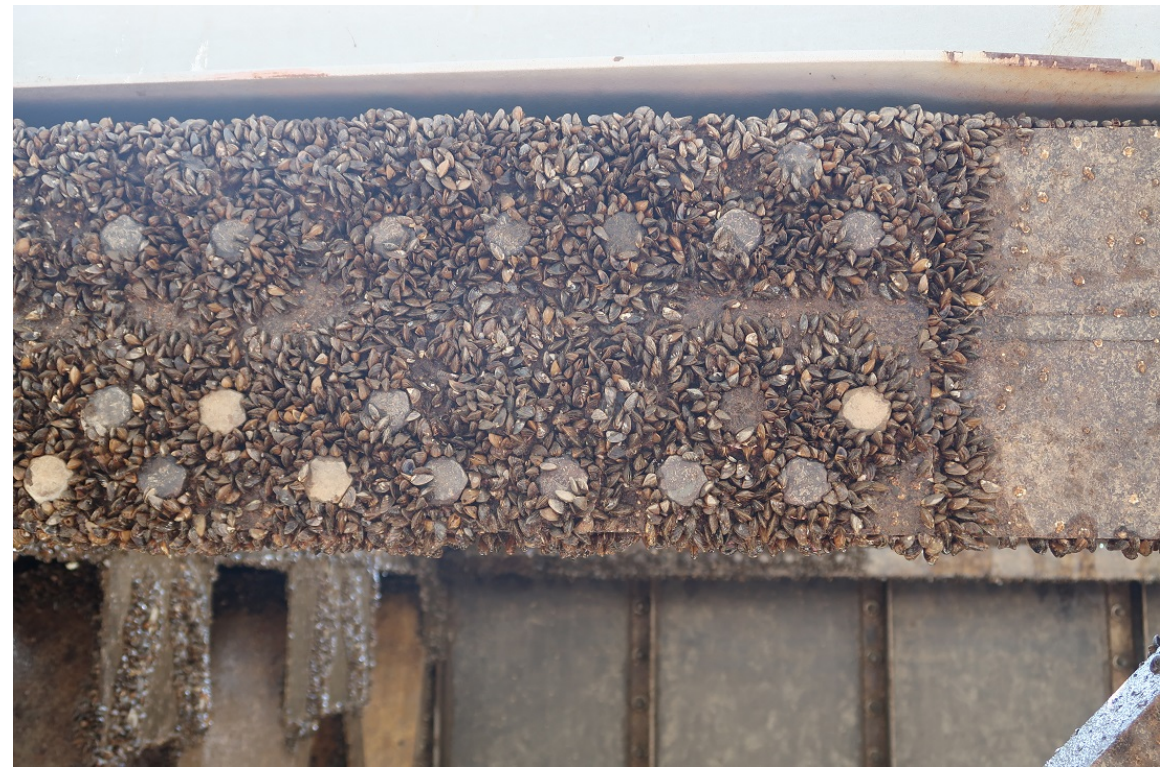


Figure 12. Montgomery aluminum bulkhead after power washing.

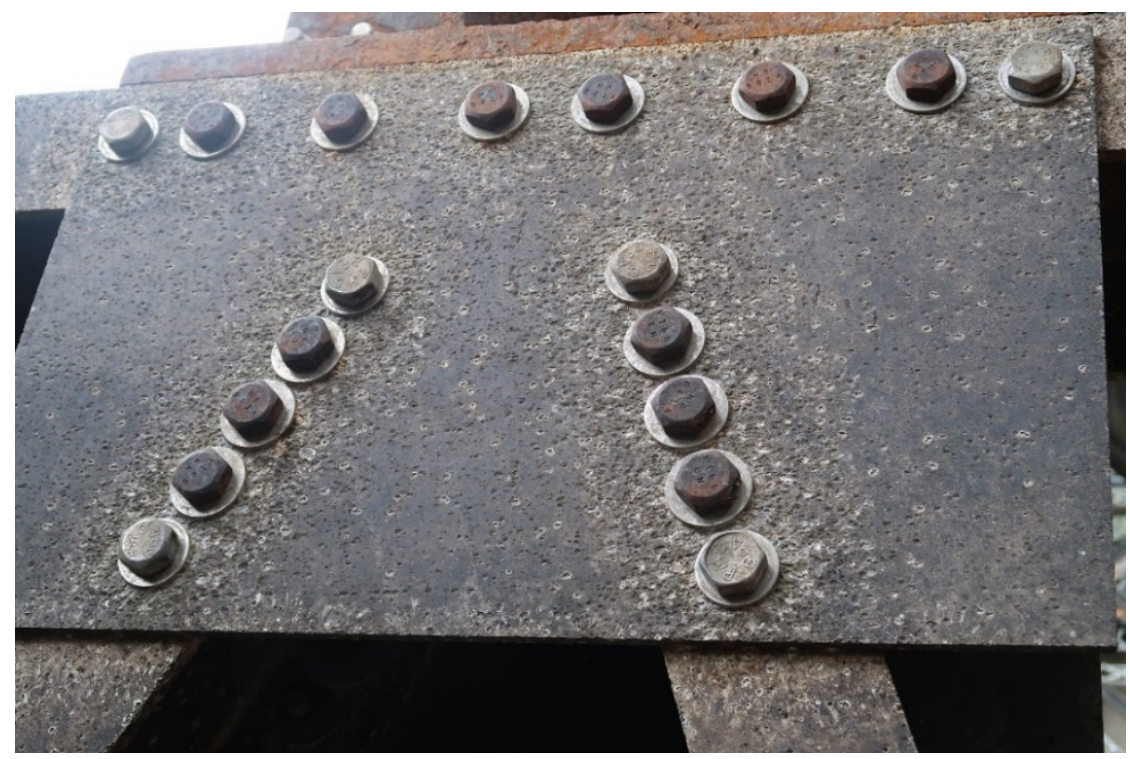

Figure 13. Montgomery aluminum bulkhead after power washing (closeup).

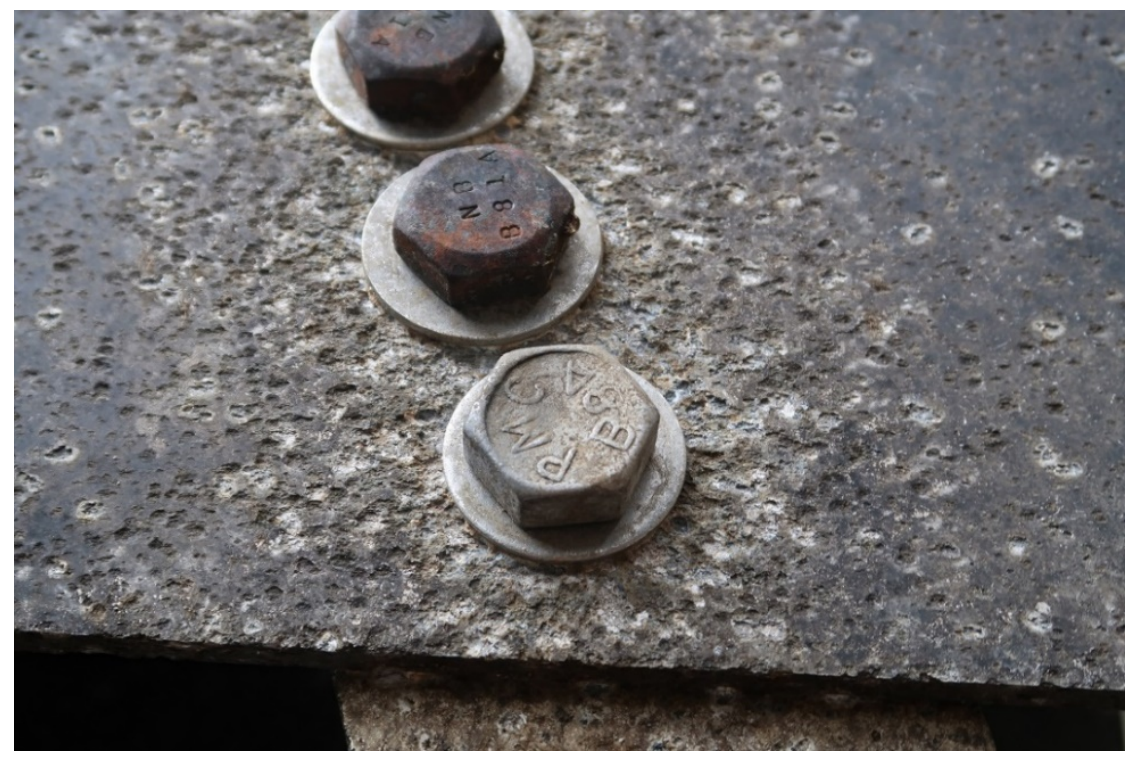

Other than the cost figures provided by Tulsa District, costs are not well known or documented. The ISLT also does not have good cost accounting of the impacts caused by ZM (Appendix C). It is noticeable that the costs and maintenance activities that are reported do not seem exorbitant, and do little to support the estimated costs in CPW (2016). Cole et al. (2010) found that while there have been some exorbitant cost estimates attributed to zebra mussels, their survey did not reveal any management costs directly due to zebra mussels at USACE infrastructure. Cole et al. also point out that none of the locks covered by their survey were impacted even though zebra mussels were present. 
According to the questionnaire responses currently employed mitigation techniques used by USACE include scraping, chlorination, and exercising movable parts to crush and sweep off. Omaha District mentioned that they plan to use an ultrasonic device if zebra mussels invade their raw water piping (at Fort Randall Dam). The U.S. Department of Interior (USDOI 2016, 2017) actually suggest using an ultraviolet treatment for the cooling water system at Fort Randall Dam (not ultrasonic), like the system they installed at Parker Dam (Quinn 2018). USACE planned to drain Cunningham Lake near Omaha, NE (Gaardner 2018b)

In relation to mussel prevention, some districts report having monitoring programs to alert of possible invasions or proliferation. These districts are Memphis, Rock Island, St. Paul, Baltimore, Philadelphia, Albuquerque, Sacramento, and Fort Worth. Rock Island and St. Paul districts periodically monitor zebra mussel populations at significant native mussel beds by dive surveys in close proximity to Mississippi River locks and dams providing long-term spatial and temporal trends in zebra mussel population levels near infrastructure. ${ }^{*}$ Nashville has monitored in the past and has kept the monitoring equipment in place so that it could start up again if necessary. Not noted in the survey results, Seattle, Portland and Walla Walla districts all conduct some monitoring in conjunction with the $100^{\text {th }}$ Meridian Group, states and USGS. ${ }^{\dagger}$ Fort Worth District has used coatings with some positive results and is now reconsidering newer coatings for reapplication. This indicates that monitoring programs are being successfully used by the districts and that there is some interest in new coating technology.

There seems to be a sense of dread in a couple of districts that are in or on the verge of an invasion (Albuquerque, Omaha) probably because the initial impact of an invasion in a new area can be the largest. These districts have hydropower facilities and there is concern that the zebra mussels will cause costly O\&M impacts.

\footnotetext{
* Kelner, D. E., email communication with author regarding report review, 6 June 2019
}

† Walter, D. J., email communication with author regarding report review, 9 May 2019. 


\section{Conclusion}

The following conclusions were made after a review of current literature and the administered questionnaire to the 36 CONUS USACE districts.

1. ZM are present within 24 district boundaries in varying population densities. Observed densities strongly depend on the phase and longevity of the invasion. Two of those districts have isolated infestations that are not in USACE waters.

2. Survey and literature results for the presence of $\mathrm{ZM}$ are consistent with the USGS reporting database with the exception of a few observations in western CONUS and in the Mobile District.

3. The ZM invasion is slowly spreading west with Albuquerque and Omaha districts at risk for future infestations. Both districts have expressed concern about possible infestations. Mobile District may also experience a future infestation, although ZM have thus far avoided infiltrating the South Atlantic Division. It is likely any future invasion will not be as severe as those documented in neighboring northern and western districts likely due to less favorable environmental conditions.

4. The districts with occurrences of ZM present have observed ZM adhering to their infrastructure and attached to all different types of USACE structures as predicted by Miller and Payne (1992).

5. ZM were found to adhere to all types of surfaces, with the possible exception of rubber.

6. Sixty-two percent of the districts with reported ZM presence in USACE waters claim little to no impacts on their infrastructure or O\&M costs. Actual cost figures are not well known even with the installations experiencing impacts. The results do not support the exorbitant cost figures estimated by the literature.

7. Eight districts reported notable ZM impacts to their infrastructure. Those districts are near the outside borders of the invasion map and have had more recent infestations.

8. The common pattern of invasion that has been observed is one of a peak concentration, a die back and then the stabilization of the ZM population at manageable levels.

9. Twelve districts reported either having current ZM monitoring programs or had monitoring programs in place in the past. These monitoring programs are used to detect ZM presence and/or concentrations.

10. Fort Worth district has previously employed mussel resistant coatings and is currently interested in newer coatings. 


\section{Bibliography}

\section{Cited works}

Benson, A. J. 2014. "Chronological History of Zebra and Quagga Mussels (Dreissenidae) in North America, 1988-2010.” Quagga and Zebra Mussels: Biology, Impacts, and Control. $2^{\mathrm{d}}$ ed. Chapter 1. Boca Rotan, FL: CRC Press.

Biles, D. 2015. "7 Years Later, San Justo Reservoir Still in Limbo." Benito Link: San Benito County's News. https://benitolink.com/7-years-later-san-justo-reservoir-still-limbo.

CDFW (California Department of Fish and Wildlife). 2018. Quagga and Zebra Mussel Sightings Distribution in California, 2007-2017. https://nrm.dfg.ca.gov/FileHandler.ashx?DocumentID=140819\&inline.

Chadwell, J. 2016. San Justo Reservoir May Not Open for Years, If Ever, Officials Say. Benito Link: San Benito County's News. https://benitolink.com/san-justo-reservoirmay-not-open-years-if-ever-officials-say.

Cole, R. A., P. F. Scodari, and M. A. Franklin. 2010. Incidence and Management Costs of Freshwater Aquatic Nuisance Species at Projects Operated by the U.S. Army Corps of Engineers. ERDC/EL TR-10-13. https://apps.dtic.mil/dtic/tr/fulltext/u2/a525578.pdf.

CPW (Colorado Parks \& Wildlife). 2016. Invasion Concerns: Zebra \& Quagga Mussels. https://cpw.state.co.us/aboutus/Pages/ISP-Zebra-Quagga.aspx.

Ducey, M. 2018. “Zebra Mussels Are Spreading in Nebraska's Waters - and Boaters Are Key to Stopping Them.” Omaha World Herald. https://www.omaha.com/outdoors/zebra-mussels-are-spreading-in-nebraska-s-waters-andboaters/article_b7b4a9b8-7003-5aec-b59b-5643e6d4e6d7.html.

Gaarder, N. 2018a. "Zebra Mussel, the Feared Invasive Species, Confirmed in Cunningham Lake." Omaha World-Herald. https://www.omaha.com/news/iowa/zebra-mussel-the-feared-invasive-species-confirmed-incunningham-lake/article_f7aaa0e7-4f3a-50f1-ae21-2f9b128f5305.html.

2018b."Draining of Cunningham Lake Begins; Park To Remain Open.” Omaha World-Herald. https://www.omaha.com/news/metro/draining-of-cunningham-lake-beginspark-to-remain-open/article_b9ade84b-1b17-506f-ab47-aff96370a78d.html.

Invasive Mussel Collaborative. 2018. Strategy To Advance Management of Invasive Zebra and Quagga Mussels. Ann Arbor, MI: Invasive Mussel Collaborative. https://invasivemusselcollaborative.net/wp-content/uploads/2018/11/IMC-Strategy-Nov2018-final.pdf.

Lake Champlain Committee. 2020. Invasive Species. https://www.lakechamplaincommittee.org/lcc-at-work/invasive-species-in-lake/.

Marsden, J. E., and D. M. Lansky. 2000. "Substrate Selection by Settling Zebra Mussels, Dreissena Polymorpha, Relative to Material, Texture, Orientation, and Sunlight.” Canadian Journal of Zoology. 78(5):787-793. 
Mayer, D. A. 2008. The Silent Invasion: Finding Solutions to Minimize the Impacts of Invasive Quagga Mussels on Water Rates, Water Infrastructure and the Environment. Hearing to the U.S. House of Representatives Committee on Natural Resources Subcommittee on Water and Power. https://www.usbr.gov/lc/region/programs/quagga/testimony/cornell.pdf.

Miller, A. C., and B. S. Payne. 1992. Control Strategies for Zebra Mussel Infestations at Public Facilities. Technical Report EL-92-25. Vicksburg, MS: U.S. Army Engineer Waterways Experiment Station (USAWES). https://apps.dtic.mil/dtic/tr/fulltext/u2/a525578.pdf.

MDC (Missouri Department of Conservation). 2018. Zebra Mussel Control https://mdc.mo.gov/wildlife/nuisance-problem-species/invasive-species/zebra-mussel-control.

NDGF (North Dakota Game and Fish Department). 2019. Zebra Mussels Discovered in Lake Ashtabula. Bismarck, ND: NDGF. https://gf.nd.gov/news/3162.

O’Meara, S., and D. Hosler. 2016. Interim Report: Zebra Mussel Eradication, Potash Study San Justo Reservoir. Final Report ST-1610-01. Washington, DC: U.S. Department of the Interior, Bureau of Reclamation.

Pimentel, D., R. Zuniga, and D. Morrison. 2005. "Update on the Environmental and Economic Costs Associated with Alien-Invasive Species in the United States." Ecological Economics. 52(3):273-288.

Quinn, E. 2018. Research Finds HOD UV Treatment Reduces Biofouling Issues at Hydropower Facilities. Washington, DC: U.S. Department of Interior, Bureau of Reclamation. https://www.usbr.gov/newsroom/stories/detail.cfm?RecordID=63943.

Snyder, F. L., D. W. Garton, and M. B. Hilgendorf. 1992. Zebra Mussels in the Great Lakes: The Invasion and Its Implications. Columbus, OH: Ohio State University, Ohio Sea Grant College Program.

South Dakota GFP (Game, Fish, and Parks). 2019. GFP News: Zebra Mussels in Lake Sharpe | Super Tag Raffle Offers Unprecedent Opportunity. State of South Dakota. https://gfp.sd.gov/news/detail/1254/.

Tennessee Aquatic Nuisance Species Task Force. 2008. "Tennessee Aquatic Nuisance Species Management Plan.” Nashville, TN: Tennessee Wildlife Resources Agency. https://www.anstaskforce.gov/State\%20Plans/More/Tnplanfinal.pdf.

TPWD News. 2017. Zebra Mussels Spreading at Lakes Georgetown, Livingston. Austin, TX: Texas Parks \& Wildlife. https://tpwd.texas.gov/newsmedia/releases/?req=20171113a.

USACE (U.S. Army Corps of Engineers). 2018. Civil Works. https://www.usace.army.mil/Missions/Civil-Works/.

2017. Navigation: Economic Impact. https://www.iwr.usace.army.mil/Missions/Value-tothe-Nation/Navigation/Navigation-Economic-Impact/. 
2013. Zebra Mussel Resource Document: Trinity River Basin, Texas. Fort Worth, TX: USACE Fort Worth District.

https://www.swf.usace.army.mil/Portals/47/docs/Environmental/Water/Zebra_Mussel_Resour ce_Document_FINAL.pdf.

USDOI (U.S. Department of Interior). 2018. "San Justo Reservoir Zebra Mussel Eradication." Reclamation: Managing Water in the West. Final Report ST-2018A431-01. Washington, DC: USDOI, Bureau of Reclamation.

_. 2017. "Facility Assessment for Fort Randall Dam \& Powerplant." Reclamation: Managing Water in the West. Washington, DC: USDOI, Bureau of Reclamation.

2016. "Mussel-Related Impacts and Costs at Hoover, Davis, and Parker Dams (Lower Colorado Dams Office Facilities)." Reclamation: Managing Water in the West. Final Report ST-2016-1608. Washington, DC: USDOI, Bureau of Reclamation.

USGS (U.S. Geological Survey). 2019. NAS - Nonindigenous Aquatic Species. https://nas.er.usgs.gov/queries/FactSheet.aspx?speciesID=5.

\section{Uncited works}

U.S. Army Corps of Engineers Waterways Experiment Station. 1998. Corrosion Rates of Ferrous Metals Associated with Zebra Mussel Infestation. Zebra Mussel Research Technical Note ZMR-2-07. Vicksburg, MS: U.S. Army Engineer Waterways Experiment Station (USAWES).

- 1994. Buffalo District Floating Plant Experience with Zebra Mussels. Zebra Mussel Research Technical Note ZMR-3-17. Vicksburg, MS: USAWES.

1992. Zebra Mussels: Biology, Ecology, and Recommended Control Strategies. Zebra Mussel Research Technical Note ZMR-1-01. Vicksburg, MS: USAWES. 


\section{Acronyms and Abbreviations}

\begin{tabular}{|l|l|}
\hline Term & Definition \\
\hline ACM & Articulated Concrete Mat \\
\hline AOR & Area of Responsibility \\
\hline CDFW & California Department of Fish and Wildlife \\
\hline CONUS & Continental United States \\
\hline CPW & Colorado Parks and Wildlife \\
\hline HS & Hydraulic Structure \\
\hline HQUSACE & Headquarters, U.S. Army Corps of Engineers \\
\hline ISLT & Invasive Species Leadership Team \\
\hline MWRD & Metropolitan Water Reclamation District \\
\hline NISC & National Invasive Species Council \\
\hline O\&M & Operations and Maintenance \\
\hline PDT & Project Development Team \\
\hline POC & Point of Contact \\
\hline TPWD & Texas Parks and Wildlife Department \\
\hline UMR & Upper Mississippi River \\
\hline USACE & United States Army Corps of Engineers \\
\hline USGS & United States Geological Survey \\
\hline WWW & World Wide Web \\
\hline ZM & Zebra Mussels \\
\hline
\end{tabular}




\section{Appendix A: Questionnaire Responses}

\section{A.1 Great Lakes and Ohio River Division.}

Table A-1. Questionnaire Responses: Buffalo LRB District.

\begin{tabular}{|l|l|}
\hline Questions & Answers \\
\hline $\begin{array}{l}\text { Are there zebra mussels in your } \\
\text { district? If so, at which locations } \\
\text { within the district are they } \\
\text { present? }\end{array}$ & $\begin{array}{l}\text { The Buffalo District has zebra and quagga mussels } \\
\text { on our lock (Black Rock Lock) at the District Office }\end{array}$ \\
\hline $\begin{array}{l}\text { If not, has the district ever had } \\
\text { zebra mussels (in the past but } \\
\text { died off -may hint at cyclical } \\
\text { patterns)? }\end{array}$ & \\
\hline $\begin{array}{l}\text { How bad is the infestation? } \\
\text { in the district. }\end{array}$ & $\begin{array}{l}\text { Black Rock Lock is the only infrastructure we } \\
\text { operate and maintain besides harbor O\&M. At the } \\
\text { lock, they are at manageable levels. The mussels } \\
\text { are very widespread in the Great Lakes though }\end{array}$ \\
\hline $\begin{array}{l}\text { On what surfaces do they adhere? } \\
\text { Are they on the infrastructure, if } \\
\text { so where? }\end{array}$ & \\
\hline $\begin{array}{l}\text { Are zebra mussels interfering with } \\
\text { O\&M? If so, at what cost? }\end{array}$ & $\begin{array}{l}\text { They don't interfere with operations and don't } \\
\text { typically add O\&M costs, they are a minor nuisance }\end{array}$ \\
\hline $\begin{array}{l}\text { What methods are used for } \\
\text { mussel mitigation (facility retrofit, } \\
\text { scraping, chemicals, jet washing, } \\
\text { desiccation)? }\end{array}$ & \\
\hline $\begin{array}{l}\text { What is an estimate of down time } \\
\text { due to zebra mussel mitigation? }\end{array}$ & \\
\hline $\begin{array}{l}\text { Does your district take any } \\
\text { preventative measures to deter } \\
\text { zebra mussels? }\end{array}$ & \\
\hline $\begin{array}{l}\text { Please provide projects impacted } \\
\text { by zebra mussels and a point of } \\
\text { contact }\end{array}$ & \\
\hline $\begin{array}{l}\text { Additional comments: } \\
\text { maintenance }\end{array}$ \\
\hline
\end{tabular}


Table A-2. Questionnaire Responses: Chicago LRC District.

\begin{tabular}{|c|c|}
\hline Questions & Answers \\
\hline $\begin{array}{l}\text { Are there zebra mussels } \\
\text { in your district? If so, at } \\
\text { which locations within } \\
\text { the district are they } \\
\text { present? }\end{array}$ & Yes. Most locations. \\
\hline $\begin{array}{l}\text { If not, has the district } \\
\text { ever had zebra mussels } \\
\text { (in the past but died off } \\
\text {-may hint at cyclical } \\
\text { patterns)? }\end{array}$ & $\mathrm{N} / \mathrm{A}$ \\
\hline $\begin{array}{l}\text { How bad is the } \\
\text { infestation? Estimate } \\
\text { density and abundance } \\
\text { in the district. }\end{array}$ & $\begin{array}{l}\text { Brandon Road Lock \& Dam has a significant population } \\
\text { noticeable when dewatering. }\end{array}$ \\
\hline $\begin{array}{l}\text { On what surfaces do } \\
\text { they adhere? Are they } \\
\text { on the infrastructure, if } \\
\text { so where? }\end{array}$ & $\begin{array}{l}\text { They are found on the steel and concrete but not the rubber } \\
\text { seals. Also possibly around the MWRD controlled structures } \\
\text { near the lock (sluice gates). A lot are the on flooring mooring } \\
\text { bits and along bottom of the gates. Probably in the valve } \\
\text { tunnels. }\end{array}$ \\
\hline $\begin{array}{l}\text { Are zebra mussels } \\
\text { interfering with O\&M? If } \\
\text { so, at what cost? }\end{array}$ & $\begin{array}{l}\text { There is no increased maintenance specifically due to mussel } \\
\text { attachment, yet. }\end{array}$ \\
\hline $\begin{array}{l}\text { What methods are used } \\
\text { for mussel mitigation } \\
\text { (facility retrofit, } \\
\text { scraping, chemicals, jet } \\
\text { washing, desiccation)? }\end{array}$ & $\begin{array}{l}\text { Any attachment near submerged moving parts seem to be } \\
\text { crushed or swept off during operation. }\end{array}$ \\
\hline $\begin{array}{l}\text { What is an estimate of } \\
\text { down time due to zebra } \\
\text { mussel mitigation? }\end{array}$ & \\
\hline $\begin{array}{l}\text { Does your district take } \\
\text { any preventative } \\
\text { measures to deter zebra } \\
\text { mussels? }\end{array}$ & No \\
\hline $\begin{array}{l}\text { Please provide projects } \\
\text { impacted by zebra } \\
\text { mussels and a point of } \\
\text { contact }\end{array}$ & \\
\hline $\begin{array}{l}\text { Questionnaire: Detroit } \\
\text { LRE District }\end{array}$ & Answers \\
\hline $\begin{array}{l}\text { Are there zebra mussels } \\
\text { in your district? If so, at } \\
\text { which locations within } \\
\text { the district are they } \\
\text { present? }\end{array}$ & $\begin{array}{l}\text { Zebra mussels are found at many of our projects throughout } \\
\text { Lake Huron, Lake Michigan \& Lake Erie. More prevalent as } \\
\text { you move further south on the lakes. We have numerous } \\
\text { commercial/recreational harbors located on each lake, so we } \\
\text { are not listing them all, but typically will note the presence of } \\
\text { the mussels during routine O\&M activities. These projects } \\
\text { typically include navigation channels and coastal navigation } \\
\text { structures (breakwaters, piers, revetments). }\end{array}$ \\
\hline
\end{tabular}




\begin{tabular}{|c|c|}
\hline Questions & Answers \\
\hline $\begin{array}{l}\text { If not, has the district } \\
\text { ever had zebra mussels } \\
\text { (in the past but died off } \\
\text {-may hint at cyclical } \\
\text { patterns)? }\end{array}$ & $\begin{array}{l}\text { As we have never tracked any kind of definitive information, it } \\
\text { is difficult to say whether the prevalence has declined or } \\
\text { increased. }\end{array}$ \\
\hline $\begin{array}{l}\text { How bad is the } \\
\text { infestation? Estimate } \\
\text { density and abundance } \\
\text { in the district. }\end{array}$ & $\begin{array}{l}\text { We do not have any good estimates of density or abundance } \\
\text { and do not track any kind of data/observations. }\end{array}$ \\
\hline $\begin{array}{l}\text { On what surfaces do } \\
\text { they adhere? Are they } \\
\text { on the infrastructure, if } \\
\text { so where? }\end{array}$ & $\begin{array}{l}\text { They are typically observed adhered to armor stone, steel } \\
\text { sheet pile and timber cribbing on our navigation structures } \\
\text { (piers, breakwaters, revetments) }\end{array}$ \\
\hline $\begin{array}{l}\text { Are zebra mussels } \\
\text { interfering with O\&M? If } \\
\text { so, at what cost? }\end{array}$ & $\begin{array}{l}\text { They do not interfere with our routine O\&M as there is } \\
\text { minimal O\&M associated with these structures (due in part to } \\
\text { lack of funding, but also the nature of the structures - } \\
\text { minimal routine physical maintenance, and when required } \\
\text { you are talking replenishing/replacing stone, } \\
\text { repairing/replacing SSP due to damage, encapsulating } \\
\text { timber cribbing if accomplishing a major repair to those type } \\
\text { of structures). Presence of the mussels can interfere with } \\
\text { visual inspections - say by underwater ROV or divers. Our } \\
\text { projects do not include the type of infrastructure that can be } \\
\text { more seriously impacted, such as water intakes, water level } \\
\text { gages, etc. The possible exception being the Soo Locks } \\
\text { Complex, but the colder waters of Lake Superior seem to } \\
\text { deter the presence of the mussels. }\end{array}$ \\
\hline $\begin{array}{l}\text { What methods are used } \\
\text { for mussel mitigation } \\
\text { (facility retrofit, } \\
\text { scraping, chemicals, jet } \\
\text { washing, desiccation)? }\end{array}$ & $\begin{array}{l}\text { We do not pursue any work related specifically to removal of } \\
\text { mussels. As noted above, the presence of the mussels has } \\
\text { little to no impact on major maintenance when required. }\end{array}$ \\
\hline $\begin{array}{l}\text { What is an estimate of } \\
\text { down time due to zebra } \\
\text { mussel mitigation? }\end{array}$ & None \\
\hline $\begin{array}{l}\text { Does your district take } \\
\text { any preventative } \\
\text { measures to deter zebra } \\
\text { mussels? }\end{array}$ & No \\
\hline $\begin{array}{l}\text { Please provide projects } \\
\text { impacted by zebra } \\
\text { mussels and a point of } \\
\text { contact }\end{array}$ & \\
\hline
\end{tabular}


Table A-3. Questionnaire Responses: Huntington LRH District

\begin{tabular}{|c|c|}
\hline Questions & Answers \\
\hline $\begin{array}{l}\text { Are there zebra } \\
\text { mussels in your } \\
\text { district? If so, at } \\
\text { which locations } \\
\text { within the district are } \\
\text { they present? }\end{array}$ & $\begin{array}{l}\text { Yes. Historically have been discovered in high densities at Alum } \\
\text { Creek (1999), Dewey (2004) and Fishtrap (2009) Lakes. They } \\
\text { are present at all nine Navigation projects on the Ohio and } \\
\text { Kanawha Rivers as well. No significant populations have been } \\
\text { noted at other lakes, but they are likely present in low densities. }\end{array}$ \\
\hline $\begin{array}{l}\text { If not, has the district } \\
\text { ever had zebra } \\
\text { mussels (in the past } \\
\text { but died off -may hint } \\
\text { at cyclical patterns)? }\end{array}$ & N/A \\
\hline $\begin{array}{l}\text { How bad is the } \\
\text { infestation? Estimate } \\
\text { density and } \\
\text { abundance in the } \\
\text { district. }\end{array}$ & $\begin{array}{l}\text { See attached MFR. Densities seemed to have peaked around } \\
2007 \text { at Dewey Lake. Mussel densities were too high to } \\
\text { estimate. Dewey densities have significantly decreased since } \\
\text { 2007. No estimates on abundance have been made for the } \\
\text { District. }\end{array}$ \\
\hline $\begin{array}{l}\text { On what surfaces do } \\
\text { they adhere? Are } \\
\text { they on the } \\
\text { infrastructure, if so } \\
\text { where? }\end{array}$ & $\begin{array}{l}\text { They have adhered to gates, sills, cables, tunnels, boats, docks, } \\
\text { etc. }\end{array}$ \\
\hline $\begin{array}{l}\text { Are zebra mussels } \\
\text { interfering with } \\
\text { O\&M? If so, at what } \\
\text { cost? }\end{array}$ & $\begin{array}{l}\text { Infestations at Dewey Lake resulted in extra cleaning and } \\
\text { maintenance of gate structures. Zebra mussels significantly } \\
\text { clarified the lake creating a deeper epilimnion and a large } \\
\text { increase in submerged macrophytes. This interfered with our } \\
\text { Recreation mission (fishing, boating, etc.). }\end{array}$ \\
\hline $\begin{array}{l}\text { What methods are } \\
\text { used for mussel } \\
\text { mitigation (facility } \\
\text { retrofit, scraping, } \\
\text { chemicals, jet } \\
\text { washing, } \\
\text { desiccation)? }\end{array}$ & Regular exercising of outlet gates. \\
\hline $\begin{array}{l}\text { What is an estimate } \\
\text { of down time due to } \\
\text { zebra mussel } \\
\text { mitigation? }\end{array}$ & There was no down time for our flood control structures. \\
\hline $\begin{array}{l}\text { Does your district } \\
\text { take any preventative } \\
\text { measures to deter } \\
\text { zebra mussels? }\end{array}$ & No \\
\hline $\begin{array}{l}\text { Please provide } \\
\text { projects impacted by } \\
\text { zebra mussels and a } \\
\text { point of contact }\end{array}$ & $\begin{array}{l}\text { District - Andrew Johnson, Andrew.n.johnson@usace.army.mil } \\
\text { <mailto:Andrew.n.johnson@usace.army.mil> } \\
\text { Dewey - David Freeland, David.e.freeland@usace.army.mil } \\
\text { <mailto:David.e.freeland@usace.army.mil> } \\
\text { Fishtrap - Rodney Holbrook, Mark.r.holbrook@usace.army.mil } \\
\text { <mailto:Mark.r.holbrook@usace.army.mil> }\end{array}$ \\
\hline
\end{tabular}


Table A-4. Questionnaire Responses: Louisville LRL District.

\begin{tabular}{|c|c|}
\hline Questions & Answers \\
\hline $\begin{array}{l}\text { Are there zebra mussels in } \\
\text { your district? If so, at which } \\
\text { locations within the district } \\
\text { are they present? }\end{array}$ & $\begin{array}{l}\text { Yes at the Louisville District locks and dams and also Ohio } \\
\text { River at Ohio Falls Station. }\end{array}$ \\
\hline $\begin{array}{l}\text { If not, has the district ever } \\
\text { had zebra mussels (in the } \\
\text { past but died off -may hint } \\
\text { at cyclical patterns)? }\end{array}$ & $\mathrm{N} / \mathrm{A}$ \\
\hline \multicolumn{2}{|l|}{$\begin{array}{l}\text { How bad is the infestation? } \\
\text { Estimate density and } \\
\text { abundance in the district. }\end{array}$} \\
\hline $\begin{array}{l}\text { On what surfaces do they } \\
\text { adhere? Are they on the } \\
\text { infrastructure, if so where? }\end{array}$ & $\begin{array}{l}\text { Lock and dam surfaces, gaging stations and raw water } \\
\text { wells. }\end{array}$ \\
\hline $\begin{array}{l}\text { Are zebra mussels } \\
\text { interfering with } O \& M \text { ? If so, } \\
\text { at what cost? }\end{array}$ & $\begin{array}{l}\text { They inhibit the ability to inspect structures at times, but } \\
\text { can be brushed off easily enough when we inspect or } \\
\text { work on things. We (Markland L\&D, Ohio River) have seen } \\
\text { zebra mussels, but I would not say that it has had a } \\
\text { significant impact on the stations operations up to this } \\
\text { point (except for interfering with their water quality } \\
\text { sensors). }\end{array}$ \\
\hline $\begin{array}{l}\text { What methods are used for } \\
\text { mussel mitigation (facility } \\
\text { retrofit, scraping, } \\
\text { chemicals, jet washing, } \\
\text { desiccation)? }\end{array}$ & Scraping or brushing off, chlorine tablets. \\
\hline \multicolumn{2}{|l|}{$\begin{array}{l}\text { What is an estimate of } \\
\text { down time due to zebra } \\
\text { mussel mitigation? }\end{array}$} \\
\hline \multicolumn{2}{|l|}{$\begin{array}{l}\text { Does your district take any } \\
\text { preventative measures to } \\
\text { deter zebra mussels? }\end{array}$} \\
\hline $\begin{array}{l}\text { Please provide projects } \\
\text { impacted by zebra mussels } \\
\text { and a point of contact }\end{array}$ & $\begin{array}{l}\text { Cannelton and Smithland L\&D (Ohio River): Zebra } \\
\text { mussels are a primary pest. }\end{array}$ \\
\hline
\end{tabular}


Table A-5. Questionnaire Responses: Nashville LRN District.

\begin{tabular}{|c|c|}
\hline Questions & Answers \\
\hline $\begin{array}{l}\text { Are there zebra mussels in } \\
\text { your district? If so, at which } \\
\text { locations within the district } \\
\text { are they present? }\end{array}$ & $\begin{array}{l}\text { In the Cumberland River, zebra mussels have been } \\
\text { observed in low numbers downstream from Old Hickory } \\
\text { Dam (CRM 216.2). A single zebra mussel was documented } \\
\text { in } 1999 \text { at CRM 306.3, near the upper end of Old Hickory } \\
\text { Reservoir. Further upstream, the only confirmed occurrence } \\
\text { was at the Conley Bottom Marina on Lake Cumberland. }\end{array}$ \\
\hline $\begin{array}{l}\text { If not, has the district ever } \\
\text { had zebra mussels (in the } \\
\text { past but died off -may hint at } \\
\text { cyclical patterns)? }\end{array}$ & $\begin{array}{l}\text { Based on available records, zebra mussels have been } \\
\text { documented in the Tennessee River since circa } 1990 \text {. By } \\
\text { late } 2001 \text {, there were potentially significant increases in } \\
\text { the population density of zebra mussels in several upper } \\
\text { Tennessee River locations. There were large populations } \\
\text { below Chickamauga Dam, within Watts Bar Reservoir, and } \\
\text { below Watts Bar Dam. Densities in these areas ranged from } \\
600 \text { to over } 23,000 \text { per square meter. Compared to the } \\
\text { upper reaches of the Tennessee River, the middle and lower } \\
\text { reaches of the Tennessee River had very low zebra mussel } \\
\text { densities. Maximum site density in Kentucky Lake, for } \\
\text { example, was } 0.05 \text { mussels per square meter. A survey } \\
\text { conducted in conjunction with the } 2002 \text { Wheeler Lock } \\
\text { chamber dewatering revealed an estimated } 200 \text { zebra } \\
\text { mussels per square meter in the upper end of the lock and } \\
10 \text { per square meter in the lower end of the lock. These } \\
\text { populations apparently did/do not impact Corps missions }\end{array}$ \\
\hline $\begin{array}{l}\text { How bad is the infestation? } \\
\text { Estimate density and } \\
\text { abundance in the district. }\end{array}$ & $\begin{array}{l}\text { When Barkley Lock (KY) was dewatered in } 2001 \text {, a survey } \\
\text { revealed mussel densities of less than } 1 \text { per square meter. }\end{array}$ \\
\hline \multicolumn{2}{|l|}{$\begin{array}{l}\text { On what surfaces do they } \\
\text { adhere? Are they on the } \\
\text { infrastructure, if so where? }\end{array}$} \\
\hline $\begin{array}{l}\text { Are zebra mussels interfering } \\
\text { with } O \& M ? \text { If so, at what cost? }\end{array}$ & $\begin{array}{l}\text { Nashville District has no known current or potential future } \\
\text { impacts to our hydropower projects due to aquatic invasive } \\
\text { species, i.e. zebra mussels. }\end{array}$ \\
\hline $\begin{array}{l}\text { What methods are used for } \\
\text { mussel mitigation (facility } \\
\text { retrofit, scraping, chemicals, } \\
\text { jet washing, desiccation)? }\end{array}$ & $\begin{array}{l}\text { Chlorination strategies as a control technology were } \\
\text { abandoned sometime after } 2002 \text { due to the lack of zebra } \\
\text { mussel fouling problems at Nashville District facilities. }\end{array}$ \\
\hline \multicolumn{2}{|l|}{$\begin{array}{l}\text { What is an estimate of down } \\
\text { time due to zebra mussel } \\
\text { mitigation? }\end{array}$} \\
\hline $\begin{array}{l}\text { Does your district take any } \\
\text { preventative measures to } \\
\text { deter zebra mussels? }\end{array}$ & $\begin{array}{l}\text { Hydropower plants at Barkley and Cheatham Dams have } \\
\text { discontinued regular zebra mussel veliger monitoring } \\
\text { although the infrastructure is in place to conduct future } \\
\text { monitoring, if deemed necessary. This is due to the fact } \\
\text { that past veliger monitoring had never revealed numbers } \\
\text { that reached a level that would indicate a significant } \\
\text { increase nor a potential fouling problem. }\end{array}$ \\
\hline $\begin{array}{l}\text { Please provide projects } \\
\text { impacted by zebra mussels } \\
\text { and a point of contact }\end{array}$ & \\
\hline
\end{tabular}


Table A-6. Questionnaire Responses: Pittsburgh LRP District.

\begin{tabular}{|c|c|}
\hline Questions & Answers \\
\hline $\begin{array}{l}\text { Are there zebra mussels } \\
\text { in your district? If so, at } \\
\text { which locations within the } \\
\text { district are they present? }\end{array}$ & $\begin{array}{l}\text { Yes. Allegheny, Ohio and Monongahela River Locks, Kinzua } \\
\& \text { Allegheny Reservoir, Berlin Lake, Mosquito Creek Lake. } \\
\text { We've documented zebra mussel infestations at Berlin, } \\
\text { Kirwan, and Mosquito Creek Lakes, and also at every } \\
\text { navigation dam. }\end{array}$ \\
\hline $\begin{array}{l}\text { If not, has the district ever } \\
\text { had zebra mussels (in the } \\
\text { past but died off -may hint } \\
\text { at cyclical patterns)? }\end{array}$ & $\begin{array}{l}\text { According to our Water Quality Biologist, around } \\
2010 / 2011 \text { the zebra mussel population crashed } \\
\text { throughout the District. Prior to 2008, we had problems } \\
\text { with zebra mussels at the navigation dams and Mosquito } \\
\text { Creek Lake in particular. For example, a } 2007 \text { photo of a } \\
\text { Mosquito trash rack is attached; the Warren water supply } \\
\text { intake was also completely clogged. However, around } 2010 \\
\text { or 2011, it appeared that the zebra population crashed } \\
\text { throughout the District. While populations have recovered, I } \\
\text { don't think that they are as dense as they were }\end{array}$ \\
\hline $\begin{array}{l}\text { How bad is the } \\
\text { infestation? Estimate } \\
\text { density and abundance in } \\
\text { the district. }\end{array}$ & Much less than in years prior to 2010. \\
\hline $\begin{array}{l}\text { On what surfaces do they } \\
\text { adhere? Are they on the } \\
\text { infrastructure, if so } \\
\text { where? }\end{array}$ & $\begin{array}{l}\text { See attached photo. Also, lock walls, floating mooring bitts, } \\
\text { intakes. }\end{array}$ \\
\hline $\begin{array}{l}\text { Are zebra mussels } \\
\text { interfering with O\&M? If } \\
\text { so, at what cost? }\end{array}$ & $\begin{array}{l}\text { I have not had any reports of it, but did not get much } \\
\text { feedback. }\end{array}$ \\
\hline $\begin{array}{l}\text { What methods are used } \\
\text { for mussel mitigation } \\
\text { (facility retrofit, scraping, } \\
\text { chemicals, jet washing, } \\
\text { desiccation)? }\end{array}$ & Unsure. \\
\hline $\begin{array}{l}\text { What is an estimate of } \\
\text { down time due to zebra } \\
\text { mussel mitigation? }\end{array}$ & \\
\hline $\begin{array}{l}\text { Does your district take } \\
\text { any preventative } \\
\text { measures to deter zebra } \\
\text { mussels? }\end{array}$ & \\
\hline $\begin{array}{l}\text { Please provide projects } \\
\text { impacted by zebra } \\
\text { mussels and a point of } \\
\text { contact }\end{array}$ & $\begin{array}{l}\text { Contact Rose Reilly at } 412-395-7357 \text { or Tom Maier at } 412- \\
395-7219 \text { for additional information. They are the best } \\
\text { source of information on this topic. }\end{array}$ \\
\hline
\end{tabular}




\section{A.2 Mississippi Valley Division*}

Table A-7. Questionnaire Responses: Memphis MVM District.

\begin{tabular}{|l|l|}
\hline Questions & Answers \\
\hline $\begin{array}{l}\text { Are there zebra mussels in your district? If } \\
\text { so, at which locations within the district are } \\
\text { they present? }\end{array}$ & $\begin{array}{l}\text { Yes, Lower Mississippi River and Lower } \\
\text { Ohio River. }\end{array}$ \\
\hline $\begin{array}{l}\text { If not, has the district ever had zebra } \\
\text { mussels (in the past but died off -may hint } \\
\text { at cyclical patterns)? }\end{array}$ & \\
\hline $\begin{array}{l}\text { How bad is the infestation? Estimate } \\
\text { density and abundance in the district. }\end{array}$ & $\begin{array}{l}\text { Most of our experience with zebra } \\
\text { mussels is illustrated in the attached } \\
\text { im the infrastructure, if so where? }\end{array}$ \\
\hline $\begin{array}{l}\text { Are zebra mussels interfering with O\&M? } \text { mols attached to ACM } \\
\text { so, at what cost? }\end{array}$ & Not known \\
\hline $\begin{array}{l}\text { What methods are used for mussel } \\
\text { mitigation (facility retrofit, scraping, } \\
\text { chemicals, jet washing, desiccation)? }\end{array}$ & \\
\hline $\begin{array}{l}\text { What is an estimate of down time due to } \\
\text { zebra mussel mitigation? }\end{array}$ & \\
\hline $\begin{array}{l}\text { Does your district take any preventative } \\
\text { measures to deter zebra mussels? }\end{array}$ & Monitoring. \\
\hline $\begin{array}{l}\text { Please provide projects impacted by zebra } \\
\text { mussels and a point of contact }\end{array}$ & \\
\hline
\end{tabular}

* Note: There were no responses from St. Louis MVS and minimal responses from Memphis and Vicksburg. 
Table A-8. Questionnaire Responses: New Orleans MVN District.

\begin{tabular}{|l|l|}
\hline Questions & Answers \\
\hline $\begin{array}{l}\text { Are there zebra mussels in } \\
\text { your district? If so, at which } \\
\text { locations within the district } \\
\text { are they present? }\end{array}$ & $\begin{array}{l}\text { Yes we do have zebra mussels, but they do not cause } \\
\text { too much of a problem }\end{array}$ \\
\hline $\begin{array}{l}\text { If not, has the district ever } \\
\text { had zebra mussels (in the } \\
\text { past but died off -may hint at } \\
\text { cyclical patterns)? }\end{array}$ & \\
\hline $\begin{array}{l}\text { How bad is the infestation? } \\
\text { Estimate density and } \\
\text { abundance in the district. }\end{array}$ & \\
\hline $\begin{array}{l}\text { On what surfaces do they } \\
\text { adhere? Are they on the } \\
\text { infrastructure, if so where? }\end{array}$ & \\
\hline $\begin{array}{l}\text { Are zebra mussels interfering } \\
\text { with O\&M? If so, at what } \\
\text { cost? }\end{array}$ & $\begin{array}{l}\text { Not much attention on mussels lately. Many of our } \\
\text { structures are in coastal areas where the saltwater } \\
\text { reduces excessive infestation. In those areas, I've seen } \\
\text { oyster attachment to be much greater than zebra } \\
\text { mussel attachment. }\end{array}$ \\
\hline $\begin{array}{l}\text { What methods are used for } \\
\text { mussel mitigation (facility } \\
\text { retrofit, scraping, chemicals, } \\
\text { jet washing, desiccation)? }\end{array}$ & \\
\hline $\begin{array}{l}\text { What is an estimate of down } \\
\text { time due to zebra mussel } \\
\text { mitigation? }\end{array}$ & \\
\hline $\begin{array}{l}\text { Does your district take any } \\
\text { preventative measures to } \\
\text { deter zebra mussels? }\end{array}$ & \\
\hline $\begin{array}{l}\text { Please provide projects } \\
\text { impacted by zebra mussels } \\
\text { and a point of contact }\end{array}$ & $\begin{array}{l}\text { Russell Beauvais - Old River Control - Miss and Atch } \\
\text { Rivers, Vic Landry - GIWW - New Orleans to Calcasieu } \\
\text { Lock, Tim Connell - Atchafalaya Basin, Tracy Falk - SW } \\
\text { Louisiana saltwater control structures, Ray Newman - } \\
\text { Bonnet Carre Spillway, New Orleans flood control } \\
\text { structures and outlets }\end{array}$ \\
\hline
\end{tabular}


Table A-9. Questionnaire Responses: Rock Island MVR District

\begin{tabular}{|c|c|}
\hline Questions & Answers \\
\hline $\begin{array}{l}\text { Are there zebra mussels } \\
\text { in your district? If so, at } \\
\text { which locations within } \\
\text { the district are they } \\
\text { present? }\end{array}$ & $\begin{array}{l}\text { Yes. Pretty much everywhere in the district but not as } \\
\text { abundant as they used to be in the } 1990 \text { s. Most in the Illinois } \\
\text { waterway (the original "epicenter" of the problem) but now } \\
\text { not much anymore and they are hard to find. They don't know } \\
\text { exactly why that is the case but they suspect things like water } \\
\text { temperature (mentioned Lake Pepin temperature). Same with } \\
\text { the Mississippi River - much less abundant and population is } \\
\text { stabilized. }\end{array}$ \\
\hline \multicolumn{2}{|l|}{$\begin{array}{l}\text { If not, has the district } \\
\text { ever had zebra mussels } \\
\text { (in the past but died off } \\
\text {-may hint at cyclical } \\
\text { patterns)? }\end{array}$} \\
\hline $\begin{array}{l}\text { How bad is the } \\
\text { infestation? Estimate } \\
\text { density and abundance } \\
\text { in the district. }\end{array}$ & Should contact Dan Kelner (MVP) for population numbers. \\
\hline $\begin{array}{l}\text { On what surfaces do } \\
\text { they adhere? Are they } \\
\text { on the infrastructure, if } \\
\text { so where? }\end{array}$ & concrete \\
\hline $\begin{array}{l}\text { Are zebra mussels } \\
\text { interfering with O\&M? If } \\
\text { so, at what cost? }\end{array}$ & $\begin{array}{l}\text { they have tried to quantify the impact of zebra mussels many } \\
\text { times for cost and operation/maintenance and it's really hard } \\
\text { to do and is all over the board, and it's as if there is no direct } \\
\text { impact but it could be a tax on the system such as eroding } \\
\text { the concrete faster than it should so that it would need to be } \\
\text { replaced or repaired more quickly. Should contact Courtney } \\
\text { Chambers for cost figures, if they exist. }\end{array}$ \\
\hline \multicolumn{2}{|l|}{$\begin{array}{l}\text { What methods are used } \\
\text { for mussel mitigation } \\
\text { (facility retrofit, } \\
\text { scraping, chemicals, jet } \\
\text { washing, desiccation)? }\end{array}$} \\
\hline \multicolumn{2}{|l|}{$\begin{array}{l}\text { What is an estimate of } \\
\text { down time due to zebra } \\
\text { mussel mitigation? }\end{array}$} \\
\hline $\begin{array}{l}\text { Does your district take } \\
\text { any preventative } \\
\text { measures to deter zebra } \\
\text { mussels? }\end{array}$ & Monitoring in Cordova, IL. \\
\hline $\begin{array}{l}\text { Please provide projects } \\
\text { impacted by zebra } \\
\text { mussels and a point of } \\
\text { contact }\end{array}$ & \\
\hline
\end{tabular}


Table A-10. Questionnaire Responses: St. Paul MVP District.

\begin{tabular}{|c|c|}
\hline Questions & Answers \\
\hline $\begin{array}{l}\text { Are there zebra mussels in } \\
\text { your district? If so, at } \\
\text { which locations within the } \\
\text { district are they present? }\end{array}$ & $\begin{array}{l}\text { Yes. Gull Lake, Cross Lake Dam, Pine River Dam. Zebra } \\
\text { mussels present in the Mississippi River primarily } \\
\text { downstream of Lake Pepin in Pool } 4 \text {. Zebra mussels } \\
\text { present at Locks and Dams } 4-10 .\end{array}$ \\
\hline \multicolumn{2}{|l|}{$\begin{array}{l}\text { If not, has the district ever } \\
\text { had zebra mussels (in the } \\
\text { past but died off -may hint } \\
\text { at cyclical patterns)? }\end{array}$} \\
\hline $\begin{array}{l}\text { How bad is the } \\
\text { infestation? Estimate } \\
\text { density and abundance in } \\
\text { the district. }\end{array}$ & $\begin{array}{l}\text { Zebra mussel densities within the Mississippi River below } \\
\text { Lake Pepin have exceed } 10,000 / \mathrm{m}^{2} \text { in the early } 2000 \text { s in } \\
\text { many areas. Populations have somewhat leveled off at } \\
\text { lower levels below }<1,000 / \mathrm{m}^{2} \text { but population densities are } \\
\text { highly variable and are cyclic with annual summer die-offs } \\
\text { followed by large recruitment of new individuals in fall and } \\
\text { spring. }\end{array}$ \\
\hline $\begin{array}{l}\text { On what surfaces do they } \\
\text { adhere? Are they on the } \\
\text { infrastructure, if so where? }\end{array}$ & Gate's skin plate and concrete piers. \\
\hline $\begin{array}{l}\text { Are zebra mussels } \\
\text { interfering with } 0 \& M ? \text { If } \\
\text { so, at what cost? }\end{array}$ & $\begin{array}{l}\text { Just had a recent incident at Gull Lake, MN where they } \\
\text { opened a gate on a dam and couldn't close it due to Zebra } \\
\text { Mussels. }\end{array}$ \\
\hline $\begin{array}{l}\text { What methods are used } \\
\text { for mussel mitigation } \\
\text { (facility retrofit, scraping, } \\
\text { chemicals, jet washing, } \\
\text { desiccation)? }\end{array}$ & $\begin{array}{l}\text { Empty zebra mussel shells dredged from lock chambers } \\
\text { and disposed of. }\end{array}$ \\
\hline \multicolumn{2}{|l|}{$\begin{array}{l}\text { What is an estimate of } \\
\text { down time due to zebra } \\
\text { mussel mitigation? }\end{array}$} \\
\hline \multicolumn{2}{|l|}{$\begin{array}{l}\text { Does your district take any } \\
\text { preventative measures to } \\
\text { deter zebra mussels? }\end{array}$} \\
\hline $\begin{array}{l}\text { Please provide projects } \\
\text { impacted by zebra } \\
\text { mussels and a point of } \\
\text { contact }\end{array}$ & \\
\hline
\end{tabular}


Table A-11. Questionnaire Responses: Vicksburg MVH District.

\begin{tabular}{|l|l|}
\hline Questions & Answers \\
\hline $\begin{array}{l}\text { Are there zebra mussels in your district? If } \\
\text { so, at which locations within the district } \\
\text { are they present? }\end{array}$ & Yes - photos sent. \\
\hline $\begin{array}{l}\text { If not, has the district ever had zebra } \\
\text { mussels (in the past but died off -may } \\
\text { hint at cyclical patterns)? }\end{array}$ & \\
\hline $\begin{array}{l}\text { How bad is the infestation? Estimate } \\
\text { density and abundance in the district. }\end{array}$ & \\
\hline $\begin{array}{l}\text { On what surfaces do they adhere? Are } \\
\text { they on the infrastructure, if so where? }\end{array}$ & Concrete walls. \\
\hline $\begin{array}{l}\text { Are zebra mussels interfering with O\&M? } \\
\text { If so, at what cost? }\end{array}$ & $\begin{array}{l}\text { l'm (KC Ellis) involved in maintenance on } \\
\text { nine locks and dams, no recent activity } \\
\text { except \#3 lock and dam on Red River. }\end{array}$ \\
\hline $\begin{array}{l}\text { What methods are used for mussel } \\
\text { mitigation (facility retrofit, scraping, } \\
\text { chemicals, jet washing, desiccation)? }\end{array}$ & \\
\hline $\begin{array}{l}\text { What is an estimate of down time due to } \\
\text { zebra mussel mitigation? }\end{array}$ & \\
\hline $\begin{array}{l}\text { Does your district take any preventative } \\
\text { measures to deter zebra mussels? }\end{array}$ & \\
\hline $\begin{array}{l}\text { Please provide projects impacted by } \\
\text { zebra mussels and a point of contact }\end{array}$ & \\
\hline
\end{tabular}




\section{A.3 North Atlantic Division*}

Table A-12. Questionnaire Responses: Baltimore NAB District.

\begin{tabular}{|c|c|}
\hline Questions & Answers \\
\hline $\begin{array}{l}\text { Are there zebra mussels } \\
\text { in your district? If so, at } \\
\text { which locations within the } \\
\text { district are they present? }\end{array}$ & $\begin{array}{l}\text { Zebra mussels have been identified at Cowanesque Lake in } \\
\text { Tioga County, Pennsylvania, and Curwensville Lake in } \\
\text { Clearfield County, Pennsylvania. }\end{array}$ \\
\hline $\begin{array}{l}\text { If not, has the district ever } \\
\text { had zebra mussels (in the } \\
\text { past but died off -may hint } \\
\text { at cyclical patterns)? }\end{array}$ & N/A \\
\hline $\begin{array}{l}\text { How bad is the } \\
\text { infestation? Estimate } \\
\text { density and abundance in } \\
\text { the district. }\end{array}$ & $\begin{array}{l}\text { The density and abundance of zebra mussels at both lakes } \\
\text { would be characterized as low and sparse. The populations } \\
\text { at both Curwensville Lake and Cowanesque Lake have been } \\
\text { on the decline over the last few years. }\end{array}$ \\
\hline $\begin{array}{l}\text { On what surfaces do they } \\
\text { adhere? Are they on the } \\
\text { infrastructure, if so } \\
\text { where? }\end{array}$ & $\begin{array}{l}\text { @ Curwensville Lake - zebra mussels were previously seen } \\
\text { along the shoreline and on concrete trash racks. This year, } \\
\text { no zebra mussels have been observed. } \\
\text { @ Cowanesque Lake - zebra mussels have been observed } \\
\text { adhering to the underside of beach and navigational buoys } \\
\text { when the buoys were removed in the Fall. Very few mussels } \\
\text { were found last Fall when the buoys were removed. Zebra } \\
\text { Mussels have also been observed adhering to the concrete } \\
\text { walls inside of wet wells. However, during the most recent } \\
\text { wet well inspection, coverage has declined to }<5 \% \text { on the } \\
\text { concrete walls inside the wet wells. }\end{array}$ \\
\hline $\begin{array}{l}\text { Are zebra mussels } \\
\text { interfering with } O \& M \text { ? If } \\
\text { so, at what cost? }\end{array}$ & No \\
\hline $\begin{array}{l}\text { What methods are used } \\
\text { for mussel mitigation } \\
\text { (facility retrofit, scraping, } \\
\text { chemicals, jet washing, } \\
\text { desiccation)? }\end{array}$ & $\begin{array}{l}\text { Monitoring is performed during routine inspections at both } \\
\text { lakes, but no mitigation efforts are required or being } \\
\text { performed at this time. }\end{array}$ \\
\hline $\begin{array}{l}\text { What is an estimate of } \\
\text { down time due to zebra } \\
\text { mussel mitigation? }\end{array}$ & No down time has occurred. \\
\hline $\begin{array}{l}\text { Does your district take } \\
\text { any preventative } \\
\text { measures to deter zebra } \\
\text { mussels? }\end{array}$ & $\begin{array}{l}\text { Both projects display informational signs to deter boaters } \\
\text { from transporting zebra mussels and other invasives into } \\
\text { and out of the lakes. }\end{array}$ \\
\hline $\begin{array}{l}\text { Please provide projects } \\
\text { impacted by zebra } \\
\text { mussels and a point of } \\
\text { contact }\end{array}$ & $\begin{array}{l}\text { - Cowanesque Lake - Steve Sporer, head ranger (570) 835- } \\
\text { 5281; } \\
\text { - Curwensville Lake - Tim Smay, head dam operator (814) } \\
\text { 236-2000; } \\
\text { - Baltimore District Office - Phil Cwiek Natural Resources } \\
\text { Management Specialist (410) 962-6010. }\end{array}$ \\
\hline
\end{tabular}

* Note that no responses were received from New York NAN and Norfolk NAO Districts and minimal response from Philadelphia. 
Table A-13. Questionnaire Responses: New England NAE District.

\begin{tabular}{|l|l|}
\hline Questions & Answers \\
\hline $\begin{array}{l}\text { Are there zebra mussels in } \\
\text { your district? If so, at which } \\
\text { locations within the district } \\
\text { are they present? }\end{array}$ & Yes. \\
\hline $\begin{array}{l}\text { If not, has the district ever } \\
\text { had zebra mussels (in the } \\
\text { past but died off -may hint at } \\
\text { cyclical patterns)? }\end{array}$ & N/A \\
\hline $\begin{array}{l}\text { How bad is the infestation? } \\
\text { Estimate density and }\end{array}$ & Minimal infestation. \\
\hline $\begin{array}{l}\text { On what surfaces do they } \\
\text { adhere? Are they on the } \\
\text { infrastructure, if so where? }\end{array}$ & $\begin{array}{l}\text { Concrete, steel, aluminum. Seem to attach to everything } \\
\text { submerged, like structures and equipment. Navigation } \\
\text { gate safety railings, top gate access hatches, and on the } \\
\text { two navigation gate lifting arms. They also attached to } \\
\text { the gate sill and gate pedestals on the bottom of the } \\
\text { channel. }\end{array}$ \\
\hline $\begin{array}{l}\text { Are zebra mussels interfering } \\
\text { with O\&M? If so, at what } \\
\text { cost? }\end{array}$ & $\begin{array}{l}\text { Yes, it is a recurring maintenance item about three times } \\
\text { per year. They do also minimally effect corrosion and the } \\
\text { functionality of water level sensors. }\end{array}$ \\
\hline $\begin{array}{l}\text { What methods are used for } \\
\text { mussel mitigation (facility } \\
\text { retrofit, scraping, chemicals, } \\
\text { jet washing, desiccation)? }\end{array}$ & $\begin{array}{l}\text { Removed by scraping. Also tried pressure washing, but it } \\
\text { was not very effective. }\end{array}$ \\
\hline $\begin{array}{l}\text { What is an estimate of down } \\
\text { time due to zebra mussel } \\
\text { mitigation? }\end{array}$ & $\begin{array}{l}\text { Does your district take any } \\
\text { preventative measures to } \\
\text { deter zebra mussels? }\end{array}$ \\
\hline $\begin{array}{l}\text { Please provide projects } \\
\text { impacted by zebra mussels } \\
\text { and a point of contact }\end{array}$ & $\begin{array}{l}\text { The City of Stamford does perform mussel removal in } \\
\text { their treatment plant discharge channel once a year } \\
\text { (takes } ~ 6 \text { hours). }\end{array}$ \\
\hline
\end{tabular}


Table A-14. Questionnaire Responses: New York NAN District.

\begin{tabular}{|l|l|}
\hline Questions & Answers \\
\hline $\begin{array}{l}\text { Are there zebra mussels in your } \\
\text { district? If so, at which locations } \\
\text { within the district are they } \\
\text { present? }\end{array}$ & $\begin{array}{l}\text { Don't have USACE facilities with a FRM, Recreation, } \\
\text { or Env Stewardship mission or component. Typically } \\
\text { in these districts we are looking at harbors or nav } \\
\text { channels that don't fit the FRM function. }\end{array}$ \\
\hline $\begin{array}{l}\text { If not, has the district ever had } \\
\text { zebra mussels (in the past but } \\
\text { died off -may hint at cyclical } \\
\text { patterns)? }\end{array}$ & \\
\hline $\begin{array}{l}\text { How bad is the infestation? } \\
\text { Estimate density and abundance } \\
\text { in district. }\end{array}$ & \\
\hline $\begin{array}{l}\text { On what surfaces do they adhere? } \\
\text { Are they on the infrastructure, if } \\
\text { so where? }\end{array}$ & \\
\hline $\begin{array}{l}\text { Are zebra mussels interfering with } \\
\text { O\&M? If so, at what cost? }\end{array}$ & \\
\hline $\begin{array}{l}\text { What methods are used for } \\
\text { mussel mitigation (facility retrofit, } \\
\text { scraping, chemicals, jet washing, } \\
\text { desiccation)? }\end{array}$ & \\
\hline $\begin{array}{l}\text { What is an estimate of down time } \\
\text { due to zebra mussel mitigation? }\end{array}$ & \\
\hline $\begin{array}{l}\text { Does your district take any } \\
\text { preventative measures to deter } \\
\text { zebra mussels? }\end{array}$ & \\
\hline $\begin{array}{l}\text { Please provide projects impacted } \\
\text { by zebra mussels and a point of } \\
\text { contact }\end{array}$ & \\
\hline
\end{tabular}


Table A-15. Questionnaire Responses: Norfolk NAO District.

\begin{tabular}{|l|l|}
\hline Questions & Answers \\
\hline $\begin{array}{l}\text { Are there zebra mussels in your } \\
\text { district? If so, at which locations } \\
\text { within the district are they } \\
\text { present? }\end{array}$ & $\begin{array}{l}\text { Don't have USACE facilities with a FRM, Recreation, } \\
\text { or Env Stewardship mission or component. Typically } \\
\text { in these districts we are looking at harbors or nav } \\
\text { channels that don't fit the FRM function. }\end{array}$ \\
\hline $\begin{array}{l}\text { If not, has the district ever had } \\
\text { zebra mussels (in the past but } \\
\text { died off -may hint at cyclical } \\
\text { patterns)? }\end{array}$ & \\
\hline $\begin{array}{l}\text { How bad is the infestation? } \\
\text { in the district. }\end{array}$ & \\
\hline $\begin{array}{l}\text { On what surfaces do they adhere? } \\
\text { Are they on the infrastructure, if } \\
\text { so where? }\end{array}$ & \\
\hline $\begin{array}{l}\text { Are zebra mussels interfering with } \\
\text { O\&M? If so, at what cost? }\end{array}$ & \\
\hline $\begin{array}{l}\text { What methods are used for } \\
\text { mussel mitigation (facility retrofit, } \\
\text { scraping, chemicals, jet washing, } \\
\text { desiccation)? }\end{array}$ & \\
\hline $\begin{array}{l}\text { What is an estimate of down time } \\
\text { due to zebra mussel mitigation? }\end{array}$ & \\
\hline $\begin{array}{l}\text { Does your district take any } \\
\text { preventative measures to deter } \\
\text { zebra mussels? }\end{array}$ & \\
\hline $\begin{array}{l}\text { Please provide projects impacted } \\
\text { by zebra mussels and a point of } \\
\text { contact }\end{array}$ & \\
\hline
\end{tabular}


Table A-16. Questionnaire Responses: Philadelphia NAP District.

\begin{tabular}{|l|l|}
\hline Questions & Answers \\
\hline $\begin{array}{l}\text { Are there zebra mussels } \\
\text { in your district? If so, at } \\
\text { which locations within the } \\
\text { district are they present? }\end{array}$ & Yes, Blue Marsh Lake. \\
\hline $\begin{array}{l}\text { If not, has the district ever } \\
\text { had zebra mussels (in the } \\
\text { past but died off -may hint } \\
\text { at cyclical patterns)? }\end{array}$ & \\
\hline $\begin{array}{l}\text { How bad is the } \\
\text { infestation? Estimate } \\
\text { density and abundance in } \\
\text { the district. }\end{array}$ & \\
\hline $\begin{array}{l}\text { On what surfaces do they } \\
\text { adhere? Are they on the } \\
\text { infrastructure, if so } \\
\text { where? }\end{array}$ & \\
\hline $\begin{array}{l}\text { Are zebra mussels } \\
\text { interfering with O\&M? If } \\
\text { so, at what cost? }\end{array}$ & \\
\hline $\begin{array}{l}\text { What methods are used } \\
\text { for mussel mitigation } \\
\text { (facility retrofit, scraping, } \\
\text { chemicals, jet washing, } \\
\text { desiccation)? }\end{array}$ & \\
\hline $\begin{array}{l}\text { What is an estimate of } \\
\text { down time due to zebra } \\
\text { mussel mitigation? }\end{array}$ & \\
\hline $\begin{array}{l}\text { Does your district take any } \\
\text { preventative measures to } \\
\text { deter zebra mussels? }\end{array}$ & Blue Marsh Lake has a monitoring program. \\
\hline $\begin{array}{l}\text { Please provide projects } \\
\text { impacted by zebra } \\
\text { mussels and a point of } \\
\text { contact }\end{array}$ & \begin{tabular}{l} 
\\
\hline
\end{tabular} \\
\hline
\end{tabular}




\section{A.4 Northwestern Division*}

Table A-17. Questionnaire Responses: Kansas City NWK District.

\begin{tabular}{|l|l|}
\hline Questions & Answers \\
\hline $\begin{array}{l}\text { Are there zebra mussels in } \\
\text { your district? If so, at } \\
\text { which locations within the } \\
\text { district are they present? }\end{array}$ & $\begin{array}{l}\text { Yes. Zebra mussel populations are currently found at both } \\
\text { our Smithville Lake Project and Truman Lake Project in } \\
\text { Missouri, Clinton Lake Project, Kanopolis Lake Project, } \\
\text { Melvern Lake Project, Milford Lake Project, Pomona Lake } \\
\text { Project, Perry Lake Project, Wilson Lake Project in Kansas, } \\
\text { Rathbun Lake Project in lowa, and the Missouri River }\end{array}$ \\
\hline $\begin{array}{l}\text { If not, has the district ever } \\
\text { had zebra mussels (in the } \\
\text { past but died off -may hint } \\
\text { at cyclical patterns)? }\end{array}$ & \\
\hline $\begin{array}{l}\text { How bad is the } \\
\text { infestation? Estimate } \\
\text { density and abundance in } \\
\text { the district. }\end{array}$ & $\begin{array}{l}\text { Each of these waterbodies are currently classified as } \\
\text { infested. Zebra mussel concentrations are being observed } \\
\text { on water intakes, the dams and appurtenant structures. }\end{array}$ \\
\hline $\begin{array}{l}\text { On what surfaces do they } \\
\text { adhere? Are they on the } \\
\text { infrastructure, if so where? }\end{array}$ & \\
\hline $\begin{array}{l}\text { Are zebra mussels } \\
\text { interfering with O\&M? If } \\
\text { so, at what cost? }\end{array}$ & $\begin{array}{l}\text { As these populations are fairly new we have not had } \\
\text { serious problems during operation, maintenance, } \\
\text { inspection and rehabilitation efforts but we remain very } \\
\text { concerned about zebra mussels increasing costs and } \\
\text { impeding operation and maintenance of these facilities } \\
\text { based on experience in other parts of the country. }\end{array}$ \\
\hline $\begin{array}{l}\text { What methods are used } \\
\text { preventative measures to } \\
\text { deter zebra mussels? }\end{array}$ & \\
\hline $\begin{array}{l}\text { Please provide projects } \\
\text { mussels and a point of } \\
\text { contact }\end{array}$ & \\
$\begin{array}{l}\text { (facility retrofit, scraping, } \\
\text { chemicals, jet washing, } \\
\text { desiccation)? }\end{array}$ & \\
\hline $\begin{array}{l}\text { What is an estimate of } \\
\text { mussel mitigation? }\end{array}$ & \\
\hline
\end{tabular}

\footnotetext{
* Note that no responses were received from Seattle NWS, however Spencer Heinz (NWP) indicated that there are no zebra mussel incidents in entire NWD except maybe the USGS dot in Montana and the Missouri River (NWK). The NWK response included much more than the Missouri River.
} 
Table A-18. Questionnaire Responses: Omaha NWO District.

\begin{tabular}{|c|c|}
\hline Questions & Answers \\
\hline $\begin{array}{l}\text { Are there zebra mussels } \\
\text { in your district? If so, at } \\
\text { which locations within } \\
\text { the district are they } \\
\text { present? }\end{array}$ & $\begin{array}{l}\text { Our Dam (Fort Randall) does not have mussels or clams YET, } \\
\text { but the Dam below us (Gavins Point Dam) does. So, yes. We } \\
\text { will likely have them soon in any raw water piping that } \\
\text { comes off of our penstocks.... heat exchangers, chillers, etc. } \\
\text { (at Fort Randall Dam) }\end{array}$ \\
\hline $\begin{array}{l}\text { If not, has the district } \\
\text { ever had zebra mussels } \\
\text { (in the past but died off - } \\
\text { may hint at cyclical } \\
\text { patterns)? }\end{array}$ & No. \\
\hline $\begin{array}{l}\text { How bad is the } \\
\text { infestation? Estimate } \\
\text { density and abundance } \\
\text { in the district. }\end{array}$ & \\
\hline $\begin{array}{l}\text { On what surfaces do they } \\
\text { adhere? Are they on the } \\
\text { infrastructure, if so } \\
\text { where? }\end{array}$ & $\begin{array}{l}\text { Have seen information that ceramics and porcelain may } \\
\text { deter them from adhering. }\end{array}$ \\
\hline $\begin{array}{l}\text { Are zebra mussels } \\
\text { interfering with O\&M? If } \\
\text { so, at what cost? }\end{array}$ & $\begin{array}{l}\text { Zebra Mussels within the Gavins Point Project have resulted } \\
\text { in upwards of a } 50 \% \text { increase in the time needed to } \\
\text { complete routine maintenance tasks that involve the plants } \\
\text { cooling water systems. Asian Clams continue to create } \\
\text { issues within several power facilities (Gavins Point). The } \\
\text { impact is less severe than ZM at this time. Asian Clam } \\
\text { issues dissipate as ZM outcompetes them. These are } \\
\text { approximations based on talks with the field offices. We are } \\
\text { currently unable to support those numbers with anything } \\
\text { concrete. Omaha can only qualify but not quantify the } \\
\text { impacts }\end{array}$ \\
\hline $\begin{array}{l}\text { What methods are used } \\
\text { for mussel mitigation } \\
\text { (facility retrofit, scraping, } \\
\text { chemicals, jet washing, } \\
\text { desiccation)? }\end{array}$ & $\begin{array}{l}\text { Current plan is to use an ultrasonic device to kill the } \\
\text { mussels as they enter our raw water piping. }\end{array}$ \\
\hline $\begin{array}{l}\text { What is an estimate of } \\
\text { down time due to zebra } \\
\text { mussel mitigation? }\end{array}$ & \\
\hline $\begin{array}{l}\text { Does your district take } \\
\text { any preventative } \\
\text { measures to deter zebra } \\
\text { mussels? }\end{array}$ & \\
\hline $\begin{array}{l}\text { Please provide projects } \\
\text { impacted by zebra } \\
\text { mussels and a point of } \\
\text { contact }\end{array}$ & \\
\hline
\end{tabular}


Table A-19. Questionnaire Responses: Portland NWP District.

\begin{tabular}{|c|c|}
\hline Questions & Answers \\
\hline $\begin{array}{l}\text { Are there zebra mussels in your district? If } \\
\text { so, at which locations within the district } \\
\text { are they present? }\end{array}$ & $\begin{array}{l}\text { No current zebra mussels in entire NWD } \\
\text { known with possible exception of the one } \\
\text { dot on the USGS map in Montana }\end{array}$ \\
\hline \multicolumn{2}{|l|}{$\begin{array}{l}\text { If not, has the district ever had zebra } \\
\text { mussels (in the past but died off -may hint } \\
\text { at cyclical patterns)? }\end{array}$} \\
\hline \multicolumn{2}{|l|}{$\begin{array}{l}\text { How bad is the infestation? Estimate } \\
\text { density and abundance in the district. }\end{array}$} \\
\hline \multicolumn{2}{|l|}{$\begin{array}{l}\text { On what surfaces do they adhere? Are } \\
\text { they on the infrastructure, if so where? }\end{array}$} \\
\hline \multicolumn{2}{|l|}{$\begin{array}{l}\text { Are zebra mussels interfering with O\&M? If } \\
\text { so, at what cost? }\end{array}$} \\
\hline \multicolumn{2}{|l|}{$\begin{array}{l}\text { What methods are used for mussel } \\
\text { mitigation (facility retrofit, scraping, } \\
\text { chemicals, jet washing, desiccation)? }\end{array}$} \\
\hline \multicolumn{2}{|l|}{$\begin{array}{l}\text { What is an estimate of down time due to } \\
\text { zebra mussel mitigation? }\end{array}$} \\
\hline \multicolumn{2}{|l|}{$\begin{array}{l}\text { Does your district take any preventative } \\
\text { measures to deter zebra mussels? }\end{array}$} \\
\hline \multicolumn{2}{|l|}{$\begin{array}{l}\text { Please provide projects impacted by zebra } \\
\text { mussels and a point of contact }\end{array}$} \\
\hline Additional comments & $\begin{array}{l}\text { They are at Missouri River hydroelectric } \\
\text { (NWK, buildup needing prevented). }\end{array}$ \\
\hline Questionnaire: Walla Walla NWW District & Answers \\
\hline $\begin{array}{l}\text { Are there zebra mussels in your district? If } \\
\text { so, at which locations within the district } \\
\text { are they present? }\end{array}$ & Not yet. \\
\hline \multicolumn{2}{|l|}{$\begin{array}{l}\text { If not, has the district ever had zebra } \\
\text { mussels (in the past but died off -may hint } \\
\text { at cyclical patterns)? }\end{array}$} \\
\hline \multicolumn{2}{|l|}{$\begin{array}{l}\text { How bad is the infestation? Estimate } \\
\text { density and abundance in the district. }\end{array}$} \\
\hline \multicolumn{2}{|l|}{$\begin{array}{l}\text { On what surfaces do they adhere? Are } \\
\text { they on the infrastructure, if so where? }\end{array}$} \\
\hline \multicolumn{2}{|l|}{$\begin{array}{l}\text { Are zebra mussels interfering with } 0 \& M \text { ? If } \\
\text { so, at what cost? }\end{array}$} \\
\hline \multicolumn{2}{|l|}{$\begin{array}{l}\text { What methods are used for mussel } \\
\text { mitigation (facility retrofit, scraping, } \\
\text { chemicals, jet washing, desiccation)? }\end{array}$} \\
\hline \multicolumn{2}{|l|}{$\begin{array}{l}\text { What is an estimate of down time due to } \\
\text { zebra mussel mitigation? }\end{array}$} \\
\hline \multicolumn{2}{|l|}{$\begin{array}{l}\text { Does your district take any preventative } \\
\text { measures to deter zebra mussels? }\end{array}$} \\
\hline $\begin{array}{l}\text { Please provide projects impacted by zebra } \\
\text { mussels and a point of contact }\end{array}$ & \\
\hline
\end{tabular}




\section{A.5 South Atlantic Division}

Table A-20. Questionnaire Responses: Charleston SAC, Savannah SAS, and Wilmington SAW Districts.

\begin{tabular}{|l|l|}
\hline Questions & Answers \\
\hline $\begin{array}{l}\text { Are there zebra mussels in your district? If so, at } \\
\text { which locations within the district are they present? }\end{array}$ & No \\
\hline $\begin{array}{l}\text { If not, has the district ever had zebra mussels (in the } \\
\text { past but died off -may hint at cyclical patterns)? }\end{array}$ & \\
\hline $\begin{array}{l}\text { How bad is the infestation? Estimate density and } \\
\text { abundance in the district. }\end{array}$ & \\
\hline $\begin{array}{l}\text { On what surfaces do they adhere? Are they on the } \\
\text { infrastructure, if so where? }\end{array}$ & \\
\hline $\begin{array}{l}\text { Are zebra mussels interfering with O\&M? If so, at } \\
\text { what cost? }\end{array}$ & \\
\hline $\begin{array}{l}\text { What methods are used for mussel mitigation } \\
\text { (facility retrofit, scraping, chemicals, jet washing, } \\
\text { desiccation)? }\end{array}$ & \\
\hline $\begin{array}{l}\text { What is an estimate of down time due to zebra } \\
\text { mussel mitigation? }\end{array}$ & \\
\hline $\begin{array}{l}\text { Does your district take any preventative measures to } \\
\text { deter zebra mussels? }\end{array}$ & \\
\hline $\begin{array}{l}\text { Please provide projects impacted by zebra mussels } \\
\text { and a point of contact }\end{array}$ & \\
\hline Questionnaire: Jacksonville SAJ District & Answers \\
\hline $\begin{array}{l}\text { Are there zebra mussels in your district? If so, at } \\
\text { which locations within the district are they present? }\end{array}$ & $\begin{array}{l}\text { No knowledge of zebra mussels } \\
\text { ever being an issue on our } \\
\text { projects. }\end{array}$ \\
\hline $\begin{array}{l}\text { If not, has the district ever had zebra mussels (in the } \\
\text { past but died off -may hint at cyclical patterns)? }\end{array}$ & \\
\hline $\begin{array}{l}\text { How bad is the infestation? Estimate density and } \\
\text { abundance in the district. }\end{array}$ & \\
\hline $\begin{array}{l}\text { On what surfaces do they adhere? Are they on the } \\
\text { infrastructure, if so where? }\end{array}$ & \\
\hline $\begin{array}{l}\text { Are zebra mussels interfering with O\&M? If so, at } \\
\text { what cost? }\end{array}$ & \\
\hline $\begin{array}{l}\text { What methods are used for mussel mitigation } \\
\text { (facility retrofit, scraping, chemicals, jet washing, } \\
\text { desiccation)? } \\
\text { mussel mitigation? } \\
\text { deter zebra mussels? }\end{array}$ & \\
\hline and ant is ant & \\
\hline
\end{tabular}


Table A-21. Questionnaire Responses: Mobile SAM District.

\begin{tabular}{|l|l|}
\hline Questions & Answers \\
\hline $\begin{array}{l}\text { Are there zebra mussels in your district? If so, at which } \\
\text { locations within the district are they present? }\end{array}$ & No \\
\hline $\begin{array}{l}\text { If not, has the district ever had zebra mussels (in the past } \\
\text { but died off -may hint at cyclical patterns)? }\end{array}$ & \\
\hline $\begin{array}{l}\text { How bad is the infestation? Estimate density and } \\
\text { abundance in the district. }\end{array}$ & \\
\hline $\begin{array}{l}\text { On what surfaces do they adhere? Are they on the } \\
\text { infrastructure, if so where? }\end{array}$ & \\
\hline $\begin{array}{l}\text { Are zebra mussels interfering with O\&M? If so, at what } \\
\text { cost? }\end{array}$ & \\
\hline $\begin{array}{l}\text { What methods are used for mussel mitigation (facility } \\
\text { retrofit, scraping, chemicals, jet washing, desiccation)? }\end{array}$ & \\
\hline $\begin{array}{l}\text { What is an estimate of down time due to zebra mussel } \\
\text { mitigation? }\end{array}$ & \\
\hline $\begin{array}{l}\text { Does your district take any preventative measures to deter } \\
\text { zebra mussels? }\end{array}$ & We do not have any \\
\hline $\begin{array}{l}\text { Please provide projects impacted by zebra mussels and a } \\
\text { point of contact }\end{array}$ & \\
\hline
\end{tabular}




\section{A.6 South Pacific Division*}

Table A-22. Questionnaire Responses: Albuquerque SPA Division.

\begin{tabular}{|l|l|}
\hline Questions & Answers \\
\hline $\begin{array}{l}\text { Are there zebra mussels in } \\
\text { your district? If so, at } \\
\text { which locations within the } \\
\text { district are they present? }\end{array}$ & Not to date. \\
\hline $\begin{array}{l}\text { If not, has the district ever } \\
\text { had zebra mussels (in the } \\
\text { past but died off -may hint } \\
\text { at cyclical patterns)? }\end{array}$ & $\begin{array}{l}\text { There was one USGS zebra mussel hit on the Arkansas } \\
\text { River back around 2010 near Pueblo. It was found on a } \\
\text { boat and they (state parks and wildlife) now have a } \\
\text { vigorous program to check boats. That was the only hit and } \\
\text { there hasn't been one since. }\end{array}$ \\
\hline $\begin{array}{l}\text { How bad is the } \\
\text { infestation? Estimate } \\
\text { density and abundance in } \\
\text { the district. }\end{array}$ & \\
\hline $\begin{array}{l}\text { On what surfaces do they } \\
\text { adhere? Are they on the } \\
\text { infrastructure, if so } \\
\text { where? }\end{array}$ & \\
\hline $\begin{array}{l}\text { Are zebra mussels } \\
\text { interfering with O\&M? If } \\
\text { so, at what cost? }\end{array}$ & \\
\hline $\begin{array}{l}\text { What methods are used } \\
\text { for mussel mitigation } \\
\text { (facility retrofit, scraping, } \\
\text { chemicals, jet washing, } \\
\text { desiccation)? }\end{array}$ & \\
\hline $\begin{array}{l}\text { What is an estimate of } \\
\text { down time due to zebra } \\
\text { mussel mitigation? }\end{array}$ & \\
\hline $\begin{array}{l}\text { Does your district take any } \\
\text { preventative measures to } \\
\text { deter zebra mussels? }\end{array}$ & $\begin{array}{l}\text { Yes, and constantly funding these monitoring activities is } \\
\text { an issue. Have an early detection program with water } \\
\text { sampling and analysis for veligers. Monitor 6 projects - } \\
\text { John Martin Dam (CO), Trindad Dam (CO), Santa Rosa Dam, } \\
\text { Abiquiu Dam (NM), and Cochiti Dm (NM) by sampling } \\
\text { plankton between June and September. Also some boat } \\
\text { inspections are done by NM and CO State Parks. }\end{array}$ \\
\hline $\begin{array}{l}\text { Please provide projects } \\
\text { mussels and a point of } \\
\text { contact }\end{array}$ & \\
\hline
\end{tabular}

* Note that there were Limited responses from Los Angeles SPK and San Francisco SPN Districts. 
Table A-23. Questionnaire Responses: Los Angeles SPL District.

\begin{tabular}{|l|l|}
\hline Questions & Answers \\
\hline $\begin{array}{l}\text { Are there zebra mussels in } \\
\text { your district? If so, at which } \\
\text { locations within the district } \\
\text { are they present? }\end{array}$ & $\begin{array}{l}\text { No. None in any USACE lakes in California. We do not } \\
\text { have any zebra/quagga mussel at any of our district } \\
\text { projects. We do not hold permanent pools at any of our } \\
\text { projects except for Alamo Dam in Arizona and I confirmed } \\
\text { with the Park Manager there that they do not have any } \\
\text { zebra/quagga mussel issues. }\end{array}$ \\
\hline $\begin{array}{l}\text { If not, has the district ever } \\
\text { had zebra mussels (in the } \\
\text { past but died off -may hint } \\
\text { at cyclical patterns)? }\end{array}$ & \\
\hline $\begin{array}{l}\text { How bad is the infestation? } \\
\text { Estimate density and } \\
\text { abundance in the district. }\end{array}$ & \\
\hline $\begin{array}{l}\text { On what surfaces do they } \\
\text { adhere? Are they on the } \\
\text { infrastructure, if so where? }\end{array}$ & \\
\hline $\begin{array}{l}\text { Are zebra mussels } \\
\text { interfering with O\&M? If so, } \\
\text { at what cost? }\end{array}$ & \\
\hline $\begin{array}{l}\text { What methods are used for } \\
\text { mussel mitigation (facility } \\
\text { retrofit, scraping, chemicals, } \\
\text { jet washing, desiccation)? }\end{array}$ & \\
\hline $\begin{array}{l}\text { What is an estimate of down } \\
\text { time due to zebra mussel } \\
\text { mitigation? }\end{array}$ & \\
\hline $\begin{array}{l}\text { Does your district take any } \\
\text { preventative measures to } \\
\text { deter zebra mussels? }\end{array}$ & \\
\hline $\begin{array}{l}\text { Please provide projects } \\
\text { impacted by zebra mussels } \\
\text { and a point of contact }\end{array}$ \\
\hline
\end{tabular}


Table A-24. Questionnaire Responses: Sacramento SPK District.

\begin{tabular}{|l|l|}
\hline Questions & Answers \\
\hline $\begin{array}{l}\text { Are there zebra mussels in your district? If so, at } \\
\text { which locations within the district are they } \\
\text { present? }\end{array}$ & $\begin{array}{l}\text { No. None in any USACE lakes in } \\
\text { California }\end{array}$ \\
\hline $\begin{array}{l}\text { If not, has the district ever had zebra mussels (in } \\
\text { the past but died off -may hint at cyclical } \\
\text { patterns)? }\end{array}$ & No \\
\hline $\begin{array}{l}\text { How bad is the infestation? Estimate density and } \\
\text { abundance in the district. }\end{array}$ & NA \\
\hline $\begin{array}{l}\text { On what surfaces do they adhere? Are they on the } \\
\text { infrastructure, if so where? }\end{array}$ & NA \\
\hline $\begin{array}{l}\text { Are zebra mussels interfering with O\&M? If so, at } \\
\text { what cost? }\end{array}$ & No \\
\hline $\begin{array}{l}\text { What methods are used for mussel mitigation } \\
\text { (facility retrofit, scraping, chemicals, jet washing, } \\
\text { desiccation)? }\end{array}$ & NA \\
\hline $\begin{array}{l}\text { What is an estimate of down time due to zebra } \\
\text { mussel mitigation? }\end{array}$ & NA \\
\hline $\begin{array}{l}\text { Does your district take any preventative measures } \\
\text { to deter zebra mussels? }\end{array}$ & $\begin{array}{l}\text { Yes - monthly substrate monitoring, } \\
\text { posted bulletins, partnership with } \\
\text { CDFW }\end{array}$ \\
\hline $\begin{array}{l}\text { Please provide projects impacted by zebra } \\
\text { mussels and a point of contact }\end{array}$ & NA \\
\hline
\end{tabular}

Table A-25. Questionnaire Responses: San Francisco SPN District.

\begin{tabular}{|l|l|}
\hline Question & Answers \\
\hline $\begin{array}{l}\text { Are there zebra mussels in your district? If so, at which locations within the } \\
\text { district are they present? }\end{array}$ & \\
\hline $\begin{array}{l}\text { If not, has the district ever had zebra mussels (in the past but died off -may } \\
\text { hint at cyclical patterns)? }\end{array}$ & \\
\hline How bad is the infestation? Estimate density and abundance in the district. & \\
\hline On what surfaces do they adhere? Are they on the infrastructure, if so where? & \\
\hline Are zebra mussels interfering with O\&M? If so, at what cost? & \\
\hline $\begin{array}{l}\text { What methods are used for mussel mitigation (facility retrofit, scraping, } \\
\text { chemicals, jet washing, desiccation)? }\end{array}$ & \\
\hline What is an estimate of down time due to zebra mussel mitigation? & \\
\hline Does your district take any preventative measures to deter zebra mussels? & \\
\hline Please provide projects impacted by zebra mussels and a point of contact & \\
\hline
\end{tabular}




\section{A.7 Southwestern District*}

Table A-26. Questionnaire Responses: Fort Worth SWF District.

\begin{tabular}{|c|c|}
\hline Questions & Answers \\
\hline $\begin{array}{l}\text { Are there zebra } \\
\text { mussels in your } \\
\text { district? If so, } \\
\text { at which } \\
\text { locations within } \\
\text { the district are } \\
\text { they present? }\end{array}$ & Yes, in five lakes but none in the lakes with hydroelectric structures. \\
\hline $\begin{array}{l}\text { If not, has the } \\
\text { district ever } \\
\text { had zebra } \\
\text { mussels (in the } \\
\text { past but died } \\
\text { off -may hint at } \\
\text { cyclical } \\
\text { patterns)? }\end{array}$ & $\begin{array}{l}\text { The environment in Texas is hot and the water levels fluctuate a lot } \\
\text { which makes it tough for the zebras to flourish. There are good years } \\
\text { and bad. In general it was observed after introduction the zebras } \\
\text { flourish then the population collapses once they eat themselves out of } \\
\text { food and then will slowly rebound and level off at a manageable level. } \\
\text { One year the flooding was so bad they adhered to picnic tables and } \\
\text { buildings in flood zones and then when the water receded they were } \\
\text { hung out to dry - decimating one generation of mussels. }\end{array}$ \\
\hline $\begin{array}{l}\text { How bad is the } \\
\text { infestation? } \\
\text { Estimate } \\
\text { density and } \\
\text { abundance in } \\
\text { the district. }\end{array}$ & \\
\hline $\begin{array}{l}\text { On what } \\
\text { surfaces do } \\
\text { they adhere? } \\
\text { Are they on the } \\
\text { infrastructure, } \\
\text { if so where? }\end{array}$ & Gates, concrete surfaces. \\
\hline $\begin{array}{l}\text { Are zebra } \\
\text { mussels } \\
\text { interfering with } \\
\text { O\&M? If so, at } \\
\text { what cost? }\end{array}$ & \\
\hline $\begin{array}{l}\text { What methods } \\
\text { are used for } \\
\text { mussel } \\
\text { mitigation } \\
\text { (facility retrofit, } \\
\text { scraping, } \\
\text { chemicals, jet } \\
\text { washing, } \\
\text { desiccation)? }\end{array}$ & $\begin{array}{l}\text { They have scraped off in past but put coatings on } 4 \text { to } 5 \text { years ago and } \\
\text { are now researching new coatings to redo. Original product was a } \\
\text { Sherman Williams product. Coatings don't work very well on some } \\
\text { concrete surfaces such as wet wells because they can't really get } \\
\text { them dry and zebra mussels are crafty that they will adhere to any } \\
\text { crack or place where the coating is flawed }\end{array}$ \\
\hline
\end{tabular}

\footnotetext{
* Note that Tulsa SWT District provided a 2012 document on impacts of Zebra Mussels to hydropower plants and gave another contact; also note that the Pacific Ocean Division reported no zebra nor quagga mussels.
} 


\begin{tabular}{|l|l|}
\hline Questions & Answers \\
\hline $\begin{array}{l}\text { What is an } \\
\text { estimate of } \\
\text { down time due } \\
\text { to zebra } \\
\text { mussel } \\
\text { mitigation? }\end{array}$ & \\
\hline $\begin{array}{l}\text { Does your } \\
\text { district take } \\
\text { any } \\
\text { preventative } \\
\text { measures to } \\
\text { deter zebra } \\
\text { mussels? }\end{array}$ & $\begin{array}{l}\text { Early detection program with the state, academia and USGS. Worry } \\
\text { about infestation in Sam Rayburn Reservoir because of water } \\
\text { chemistry. They have a lot of water transfer between lakes so if one } \\
\text { lake infed there is a good chance another will be too. They work } \\
\text { with the to minimize chances through careful water }\end{array}$ \\
\hline $\begin{array}{l}\text { Please provide } \\
\text { projects } \\
\text { impacted by } \\
\text { zebra mussels } \\
\text { and a point of } \\
\text { contact }\end{array}$ & $\begin{array}{l}\text { Study conducted by Bureau of Rec from 2014: } \\
\text { https://www.swf.usace.army.mil/Portals/47/docs/Environmental } \\
\text { /Water/Zebra_Mussel_Resource_Document_FINAL.pdf }\end{array}$ \\
\hline
\end{tabular}

Table A-27. Questionnaire Responses: Galveston SWG District.

\begin{tabular}{|l|l|}
\hline Questions & Answers \\
\hline $\begin{array}{l}\text { Are there zebra mussels in your } \\
\text { district? If so, at which locations } \\
\text { within the district are they present? }\end{array}$ & $\begin{array}{l}\text { I have not heard of zebra mussels being } \\
\text { discovered in the Galveston District's AOR. } \\
\text { Probably Lake Livingston is the furthest south } \\
\text { and it is not a Corps lake. }\end{array}$ \\
\hline $\begin{array}{l}\text { If not, has the district ever had zebra } \\
\text { mussels (in the past but died off - } \\
\text { may hint at cyclical patterns)? }\end{array}$ & \\
\hline $\begin{array}{l}\text { How bad is the infestation? Estimate } \\
\text { density and abundance in the } \\
\text { district. }\end{array}$ & \\
\hline $\begin{array}{l}\text { On what surfaces do they adhere? } \\
\text { Are they on the infrastructure, if so } \\
\text { where? }\end{array}$ & \\
\hline $\begin{array}{l}\text { Are zebra mussels interfering with } \\
\text { O\&M? If so, at what cost? }\end{array}$ & $\begin{array}{l}\text { Galveston has not had any infrastructure } \\
\text { impacts from zebra or quagga mussels as of yet } \\
\text { that I am aware of }\end{array}$ \\
\hline $\begin{array}{l}\text { What methods are used for mussel } \\
\text { mitigation (facility retrofit, scraping, } \\
\text { chemicals, jet washing, desiccation)? }\end{array}$ & \\
\hline $\begin{array}{l}\text { What is an estimate of down time } \\
\text { due to zebra mussel mitigation? }\end{array}$ & \\
\hline $\begin{array}{l}\text { Does your district take any } \\
\text { preventative measures to deter zebra } \\
\text { mussels? }\end{array}$ & \\
\hline $\begin{array}{l}\text { Please provide projects impacted by } \\
\text { zebra mussels and a point of contact }\end{array}$ & \\
\hline
\end{tabular}


Table A-28. Questionnaire Responses: Little Rock SWL District.

\begin{tabular}{|c|c|}
\hline Questions & Answers \\
\hline $\begin{array}{l}\text { Are there zebra mussels in } \\
\text { your district? If so, at which } \\
\text { locations within the district } \\
\text { are they present? }\end{array}$ & $\begin{array}{l}\text { Yes there are mussels on Bullshoals Lake and as of } 31 \\
\text { Aug 2018, the White River tail waters and in the } \\
\text { MKARNS navigation system on the Arkansas River. }\end{array}$ \\
\hline $\begin{array}{l}\text { If not, has the district ever } \\
\text { had zebra mussels (in the } \\
\text { past but died off -may hint at } \\
\text { cyclical patterns)? }\end{array}$ & $\mathrm{N} / \mathrm{A}$ \\
\hline $\begin{array}{l}\text { How bad is the infestation? } \\
\text { Estimate density and } \\
\text { abundance in the district. }\end{array}$ & $\begin{array}{l}\text { Bull Shoals - They were first discovered in BSL in the } \\
\text { upper parts in } 2007 \text {. Each year after they spread to all } \\
\text { other areas of the lake with highest concentrations in } \\
2013 \text {. Although still present, they have since appeared to } \\
\text { have lessened in density and abundance over the last } 5 \\
\text { years. } \\
\text { White River BS Tail Waters - Verified present in } 2017 \text { - } \\
\text { At present they are found in very low density with the } \\
\text { number of zebra mussels appearing to be highest } \\
\text { directly below the dam, but have already been found up } \\
\text { to } 8 \text { miles below the dam. }\end{array}$ \\
\hline $\begin{array}{l}\text { On what surfaces do they } \\
\text { adhere? Are they on the } \\
\text { infrastructure, if so where? }\end{array}$ & $\begin{array}{l}\text { They are found on all surfaces below the water surface } \\
\text { down to around } 35 \text { feet on the lake side of Bull Shoals } \\
\text { Dam. Most concerning are the ones adhering to intake } \\
\text { openings and pipes which could in time cause water } \\
\text { inflow restrictions and even blockage. }\end{array}$ \\
\hline $\begin{array}{l}\text { Are zebra mussels } \\
\text { interfering with } 0 \& M \text { ? If so, } \\
\text { at what cost? }\end{array}$ & $\begin{array}{l}\text { At present they have not, however, at some point in the } \\
\text { future, these may require manual removal or chemical } \\
\text { treatment which could be quite costly. }\end{array}$ \\
\hline $\begin{array}{l}\text { What methods are used for } \\
\text { mussel mitigation (facility } \\
\text { retrofit, scraping, chemicals, } \\
\text { jet washing, desiccation)? }\end{array}$ & $\begin{array}{l}\text { None at present, other than scraping them off of areas } \\
\text { above the normal water line left behind after a high } \\
\text { water event. }\end{array}$ \\
\hline $\begin{array}{l}\text { What is an estimate of down } \\
\text { time due to zebra mussel } \\
\text { mitigation? }\end{array}$ & None at present. \\
\hline $\begin{array}{l}\text { Does your district take any } \\
\text { preventative measures to } \\
\text { deter zebra mussels? }\end{array}$ & None at BSL. \\
\hline $\begin{array}{l}\text { Please provide projects } \\
\text { impacted by zebra mussels } \\
\text { and a point of contact }\end{array}$ & $\begin{array}{l}\text {-Cherrie-Lee Phillip, Little Rock District Conservation } \\
\text { Biologist } \\
\text {-Bull Shoals Lake and White River Bull Shoals Tail } \\
\text { Waters: Bruce Caldwell, Natural Resources Chief, } \\
\text { Mountain Home Project Office } \\
\text {-Jeremy Risley, District } 2 \text { Fisheries Supervisor, Arkansas } \\
\text { Game and Fish Commission } \\
\text {-Christy Graham, Trout Management Program Supervisor, } \\
\text { Arkansas Game and Fish Commission } \\
\text {-Jimmy Barnett (He can answer questions on densities) } \\
\text { Aquatic Nuisance Species Coordinator, Arkansas Game \& } \\
\text { Fish (AGFC) }\end{array}$ \\
\hline
\end{tabular}


Table A-29. Questionnaire Responses: Tulsa SWT District.

\begin{tabular}{|c|c|}
\hline Questions & Answers (taken from 2012 document) \\
\hline $\begin{array}{l}\text { Are there zebra mussels } \\
\text { in your district? If so, at } \\
\text { which locations within the } \\
\text { district are they present? }\end{array}$ & $\begin{array}{l}\text { Yes, list of six multipurpose projects that include hydropower } \\
\text { that have zebra mussels: } \\
\text { Ft. Gibson, Keystone Lake, Eufaula, RS Kerr, Webbers Falls, } \\
\text { Denison Dam. Other lakes w/ZM include: Kaw, Ooloagah, } \\
\text { Skiatook, Chouteau, Newt Graham, WD Mayo, Texoma, } \\
\text { Council Grove, El Dorado Reservoir, John Redmond } \\
\text { Reservoir, Marion. }\end{array}$ \\
\hline $\begin{array}{l}\text { If not, has the district } \\
\text { ever had zebra mussels } \\
\text { (in the past but died off - } \\
\text { may hint at cyclical } \\
\text { patterns)? }\end{array}$ & \\
\hline $\begin{array}{l}\text { How bad is the } \\
\text { infestation? Estimate } \\
\text { density and abundance } \\
\text { in the district. }\end{array}$ & \\
\hline $\begin{array}{l}\text { On what surfaces do they } \\
\text { adhere? Are they on the } \\
\text { infrastructure, if so } \\
\text { where? }\end{array}$ & \\
\hline $\begin{array}{l}\text { Are zebra mussels } \\
\text { interfering with O\&M? If } \\
\text { so, at what cost? }\end{array}$ & $\begin{array}{l}\text { Operation and maintenance impacts to each hydropower } \\
\text { facility in the Tulsa District varies and is dependent on the } \\
\text { stage of zebra mussel invasion, the type of strainers that } \\
\text { are used, and the design of the powerhouse. The design of } \\
\text { three powerhouses (Eufaula, R.S. Kerr, and Denison) } \\
\text { includes a deluge system for the facility's transformer fire } \\
\text { suppression, which can be impacted by zebra mussels. In } \\
2012 \text {, Ft. Gibson reported an increase in O\&M by } 10 \text { work } \\
\text { hours to deal with the impacts of zebra mussels on the A/C } \\
\text { system. At Eufaula in } 2010 \text {, it took } 10 \text { work hours ( } \$ 905.00 \text { ) } \\
\text { to clean clogged cooling water intake strainers and } 48 \text { work } \\
\text { hours ( } \$ 4,344.00 \text { ) to clean the main unit head gates. In } \\
2011 \text {, it took } 10.5 \text { work hours ( } \$ 950.00 \text { ) to clean the } \\
\text { cooling water intake strainers and } 4 \text { work hours ( } \$ 362.00 \text { ) } \\
\text { to clean the transformer fire suppression equipment. In } \\
2012,7 \text { work hours ( } \$ 724.00 \text { ) were spent cleaning the } \\
\text { cooling water intake strainers and } 8 \text { work hours were spent } \\
\text { on cleaning the transformer fire suppression equipment. } \\
\text { During the fire suppression tests ( } 2012), \text { zebra mussels } \\
\text { impacted the function of the system by clogging the pump } \\
\text { and the process had to be stopped, the pump filter/strainer } \\
\text { cleaned, and the process restarted. This interruption } \\
\text { occurred several times and had there been an actual need } \\
\text { for the fire suppression, there may have been complications } \\
\text { attributed to zebra mussels fouling the effectiveness of the } \\
\text { fire suppression process and unknown extra costs } \\
\text { associated as a result. }\end{array}$ \\
\hline
\end{tabular}




\begin{tabular}{|l|l|}
\hline Questions & Answers (taken from 2012 document) \\
\hline $\begin{array}{l}\text { What methods are used } \\
\text { for mussel mitigation } \\
\text { facility retrofit, scraping, } \\
\text { chemicals, jet washing, } \\
\text { desiccation)? }\end{array}$ & $\begin{array}{l}\text { Chlorine tablets/injectors have not been used in any of the } \\
\text { hydropower plants for zebra mussel control. }\end{array}$ \\
\hline $\begin{array}{l}\text { What is an estimate of } \\
\text { down time due to zebra } \\
\text { mussel mitigation? }\end{array}$ & \\
\hline $\begin{array}{l}\text { Does your district take } \\
\text { any preventative } \\
\text { measures to deter zebra } \\
\text { mussels? }\end{array}$ & \\
\hline $\begin{array}{l}\text { Please provide projects } \\
\text { impacted by zebra } \\
\text { mussels and a point of } \\
\text { contact }\end{array}$ & $\begin{array}{l}\text { 2012 document, "Zebra Mussel Impacts to SWT } \\
\text { Bydropower Facilities", was provided by Tonya Dunn, }\end{array}$ \\
\hline
\end{tabular}




\section{Appendix B: Questionnaire Images}

This appendix included zebra mussel images gathered during the questionnaire process from various Districts.

Figure B-1. ZM on concrete in lock chamber of \#3 Lock \& Dam on Red River, April 2017, Vicksburg District.

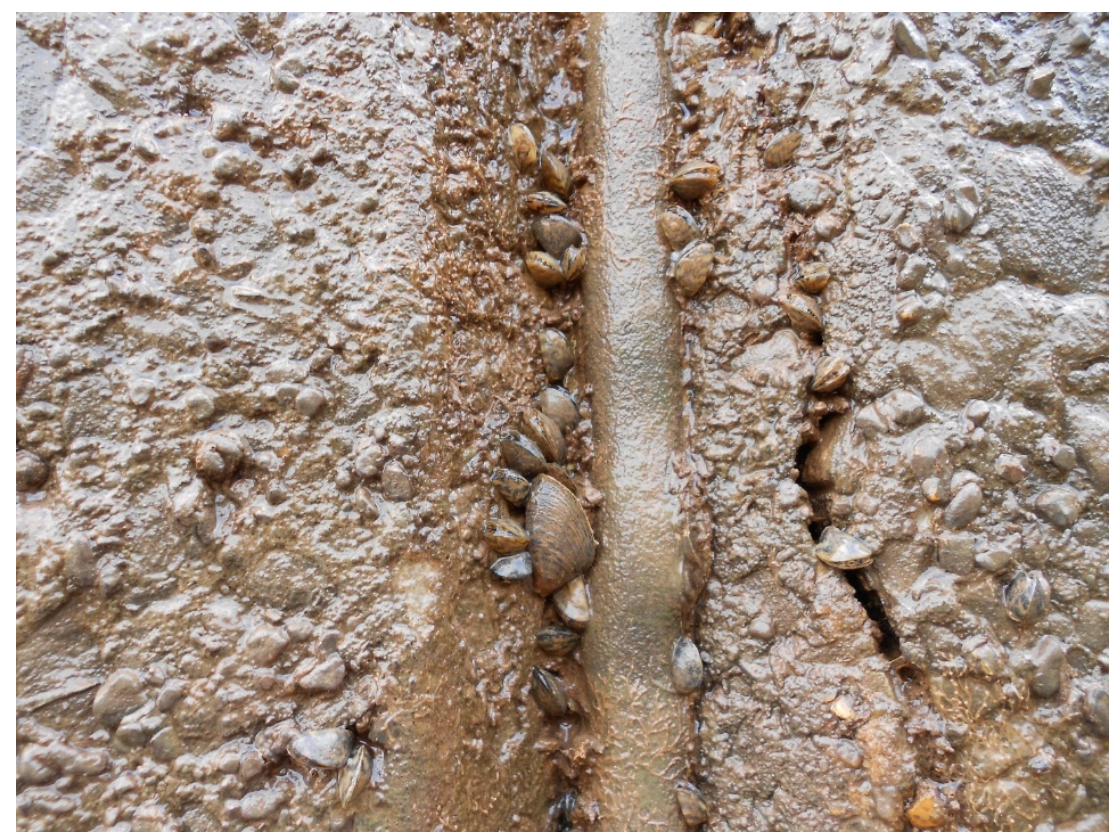

Figure B-2. ZM on concrete wall in lock chamber of \#3 Lock \& Dam on Red River, April 2017, Vicksburg District.

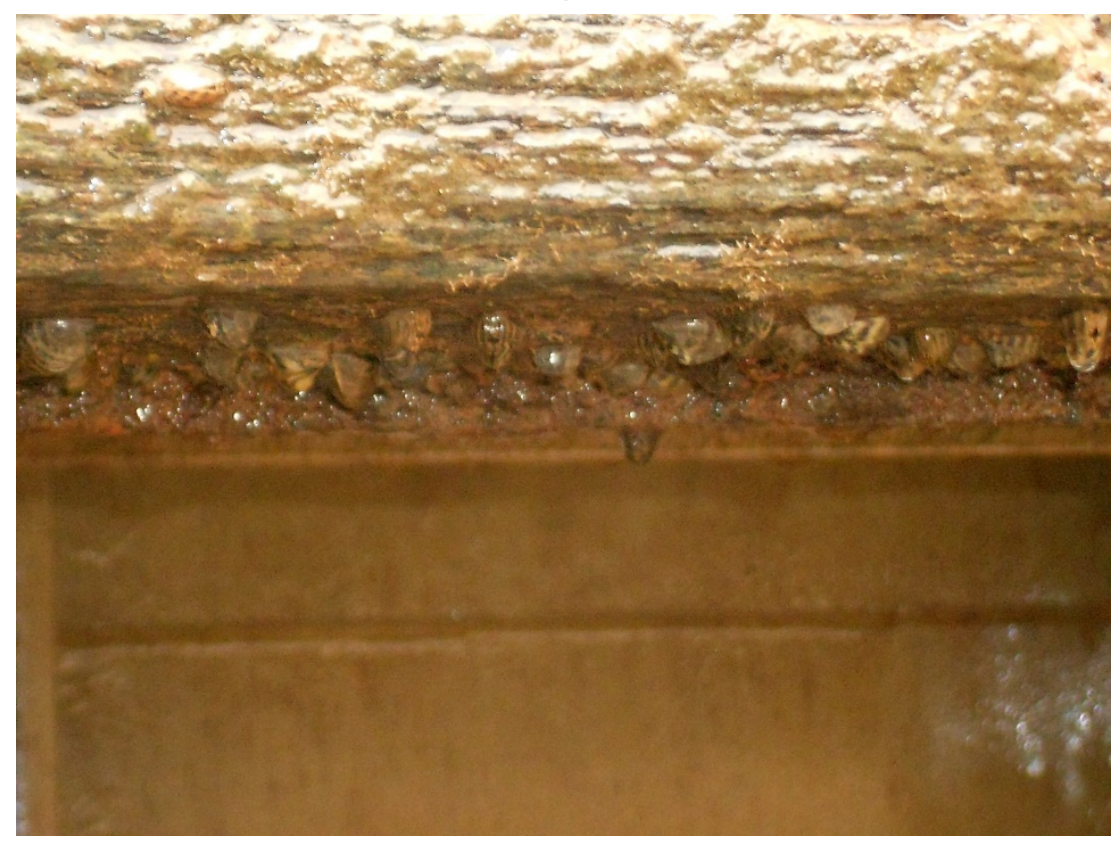


Figure B-3. ZM attached to ACM (articulated concrete mat), September 2012, Memphis District.

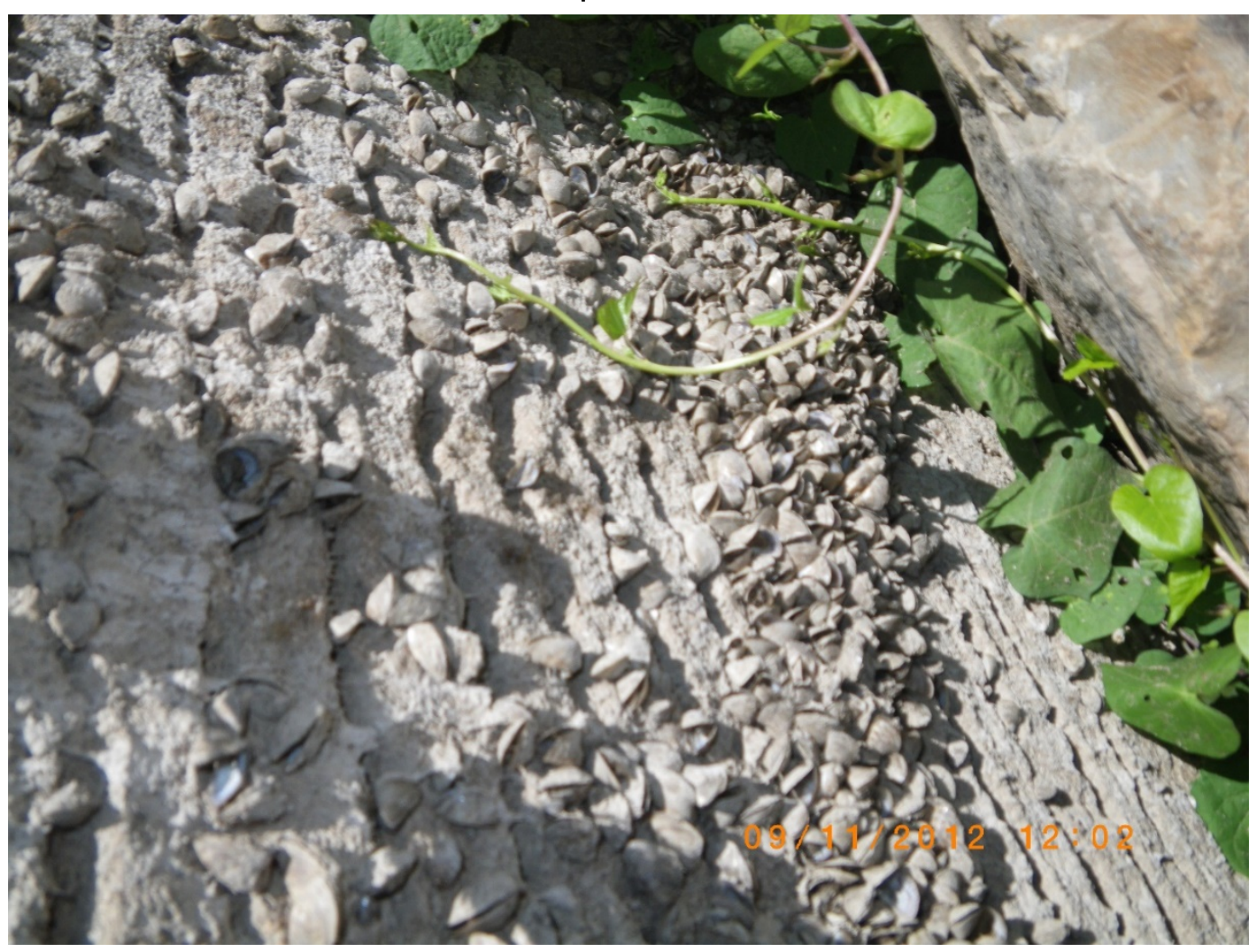

Figure B-4. Inspection gallery - Lake side of the dam after flood waters receded in 2015, Little Rock District.

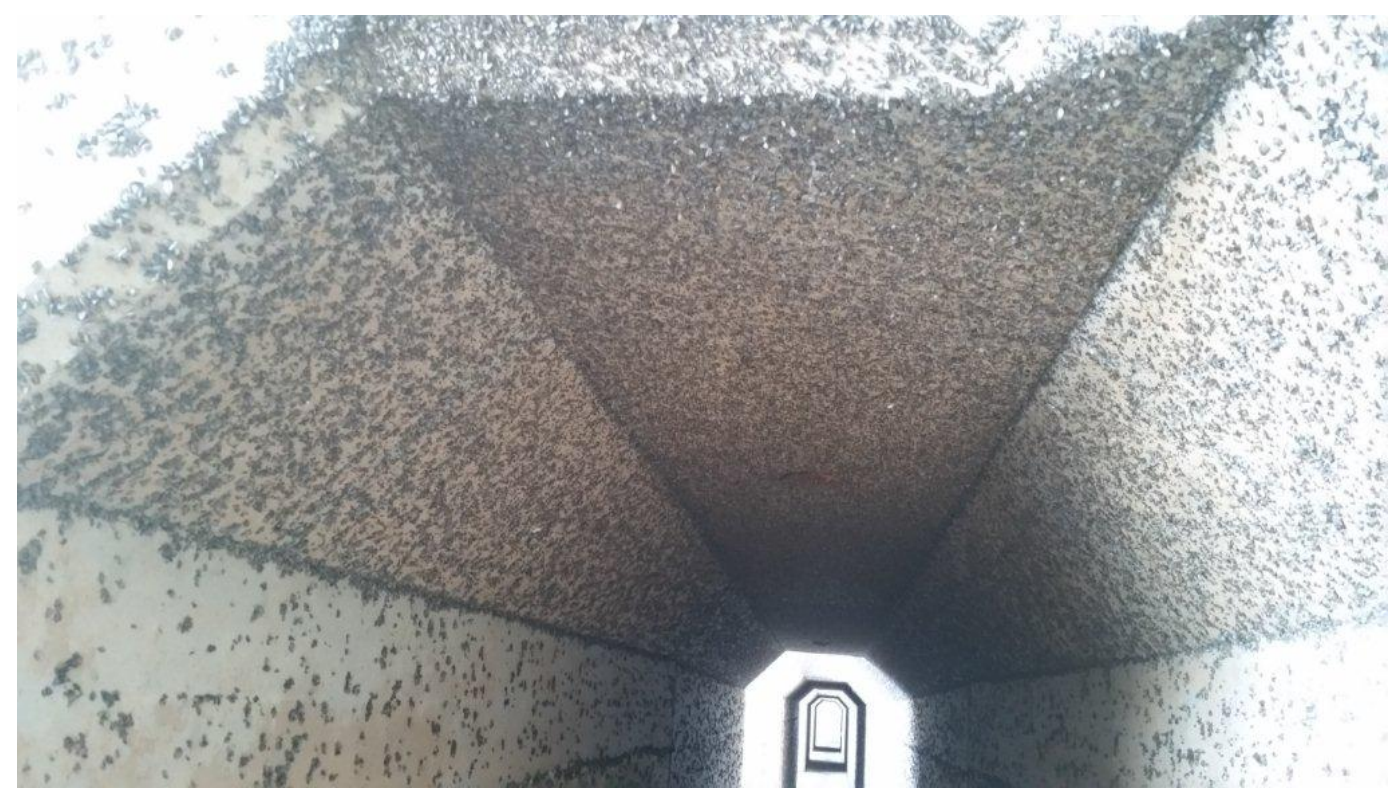


Figure B-5. Lead Hill Park boat ramp 2015, Little Rock District.

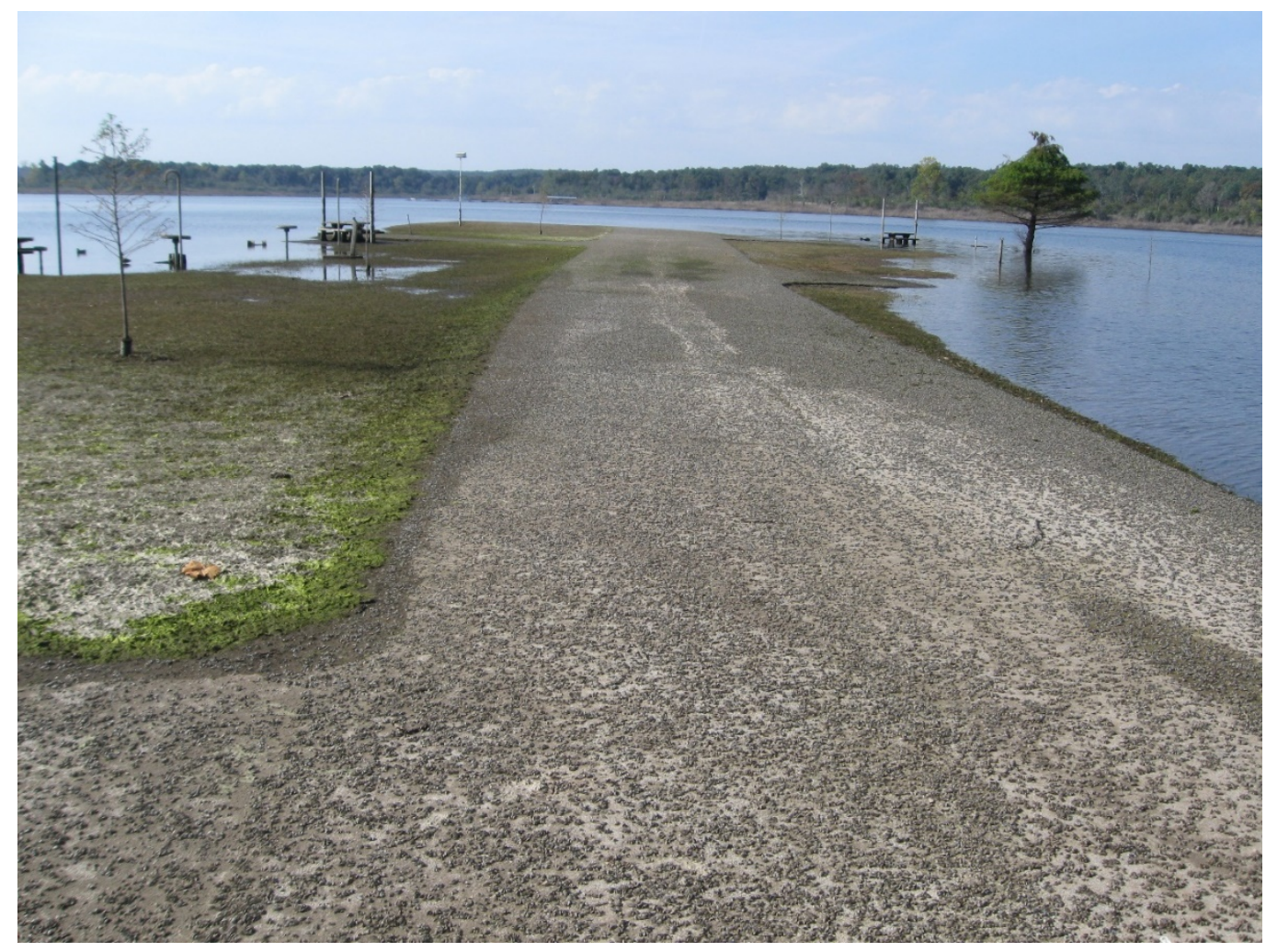




\section{Appendix C: Invasive Species Leadership Team Document}

The following content was drawn from and unpublished Invasive Species Leadership Team (ISLT) document, drafted in 2018 and titled HQ USACE NISC Response.

1 The U.S. Army Corps of Engineers manages significant infrastructure related to power, water, and transportation. The USACE manages water based transportation for both commercial and recreational purposes across the country. The Corps manages inland navigation and the lock and dam systems that facilitate this system. The Corps also manages navigation and federal channels in conjunction with coastal ports to facility international shipping and transportation. The Corps navigation program crosses between water and transportation in respect to the inquiry. In addition the Corps is the largest federal producer of hydropower. The Corps is also charged with our flood risk management program, which has significant resources related to directing, managing, and storing water to prevent flooding. For the Corps to manage navigation, hydropower, and flood risk management the agency needs manpower and facilities; the agency has an extensive building system both directly and indirectly related to its missions.

2 In general the Corps infrastructure is impacted in both direct and indirect manners from invasive species. An example of a direct impact would be the water hyacinths clogging a flood control structure due to rapid growth followed by rising waters and structure failure or flooding based on the inability to move water through the structure. While water hyacinth is a challenge to the Southern U.S. primarily, other floating and emergent invasive plants cause similar impacts and challenges throughout the country. An example of an indirect impact is Napier grass out competing the established turf on a levee system; as more and more Napier establishes vehicles have difficult traversing the levee; more rutting occurs from vehicles and the growth pattern of Napier grass allows for channeling and rutting to occur during heavy rainfall. Eventually the system needs physical repairs in addition to the re-establishment of acceptable turf.

2.1 The Corps' infrastructure is impacted in a variety of manners, but in general the concern is long-term buildup of invasive species and impacts moving to lost time, capacity, capability, or a combination of all three. All of these losses equate to expenditure impacts to control the species and remediate the impacts. A specific example related to lost time impacts 
in navigation was provided on the current challenges with water hyacinth infestations on the White River. Another example is reduce capacity for hydropower generation and increased down time because of zebra mussel infestations at Gavins Point Dam.

2.2 Broadly the Corps estimates the costs related to these impacts to be around $\$ 80$ million annually. The Invasive Species Leadership Team (ISLT) reports these impacts annually to NISC for the cross cut budget. The agency also recognizes that our estimating process is dated and plans to review and update one business practice annually to ensure we are providing accurate numbers.

2.3 In general the Corps has not completed any type of wholesale assessment; normally, work is done on a case by case basis and in response to an immediate impact or need. With the continued limitations on Operations and Maintenance (O\&M) preventative measures as suggested have not been the norm. In relation to zebra and quagga mussel infestations some efforts for preventative measures and changes in business practices have been instituted; our agency in conjunction with Bureau of Reclamation and Depart of Energy continue to research for treatment technologies and coatings to improve our capability to manage mussels and prevent establishment. Additionally, we have modified intake structures for water supply and hydropower at some locations based on understanding of when, where, and how these invasive mussels attach. The Fort Worth District has worked to minimize the possibility of spread through the water supply program. Other examples exist of similar efforts, but in general given constraints on budgets our agency has to react versus prevent.

2.4 See 2.3.

3 In reference to secondary impacts please see example from 2.1; the Corps has invasive species challenges that have primary and secondary or direct and indirect impacts. In the Southeast U.S. increase risk of wild fire and hotter fires are secondary impact from Cogongrass infestations that eliminate biodiversity from understory of pines or open grasslands. Arundo donax is causing similar challenges in California, and the Southwest U.S.

3.1 Invasive species such feral hogs and iguanas both are seen to have detrimental impacts to the environment, but both cause significant impacts to infrastructure through rooting and burrowing. Feral hog rooting on levees causes direct impacts to the structural integrity of the levees, negative impacts to 
the turf designed to protect the levee surface, and often spreads invasive seeds into the turf through manure.

4 The Corps conducts the vast majority of invasive species management activities as part of the Operations and Maintenance program; the management of invasive species as part of project operations is basic authority. The Corps does have some specific programs such as Removal of Aquatic Growth (RAG), and the Aquatic Plant Control Program; these authority are specific authorities within the Rivers and Harbors Act to address invasive plant issues related to navigation and flood risk management.

4.1 Within the Corps the Invasive Species Leadership Team (ISLT) provides support to field and recommendations to leadership on the management of invasive species. The ISLT follows a Program Management Plan that uses both executive order and federal law along with internal regulations and guidance to set priorities for the agency. Within the PgMP an annual work plan is developed to guide activities. In addition the ISLT sets research priorities for Aquatic Plant Control Research Program and the Aquatic Nuisance Species Research Program.

5 In general, the Corps has projects at every aspect of the scale. The agency has areas or projects that are conducted baseline surveys and annual monitoring for new species to projects that are completing reactionary to immediate problems. The ISLT promotes EDRR and is looking for ways to incentivize EDRR efforts; outside of this most activities are driven at a local level leaving the Corps with the entire spectrum. Invasive species activities are prioritized in the budget process along with all other project needs; a separate funding stream is not available, so invasive species projects are competing with other activities for funding and ranked out in the budget process annually.

6 Overall, the gap for supporting or improving invasive species management activities related to infrastructure or otherwise is dollars. The Corps has significant backlogged maintenance activities of all types and funding is limited.

7 If the Corps or other agencies have a consistent and adequate funding streams all the other challenges can be addressed over time through prioritization of capital. An aspect of invasive species management that is difficult to address especially in the Corps budget is consistency. If a project or district can annually maintain a level of funding to support invasive species activities success is more likely than getting large pots of money inconsistently.

8 A mission of the ISLT is to continue to refine the Corps invasive species expenditure data and report to NISC as part of the cross cut budget ex- 
ercise. The ISLT will begin a review of formula for each business practice to ensure we still reporting accurate numbers. In addition within the pie chart we assume that the Navigation, Hydropower, and Water Supply numbers are direct or indirect impacts to infrastructure. Currently, the ISLT reports the following: https://corpslakes.erdc.dren.mil/employees/invasive/pdfs/USACE\%20F13-16\%20Invasive\%20Species\%20Cost\%20Estimates.pdf

8.1 The Corps does not have a mechanism at this time to report detailed budget numbers; the ISLT developed formulas based on reviewing budgets and budget packages, work load execution, and interviewing project managers related to each business line.

8.2 The Corps does not break out these costs or impact in any manner.

9 Damien Walter, Jon Lane, and Jeremy Crossland 


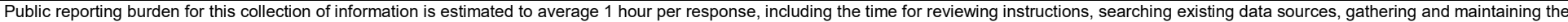

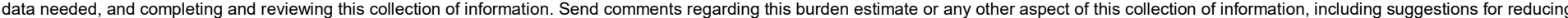

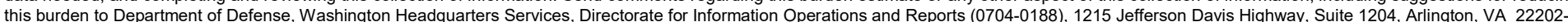

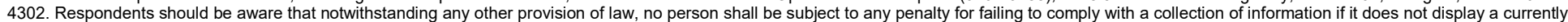
valid OMB control number. PLEASE DO NOT RETURN YOUR FORM TO THE ABOVE ADDRESS
1. REPORT DATE (DD-MM-YYYY) $01 / 01 / 2020$
Final Technical Report (TR)

\section{TITLE AND SUBTITLE}

Incidence of Zebra Mussel on U.S. Army Corps of Engineers Structures

\section{AUTHOR(S)}

K. James Hay, Irene E. MacAllister, Rebekah C. Wilson, and Abigail M. Brake
3. DATES COVERED (From - To)

5a. CONTRACT NUMBER

5b. GRANT NUMBER

5c. PROGRAM ELEMENT

96 × 3123; AMSCO 008284

5d. PROJECT NUMBER

468901

5e. TASK NUMBER

5f. WORK UNIT NUMBER

8. PERFORMING ORGANIZATION REPORT NUMBER

ERDC/CERL TR-20-2

Construction Engineering Research Laboratory (CERL)

2902 Newmark Drive

Champaign, IL 61824

\section{SPONSORING / MONITORING AGENCY NAME(S) AND ADDRESS(ES)}

U.S. Army Engineer Research and Development Center (ERDC)

Environmental Laboratory (EL)

3909 Halls Ferry Road

Vicksburg, MS 39180-6199

\section{DISTRIBUTION / AVAILABILITY STATEMENT}

Approved for public release; distribution is unlimited.

\section{SUPPLEMENTARY NOTES}

\section{ABSTRACT}

Zebra mussels (Dreissena polymorpha) are invasive/nuisance species first introduced into the Great Lakes region in the late 1980s. Since their introduction efforts have been underway to prevent and/or control their spread. Zebra mussel infestations can occur on submerged critical structure. For the U.S. Army Corps of Engineers (USACE) it is essential that hydraulic infrastructure are effectively and efficiently maintained to ensure proper water control and navigation. A study was conducted to determine the extent of the zebra mussel invasion on USACE districts and the impact zebra mussels have on USACE infrastructure. Consistent with available U.S. Geological Survey (USGS) data, it was found that zebra mussels are present within 24 of the 36 continental United States USACE district boundaries, although San Francisco and Galveston Districts have only isolated populations in non-USACE waters. Albuquerque and Omaha Districts appear to be the two districts most at risk for invasion. While infestations are common, $62 \%$ of the districts with USACE infested waters reported no or minimal impacts on the infrastructure or operation/maintenance costs. Those districts with impacts did not normally have cost figures readily available. It was also found that 12 districts have or have had zebra mussel monitoring programs in place.

\section{SUBJECT TERMS}

Zebra mussel, Introduced organisms, Nonindigenous aquatic pests, Hydraulic structures

\section{SECURITY CLASSIFICATION OF:}

a. REPORT
Unclassified

\section{b. ABSTRACT \\ Unclassified}

\begin{tabular}{c|c|c}
\hline 17. LIMITATION & $\begin{array}{c}\text { 18. NUMBER } \\
\text { OF ABSTRACT }\end{array}$ & 19 \\
OF PAGES & \\
\cline { 3 - 3 } SAR & 76 &
\end{tabular}

\section{c. THIS PAGE}

Unclassified 19a. NAME OF RESPONSIBLE PERSON

19b. TELEPHONE NUMBER (include area code) 